
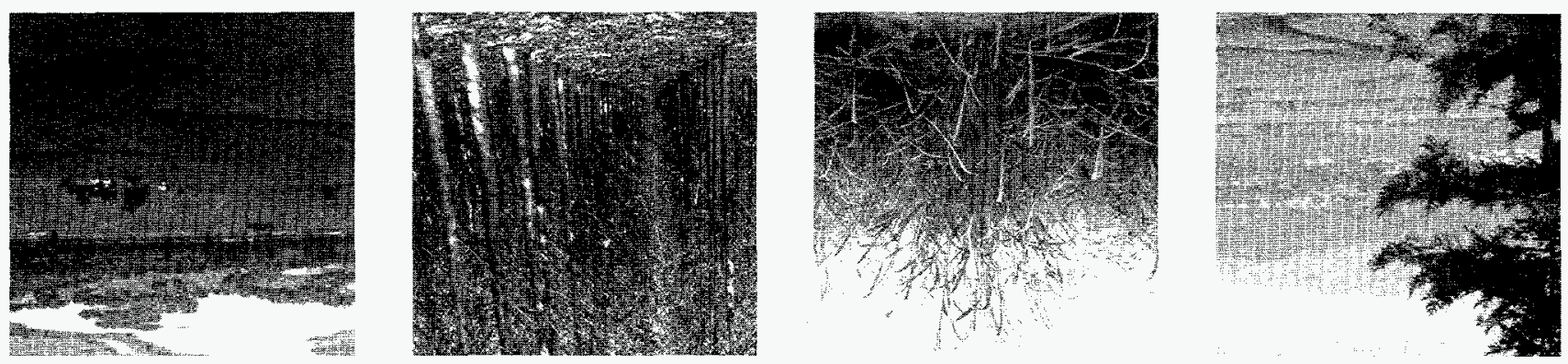

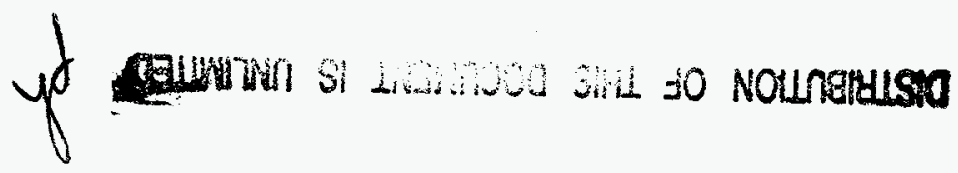

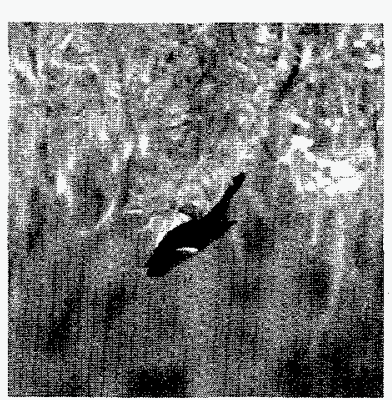

Y3ISHW

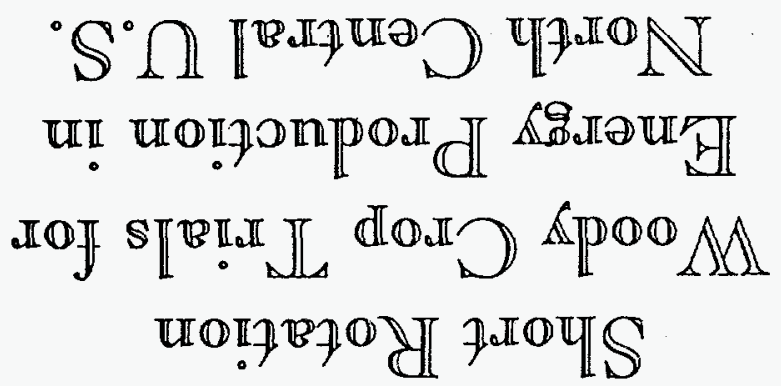

1150

904.2000

con

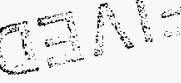
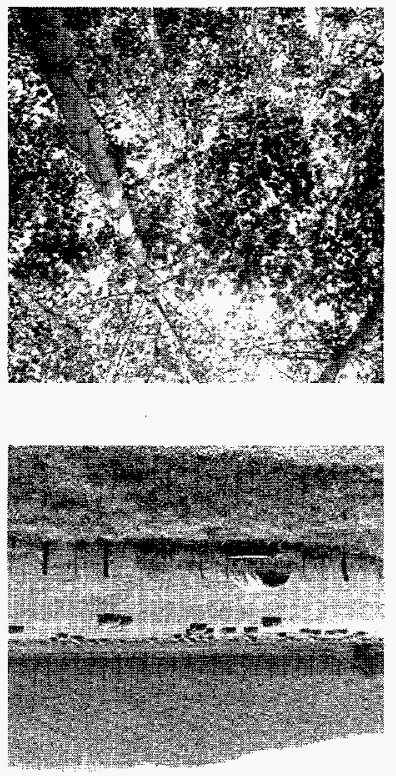

JpJa 
This report has been reproduced directly from the best available copy.

Available to DOE and DOE contractors from the Office of Scientific and Technical Information, P. O. Box 62, Oak Ridge, TN 37831 ; prices available from (423) 576-8401, FTS 626-8401.

Available to the public from the National Technical Information Service, U.S. Department of Commerce, 5285 Port Royal Road, Springfield, VA 22161.

This report was prepared as an account of work sponsored by an agency of the United States Government. Neither the United States Government nor any agency thereof, nor any of their employees, makes any warranty, express or implied, or assumes any legal liability or responsibility for the accuracy, completeness, or usefulness of any information, apparatus, product, or process disclosed, or represents that its use would not infringe privately owned rights. Reference herein to any specific commercial product, process, or service by trade name, trademark, manufacturer, or otherwise, does not necessarily constitute or imply its endorsement, recommendation, or favoring by the United States Government or any agency thereof. The views and opinions of authors expressed herein do not necessarily state or reflect those of the United States Government of any agency thereof. 


\title{
Short Rotation Woody Crop Trials for Energy Production in North Central U.S.
}

\author{
Edward Hansen \\ Daniel Netzer \\ Mike Ostry \\ David Tolsted \\ Kathy Ward \\ North Central Forest Experiment Station Forestry Sciences Laboratory \\ St. Paul, Minnesota
}

\author{
Prepared 1994 \\ Research supported by \\ Biofuels System Division \\ Office of Transportation Technologies \\ Activity No. EB 2413010 \\ for \\ Biofuels Feedstock Development Program \\ OAK RIDGE NATIONAL LABORATORY \\ Oak Ridge, Tennessee 37831-6422 \\ managed by \\ LOCKHEED MARTIN ENERGY RESEARCH CORP. \\ for the \\ U. S. DEPARTMENT OF ENERGY \\ under contract DE-AC05-960R22464
}

Additional support provided by

Energy Performance Systems, Minneapolis, Minnesota

Electric Power Research Institute, Pasadena, California 


\section{DISCLAIMER}

Portions of this document may be illegible in electronic image products. Images are produced from the best available original document. 
Abstract

Introduction -

objectives - -

Background _........ 3

Plantation design -..- 5

Format of report - 5

1994 results -

Biomass production - 7

Fertilization trials --

Clonal performance --

Summary for 1989-1995 - 12

Plantation maintenance labor and cost ---- 12

Biomass prediction equations _......... 14

Biomass production --_-_-_- 17

Tree mortality --

Tree mortality and biomass production ---- 19

Fertilization trials (effect on leaf $N$ ) --- 21

Fertilization trials (effect on tree growth) 23

Clonal performance ------ - - - -

Soil water - -

Soil carbon - - -

Plantation weed control - -

Genetic and pathogenic variability ---.---- 31

Increase resistance of a poplar clone ----- 32

Related research --_-_-

Conclusions -

Recommendations -

List of Publications - 


\section{LIST OF FIGURES}

Page

1. Plantation network

4

2. Planting design for a typical 10-acre plantation --_------- 6

3. Hybrid poplar plantation establishment and tending costs by year

4. Watertable depression under the Milaca plantation

5. Hybrid poplar height growth related to date of glyphosate application during the third growing season 


\section{LIST OF TABLES}

Page

1. Description of plantation sites - 3

2. Biomass production in 7- and 8-year-old plantations ------- 8

3. Leaf $\mathrm{N}$ concentration as influenced by year of fertilization- 10

4. Regression equation coefficients for the North Central U.S.

plantation network

5. Biomass production in 6- and 7-year-old plantations -------- 16

6. Mean annual biomass production by site and year of planting- 18

7. Tree mortality at the end of year 1 and year 8 for selected sites and clones -

8. Site and plot biomass adjusted for survival

9. Leaf nitrogen response in Milaca test

10. Tree growth $(\mathrm{dbh})$ response in Milaca fertilization test _- - 24

11. Ranking of 5- and 6-year-old clones - 


\section{APPENDICES}

A1 Establishment and Tending Costs for Two Sites

A2 Tree Dry-Weight Data set

A3 Number of Septoria Isolates Recovered From Each Host Species

A4 Number of Septoria Isolates Collected at Each Site

A5 Geographic Distribution of Septoria spp. Isolate Collection

A6 Growth by Diameter Class of 162 Septoria Isolates 13 Days After Inoculation

A7 Growth of 162 Septoria spp. Isolates Collected From Different Sites

A8 Growth of 162 Septoria spp. Isolates Collected From Various Populus Species and Hybrids

A9 Growth of 162 Septoria spp. Isolates Collected From Different Poplars

A10 Comparison of Pathogenicity of Different Septoria spp. Isolates Using a Leaf Disk Assay

A11 Stem Inoculation Assay for Pathogenicity

A12 Amplification and Analysis of DNA From Septoria musiva and $\underline{S}$. Populicola using the Polymerase Chain Reaction (PCR)

A13 Septoria Culture Collection as of March, 1995

A14 RAPD Analysis of $17 \underline{\text { S. }}$ musiva isolates

A15 Results of RAPD Analysis of Septoria Isolates

A16 Example of Results From Leaf Disk Bioassay for Septoria Leaf Spot Resistance of NE 308

A17 Leaf Disk Bioassay Results of Tissue Culture-Derived NE 308 Somaclones with Increased Septoria Leaf Spot Resistance

A18 Leaf Disk Bioassay Comparison

A19 NE 299 Somaclone Planting, Rosemount, Minnesota Ranked by Growth and Disease Resistance 


\section{ACRNOWLEDGMENTS}

Many individuals and organizations contributed to this program. Wendell Johnson (U. of Minn., Crookston) planted and provided annual measurements on several clonal trials in Minnesota including sites on a number of University of Minnesota Agricultural Experiment Stations. He also provided leadership with Tom Kroll (MN DNR) in establishing hybrid poplars on Conservation Reserve Program lands in Minnesota. U. of Minnesota (Crookston) provided partial funding for site tending one year and provided the major portion of funding for soil productivity studies. Rick Hall (Iowa State U.) and Bill Berguson (NRRI) established clonal trials and provided annual measurements. Jim Bockheim and Art Peterson (U. of Wisconsin) arranged clonal trial planting sites on U. of Wisconsin Agricultural Experiment Station Farms. Adrian Hagen (WI DNR) provided land and site preparation for a clonal trial. Planting stock for clonal trials was provided by Carl Mohn, U. of Minnesota ( $\underline{P}$. deltoides), Don Riemenschneider, NCFES ( $\underline{P}$. trichocarpa), Gary Wyckoff, Institute of Paper Chemistry (hybrid aspen), Rick Hall, Iowa State U. (Populus sp.) and John Preece, Southern Illinois U. (Acer saccharinum). Preparation of the economic information for the DOE database was performed by Mike Vasievich's staff (NCFES). Soil productivity research was lead by Bill Berguson. 


\section{ABSTRACT}

Tree plantations at several sites have numerous clones with heights greater than 45 feet and diameters of $6+$ inches in eight years. $A$ number of clones in associated small-plot hybrid trials have even better growth than the commercially available clones planted in large blocks at the same sites. The fastest growth rates have been attained in a plantation on a wet site at Milaca, MN, a plantation at Granite Falls, WI, and a plantation at Mondovi, WI, where the largest trees are up to 8 inches $\mathrm{DBH}$ at age 8 . Mean annual production averages 3 dry tons per acre per year for the 5 best clones over all the test sites, and is still increasing. Mean annual production ranges from 4 to 5+ dry tons per acre in the best clonal blocks, and up to 8.1 tons per acre for the best new hybrids being tested in small-plot trials. The small-plot hybrid trial data indicate potential future biomass increases as new clones are introduced into commercial plantings. Reduced growth at some sites was related primarily to insufficient soil water during the growing season, and susceptibility to the disease Septoria musiva. Most tree mortality ( 36 percent) occurred during the establishment year with only an additional 2 percent mortality over the next 7 years. Leaf tissue nitrogen (N) levels decreased as trees aged and approached the hypothesized 3 percent critical level as trees reached 5- and 6-years old. Fertilization at 75 and 150 lbs/acre $N$ resulted in significant increases in leaf tissue $\mathrm{N}$ both in extensive trials replicated across the plantation network and in an designed fertilizer trial at Milaca that was replicated over years. However, no significant increase in tree growth has been detected. There are significant clonal differences in leaf tissue nitrogen. Hybrid poplar plantations planted on agricultural fields produce significant increases in soil carbon, although there may be carbon loss during the early years of plantation establishment. Septoria musiva is the major pathogen affecting survival and growth of hybrid poplar plantations. A collection of 859 Septoria musiva and Septoria populicola isolates has shown considerable variability in the microorganism. Inoculation tests indicate that host specificity may need to be considered when screening clones for resistance. Tissue culture techniques are being used to increase resistance to septoria in clone NE-308. The tissue culture procedure has been optimized for that clone and over 200 generation "2" plants are ready for field testing in 1995 . 


\section{INTRODUCTION}

\section{Objectives:}

The primary objective of this energy plantation program is to acquire information essential for establishing commercial short rotation fuelwood plantations in the north central region of the U.S. The focus of this effort is a plantation network across the north central states designed to provide improved measures of potential commercial biomass yield in this region, and to determine costs of wood energy from short-rotation woody crop (SRWC) plantations. The establishment of these large-size SRWC plantations in cooperation with an industrial user facilitates transfer of research expertise to the private sector and permits identification of operational problems that may require further research.

The objective of the biomass component is to determine commercially attainable biomass yields given the best site tending possible under the constraints of this extensive plantation network. Biomass yields were obtained for the current best clones at each of 8 sites to identify clones and sites that have the greatest yield. Analysis of the entire data set provides information on biomass yield potential across the region and provides clues regarding site parameters related to high yields.

Additional research objectives were incorporated into the program to advance the many elements of the program at about the same rate so that critical areas were not ignored. These additional areas of research have been underway for various periods of time and include identification of new faster-growing hybrids in clonal trials, developing improved weed control strategies, monitoring plantation nitrogen status with a leaf tissue bioassay, conducting nitrogen fertilization trials, determining if there is measurable soil carbon sequestration under older hybrid poplar plantations, developing a Septoria resistant "model" clone, and acquiring a better understanding of the septoria pathogen for developing improved nursery screening techniques for new clonal material from the breeding program.

One of the primary limiting factors in the development of an efficient, reliable system using hybrid poplars for energy and fiber production is the high disease susceptibility of many clones that have been planted and tested. Chemical and cultural controls have been researched and tried operationally with varying degrees of success. Considering environmental variables, economics, and safety, genetic resistance is the most promising strategy to employ to minimize damage caused by disease. However, it must be remembered that the threat of disease outbreaks is always present owing to the ability of microorganisms to rapidly adapt to their hosts and evolve into more pathogenic strains. No matter what disease control strategies are used, constant vigilance against new pest populations, and a sustained effort in tree improvement will be needed to ensure continued success. 
Hybrid poplars are subjected to many microorganisms which, under some environmental conditions, can cause disease to develop. Poplars are fast growing and have a wide geographic range, and are thus being considered for biomass plantings in many diverse areas. Microbe populations may be quite different from one region of the country to another, so poplar clones will need resistance to a large number of pathogens. Adding to this complexity is the presence of many species, races, biotypes, and strains of some genera of important poplar pathogens.

The two task activities related to protection funded under this agreement were to 1 ) examine the population of $\underline{S}$. musiva to determine how variable this pathogen was in terms of causing disease and 2) apply somaclonal selection techniques to a selected poplar clone to increase resistance in that clone to $\underline{\mathrm{S}}$. musiva.

\section{Background :}

A network of research and demonstration energy plantations was established in 1987 and 1988 across a 4-state region in the north central U.S. (Figure 1). The primary criteria in site selection were: 1) the sites are within the region from the eastern edge of the Dakotas into western Wisconsin, 2) each site consisted of agricultural cropland with a single soil type, and 3) soil types were those occurring on large acreage in the region (see Table 1 for general site characteristics). This energy plantation network was cooperatively supported by the North Central Forest Experiment Station (USDA), the Oak Ridge National Laboratory (DOE), Energy Performance systems Inc., and the Electric Power Research Institute. Approximately 130 acres out of the original planted 400 acres still remain in the program in 1995 despite loss of some sites from the historic drought in 1988 and 1989 and the loss of substantial acreage when some farmer participants withdrew from the program when changes in program sponsorship resulted in tardy land rent payments. Biomass production, tree survival, and data from supporting studies have been collected annually through the 1994 growing season and are summarized in this report.

Table 1. Description of Plantation Sites

\begin{tabular}{cllllcr} 
State & County & Town & Soil Series & Texture & CER $^{1}$ acres \\
\hline MN & Martin & Fairmont & Coland & clay loam & 62 & 10 \\
MN & Chippewa & Granite Falls & Dupage & loam & & 15 \\
MN & Mille Lacs & Milaca & Milaca & silt clay & 42 & 14 \\
MN & Carlton & Cloquet & Ahmeek & loam & 42 & 10 \\
ND & Cass & Fargo & Fargo & silt clay & 67 & 20 \\
SD & Minnehaha & Sioux Falls & Kranzburg & silt/c/loam & 70 & 16 \\
WI & Buffalo & Mondovi & Antigo & silt loam & 50 & 16 \\
WI & Ashland & Ashland & Ontonagon & silt clay & 35 & 20
\end{tabular}

${ }^{1}$ Crop Equivalency Ratio 


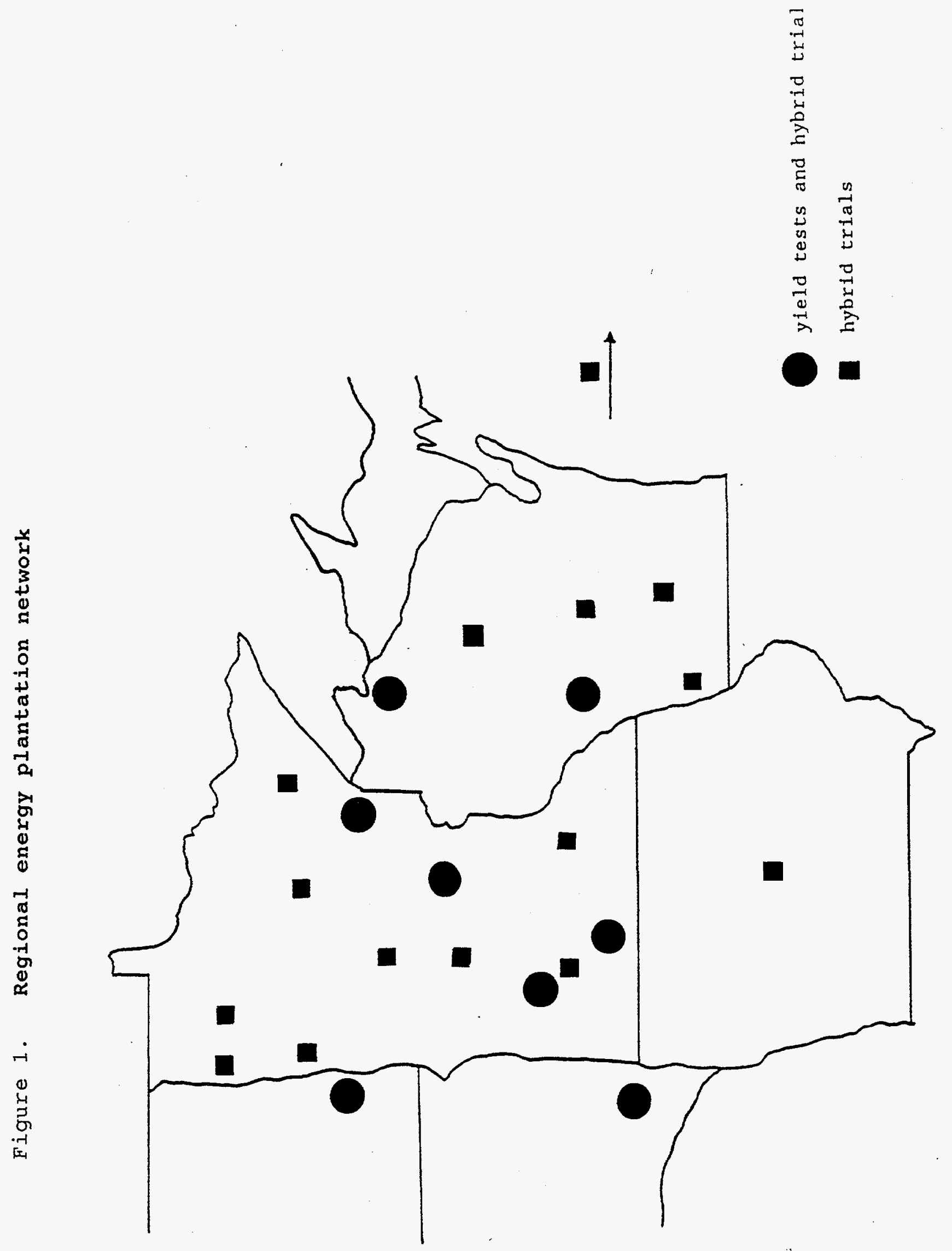




\section{Plantation design:}

The basic planting design for the plantations is shown in Figure 2 . Trees in all plantations were hand planted at an $8 \times 8$ foot spacing chosen to achieve maximum mean annual biomass production with an estimated rotation of 10 years. The 10 -acre plantations were subdivided into 10 smaller monoclonal blocks with a different hybrid planted in each block to increase the probability of having one or more superior growing clones at each site. Each monoclonal block has an area of 0.8 acres. This block size is adequate to obtain valid biomass yield data, conduct soil-tree growth investigations, observe disease incidence, and eventually conduct harvesting trials. Three permanent 25-tree plots were established in each monoclonal block. Trees in these plots were remeasured annually to determine biomass production and tree mortality. Cultural operations on the entire 10-acre plantation were recorded to determine labor and cost inputs for evaluation of SRIC economics.

Hybrid trials were also planted using an identical planting design for all sites in a particular year, but a re-randomization of clonal plots each succeeding year. A different number of hybrids were planted each year; 79 in 1987, 67 in 1988, 49 in 1989, 42 in 1990, 56 in 1991, 44 in 1992, and 81 in 1993. Tentative selections of the best growing hybrids in the region are made each year to include in the following year's trial along with promising new material. These trials permit identification of better hybrids for future large-scale plantations.

\section{Report format:}

This report first summarizes results of the 1994 growing season, and then sumarizes general findings over the eight-year period of investigation. Selected data sets that may be of use by others, but have not been previously published, are included in their entirety. Published subjects are briefly summarized and referenced to the publication. Other subjects that are unpublished, or have recently collected unpublished data are given a more detailed description of design, analysis and interpretation. 
Figure 2. Planting design for typical 10-acre plantation

GRAVEL ROAD
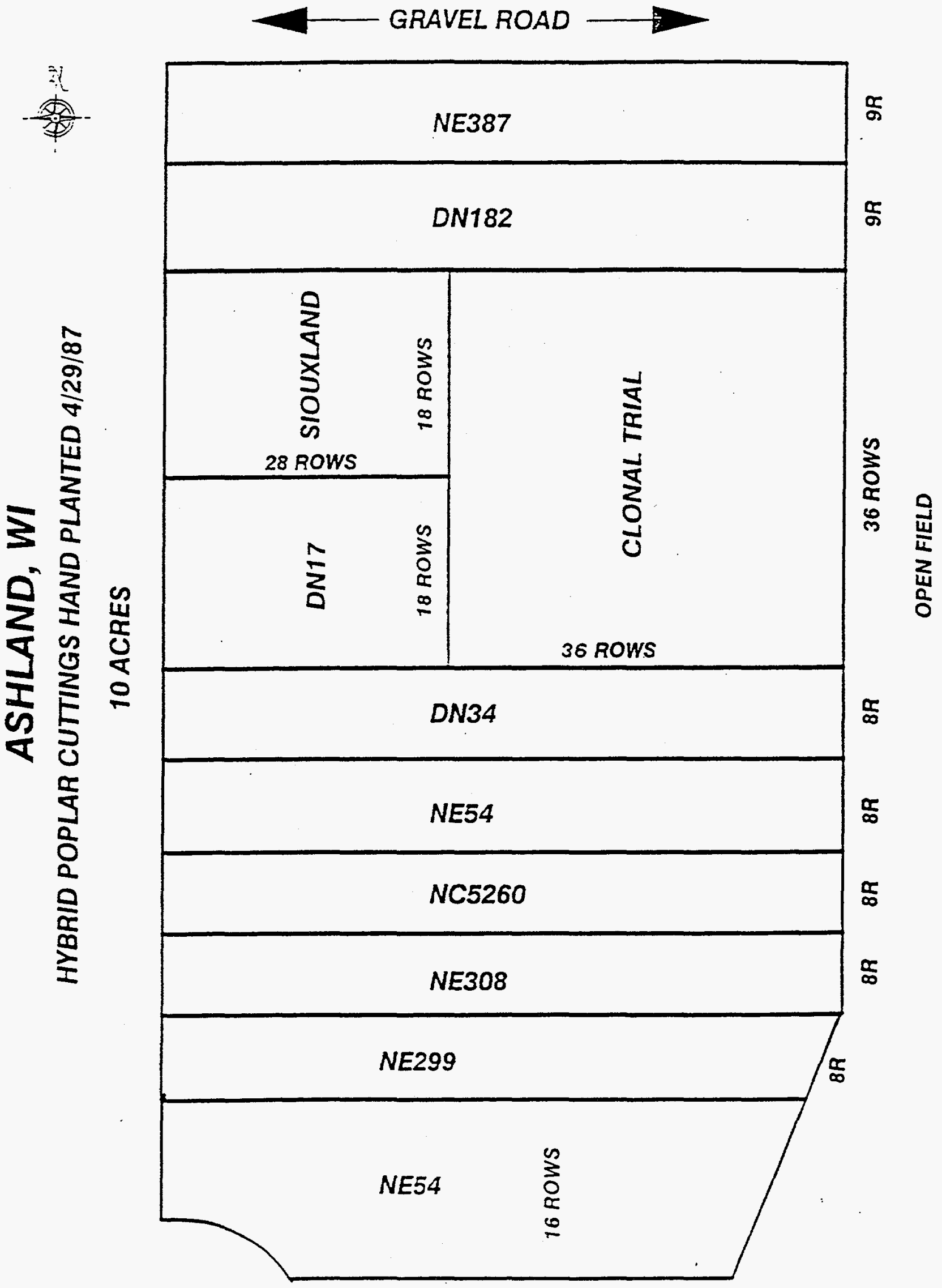
1994 RESULTS

\section{Biomass:}

Measurements of tree survival and dbh are collected each fall on the better clones at all sites. Periodically, selected trees are harvested, weighed green, subsampled and oven dried to determine total tree dry weight. Using these dried tree weight data, biomass regression equations of the form "Tree weight $=a+b \mathrm{DBH}^{2}$ " were developed to predict biomass production in the plantations. Equations were developed for each site for which there were sufficient trees to warrant doing so ( $n>20)$, which included Ashland, Mondovi, Granite Falls, and Milaca. For the remaining sites, a generalized regression equation developed from all the tree dry weight data from all sites $(n=136)$ was used to calculate biomass production.

Biomass production in the 7 - and 8-year-old plantations in the fall of 1994 ranged up to 5.3 dry tons/acre/year (TAY) (Table 2). Biomass yields of many plots are within the range first projected (3-6 TAY), and are still increasing through the 1994 growing season. Average biomass production for the two age-groups of plantation show 0.27 TAY (10\%) more biomass in the younger 7-year-old plantations. The greater yields in the younger plantations are believed due to better survival during establishment, and to better first-year tending. Biomass production exceeds $4 \mathrm{TAY}$ in six clonal block plantings; all of which are in seven-year-old plantations located at the two sites of Granite Falls and Mondovi (Table 2a). In addition, biomass production exceeds 3 TAY in many blocks scattered across most of the sites. 
Table 2. Biomass production in 7-and 8-year-old plantations in fall of 1994 (actual standing biomass; oven-dry). Calculated from site-specific regression equations. $\mathrm{X} 1$ is the mean of specific clones (DN-17, DN-34, DN-182, NE-308 or Siouxland) over all sites; $\mathrm{X} 2$ is the mean of all those clones within a given site. (-) indicates biomass declined since 1993.

Table 2a. 7-year-old plantations.

\begin{tabular}{|c|c|c|c|c|c|c|c|}
\hline \multirow{3}{*}{ CLONE } & \multicolumn{5}{|c|}{ SITE } & \multirow[b]{2}{*}{ SXF } & \multirow[b]{2}{*}{$\overline{\mathrm{x}} 1$} \\
\hline & $\mathrm{ASH}$ & CLO & FAI & GRF & MON & & \\
\hline & $\begin{array}{c}----- \\
*\end{array}$ & $*$ & $\underset{*}{\operatorname{tons} /}$ & te/ye & $*$ & * & \\
\hline $\mathrm{DN}-17$ & 1.7 & 0 & 2.8 & 4.6 & 3.0 & 2.0 & 2.82 \\
\hline$N E-19$ & $*$ & 0 & $*$ & 5.3 & 0 & 0 & \\
\hline $\mathrm{DN}-34$ & $2.4-$ & 2.1 & 3.4 & 4.1 & $4.7-$ & 3.0 & 3.28 \\
\hline $\mathrm{NE}-54$ & 1.9 & 0 & 0 & - & 0 & - & \\
\hline $\mathrm{DN}-182$ & 2.3 & 2.3 & 3.5 & 4.0 & 4.2 & 2.3 & 3.10 \\
\hline $\mathrm{NE}-299$ & 2.7 & 0 & 0 & - & 0 & - & \\
\hline $\mathrm{NE}-308$ & 1.9 & 3.1 & $2.7-$ & $3.7-$ & 3.1 & 2.5 & 2.75 \\
\hline$N E-387$ & 1.9 & 0 & 0 & - & 0 & - & \\
\hline SIOUX & $2.4-$ & 0 & $2.4-$ & 2.9 & * & $2.5-$ & 2.55 \\
\hline $\mathrm{NC}-5260$ & 0 & 0 & 0 & - & 2.7 & 0 & \\
\hline $\bar{x} 2=$ & 2.1 & 2.5 & 3.0 & 3.9 & 3.8 & 2.4 & 2.9 \\
\hline
\end{tabular}

Table 2b. 8-year-old plantations.

\begin{tabular}{|c|c|c|c|c|c|c|c|}
\hline \multirow{3}{*}{ CLONE } & \multicolumn{6}{|c|}{ SITE } & \multirow[b]{2}{*}{$\bar{X} 1$} \\
\hline & ASH & FAR & GRF & MIL & MON & SXF & \\
\hline & ----- & $--\infty$ & tons/ & $\mathrm{re} / \mathrm{ye}$ & ---- & --- & \\
\hline $\mathrm{DN}-1$ & * & * & 3.0 & $*$ & $*$ & * & \\
\hline $\mathrm{DN}-17$ & 2.3 & 3.2 & 3.6 & 3.9 & $3.8-$ & 2.6 & 3.23 \\
\hline $\mathrm{NE}-19$ & $*$ & 0 & $*$ & * & * & $*$ & \\
\hline $\mathrm{DN}-34$ & 1.1 & 0 & 3.7 & 2.6 & 3.3 & 1.8 & 2.50 \\
\hline $\mathrm{NE}-41$ & $\star$ & * & * & 0 & $*$ & 0 & \\
\hline$N E-47$ & * & * & * & * & 0 & $*$ & \\
\hline$N E-54$ & 0 & 0 & 0 & 0 & 0 & 0 & \\
\hline $\mathrm{DN}-182$ & 1.3 & 3.0 & + & 3.5 & $3.9-$ & 2.4 & 2.82 \\
\hline $\mathrm{NE}-299$ & 2.4 & 0 & 0 & 0 & 0 & 0 & \\
\hline $\mathrm{NE}-308$ & $2.0-$ & 0 & 2.7 & 3.1 & $2.4-$ & 2.8 & 2.60 \\
\hline$N E-387$ & 1.6 & 0 & + & 0 & 0 & 0 & \\
\hline SIOUX & 0.9 & 2.6 & 2.3 & 3.1 & 2.7 & 1.5 & 2.18 \\
\hline$N C-5260$ & 1.2 & 0 & 1.9 & 2.2 & 2.1 & 1.8 & \\
\hline $\bar{x} 2=$ & 1.5 & 2.9 & 3.1 & 3.2 & 3.2 & 2.2 & $\longdiv { 2 . 6 8 }$ \\
\hline
\end{tabular}

* Clone not planted.

0 Measurements terminated because of poor growth.

+ Clone removed for road construction. 
Fertilization trials:

Beginning in 1990, leaf samples were collected annually in early July at each site from three clones (DN17, DN34, and DN182), and analyzed for nitrogen (N) concentration. In 1992 and 1993, following leaf sample collection, one of the three biomass measurement plots in each clonal block was randomly selected and fertilized with 150 lbs nitrogen (different plots each year), leaf samples collected again 3 weeks later from both fertilized and unfertilized plots, and then annually thereafter. Tests were made by ANOVA for significant differences in leaf nitrogen between the fertilized plots and the unfertilized control plots.

Plots throughout the region (both fertilized and unfertilized), showed much lower leaf $\mathrm{N}$ in 1994 as compared to 1993. Site averages ranged from only $2.3-2.98$ in 1994 vs $3.0-3.8 \%$ in 1993 (exceptions were Fargo at 2.3\% in 1993 and Fairmont at 3.3\% in 1994). Leaf $N$ in 1994 was significantly higher $(p=0.02)$ from plots fertilized in 1993 than from the unfertilized control plots (Table 3 ). However, there was no significant difference in 1994 leaf $N$ between 1992 fertilized and control plots. These results suggest that the fertilization effect of increased leaf $\mathrm{N}$ lasts only one year.

Fertilization did not result in increased tree growth as measured at DBH. Comparison of changes in mean tree diameter between fertilized and unfertilized plots showed no significant differences when analyzed by regression for either the 1992-1993 or the 1993-1994 growing period for the 1992 fertilization, the 1993-1994 growing period for the 1993 fertilization, or for the entire period of record (1991-1994) for either fertilization date.

A replicated fertilizer trial was conducted at Milaca, one of the sites shown in Figure 1. Three of 9 replicated plots were randomly selected in 1992 (plantation age was 4 years old) and treatments of 0 , 75 , and 150 lbs/acre $\mathrm{N}$ applied. Three more plots were selected randomly in 1993 and 1994 and the treatments repeated. Both the 75 and 150 lbs/acre of $\mathrm{N}$ fertilization treatments in 1994 (below) showed significant increases in leaf $\mathrm{N}$ relative to the control plots.

$\begin{array}{lcc} & \text { pre-fertilization post-fertilization } \\ & --1 & \text { pot means }(8 \mathrm{~N}) \\ \text { control } & 2.4 & 2.7 \\ 75 \text { lbs N } & 2.3 & 3.5 \\ 150 \text { lbs N } & 2.3 & 3.6\end{array}$

The data are the average of 3 leaf samples from each of 12 trees per plot. There are 12 clones per plot, one tree of each clone. A regression analysis of treatment effect using individual trees as the sample (Leaf $\mathrm{N} f$ treatment + clone) showed a borderline significant difference between treatments PRIOR TO nitrogen fertilization $(p=0.049)$, but a highly significant differences between treatments following fertilization $(p=0.000)$. Also, an analysis of the CHANGE IN 
Table 3. Leaf $\mathbf{N}$ concentration as influenced by year of fertilization.

\begin{tabular}{|c|c|c|c|c|}
\hline & & 1994 & ceat $N$ Con & \\
\hline Site & Clone & Control & Fert 1992 & Fert 1993 \\
\hline Ashland & $\begin{array}{l}\text { DN17 } \\
\text { DN } 34 \\
\text { DN18 }\end{array}$ & $\begin{array}{l}2.43 \\
2.19 \\
2.19\end{array}$ & $\begin{array}{l}2.26 \\
2.41 \\
2.35\end{array}$ & $\begin{array}{l}-\overline{4} \\
2.41 \\
2.42\end{array}$ \\
\hline Cloquet & $\begin{array}{l}\text { DN34 } \\
\text { DN182 }\end{array}$ & $\begin{array}{l}2.35 \\
2.20\end{array}$ & $\begin{array}{l}2.85 \\
2.72\end{array}$ & $\begin{array}{l}2.85 \\
2.97\end{array}$ \\
\hline Fairmont & $\begin{array}{l}\text { DN17 } \\
\text { DN34 } \\
\text { DN182 }\end{array}$ & $\begin{array}{l}3.11 \\
3.30 \\
3.57\end{array}$ & $\begin{array}{l}3.15 \\
3.13 \\
3.45\end{array}$ & $\begin{array}{l}3.34 \\
3.51 \\
3.34\end{array}$ \\
\hline Fargo & $\begin{array}{l}\text { DN17 } \\
\text { DN182 }\end{array}$ & $\begin{array}{l}2.63 \\
2.20\end{array}$ & $\begin{array}{l}1.88 \\
2.74\end{array}$ & -- \\
\hline Granite Falls & $\begin{array}{l}\text { DN17 } \\
\text { DN34 }\end{array}$ & $\begin{array}{l}2.94 \\
2.78\end{array}$ & $\begin{array}{l}2.84 \\
2.91\end{array}$ & $\begin{array}{l}-- \\
--\end{array}$ \\
\hline Milaca & $\begin{array}{l}\text { DN17 } \\
\text { DN34 } \\
\text { DN182 }\end{array}$ & $\begin{array}{l}2.37 \\
2.55 \\
2.35\end{array}$ & $\begin{array}{l}2.68 \\
2.50 \\
2.23\end{array}$ & $\begin{array}{c}2.29 \\
-- \\
2.78\end{array}$ \\
\hline Mondovi & $\begin{array}{l}\text { DN17 } \\
\text { DN34 } \\
\text { DN182 }\end{array}$ & $\begin{array}{l}3.07 * \\
3.10 * \\
2.49 *\end{array}$ & $\begin{array}{l}2.94 \\
2.64 \\
2.88\end{array}$ & $\begin{array}{c}3.13 \\
-- \\
--\end{array}$ \\
\hline Sioux Falls & $\begin{array}{l}\text { DN17 } \\
\text { DN34 } \\
\text { DN182 }\end{array}$ & $\begin{array}{l}2.79 \\
2.77 \\
2.54 \\
\end{array}$ & $\begin{array}{l}2.90 \\
2.87 \\
2.57 \\
\end{array}$ & $\begin{array}{l}2.83 \\
2.91 \\
2.72 \\
\end{array}$ \\
\hline & $\bar{x}$ & 2.68 & 2.68 & $2.88 * *$ \\
\hline
\end{tabular}

* Control data are relatively high because the entire plantation was fertilized in August 1991.

** Significantly different from the unfertilized controls 
leaf $N$ (pretreatment - post-treatment) showed a highly significant difference between treatments $(p=0.000)$. However, these analyses are weak because there is no randomization of treatments with this single year analysis. The results of a multi-year analysis (with replication and randomization) will be presented later in the summary section.

The effect of nitrogen fertilization on tree diameter was mixed. Based on an analysis with tree as the sample (no randomization), the plots receiving the 1992 fertilization treatment showed no significant growth response in either 1992 or 1993. On the other hand, the 1993 fertilization treatment showed a highly significant effect in 1994 . However, this latter result is suspect since the control plot was lagging progressively behind the treatment plots even before the treatment was applied. A more complete analysis involving the entire data set is described in the summary section.

\section{Clonal performance:}

Analysis of clonal effect on leaf $\mathrm{N}$ in the Milaca test was done by pooling all treatments into pre- and post-fertilization groups. Results showed that there was a highly significant difference between clones in leaf $\mathrm{N}$ prior to fertilization, but no significant difference after fertilization. This suggests that leaf $N$ concentration differs between clones under limiting nutrient conditions, but tends to be similar between clones under conditions of luxury consumption.

Analysis of clonal growth differences in the Milaca test (all treatments pooled) shows highly significant differences as follows:

\begin{tabular}{|c|c|c|}
\hline Clone & $\frac{\mathrm{Dbh}}{(\mathrm{mm})}$ & \\
\hline NM6 & 143 & $a * *$ \\
\hline DN131 & 122 & b \\
\hline I $45 / 51$ & 117 & $\mathrm{~b}$ \\
\hline DN55 & 100 & C \\
\hline *DN182 & 98 & c \\
\hline * S IOUX & 98 & C \\
\hline *NE308 & 92 & $\mathrm{~cd}$ \\
\hline *DN34 & 88 & cde \\
\hline *DN17 & 88 & cde \\
\hline NE20 & 76 & de \\
\hline NE387 & 7 & \\
\hline NC5 260 & 71 & \\
\hline
\end{tabular}

* Clones in regional monoclonal block trials.

** Clones followed by same letter are not significantly different.

Note that one clone is performing as well, and three clones are performing significantly better than the five best clones in the monoclonal block trials (the present commercially available clones in the region). 
SUMMARY FOR 1989-1994

\section{Plantation maintenance labor and cost:}

Detailed cost records were kept for two sites in the regional trial network (Appendix A). The sites were Ashland, WI, and Sioux Falls, SD. Ashland is one of the northern sites in a marginal farming area in northwestern Wisconsin. Sioux Falls is one of the southern sites located on productive farmland in eastern South Dakota that has a cropping history of small grain and corn production. Each site has weed problems unique to the location which require different management strategies. At Ashland perennial grasses, mainly quackgrass (Agropyron repens, I.), were most common. These perennial grasses were controlled with grass herbicides such as fluazifop during the growing season or glyphosate when the trees were dormant. At Sioux Falls, on the other hand, broadleaf annual weeds such as redroot pigweed (Amaranthus retroflexus, L.) were the main weeds competing with the hybrid poplar. Mechanical cultivation was used to control these weeds since herbicides for broadleaf weed control also damage the trees. In some cases where mechanical cultivators could not get close enough to the trees without damaging the roots, the weeds were controlled by hand weeding. In addition, tractor access into the plantation was more limited at Ashland due to the clay soils which prohibited tillage during wet periods.

Costs through year eight are illustrated in Figure 3. At Sioux Falls total cost was $\$ 656.10$ per acre compared with a total cost per acre at Ashland of $\$ 468.98$. Establishment and tending costs in the first year represent approximately one-half of the total costs for each site. Equipment and labor costs at Sioux Falls were $\$ 358.70$ and materials cost $\$ 300.40$. This compares to equipment and labor costs of $\$ 201.54$ and materials cost of $\$ 267.44$ at Ashland. At Sioux Falls materials cost less than labor and equipment, reflecting the greater availability of chemicals and other farm materials in this agricultural area. Ashland, on the other hand had a higher cost for materials compared to labor reflecting the difficulty in obtaining farm chemicals in this marginal farming area. In addition, the more persistent weeds especially from broadleaf weeds at Sioux Falls required greater use of mechanical and hand labor for control. Noxious weed control, especially thistle, also required additional efforts to control. Actual labor costs were recorded for all contract operations. When the operations were performed by USDA staff the recorded cost was obtained from the custom rate guides published by state agencies for agricultural operations. The cost of chemical weed control (simazine) in year three at Sioux Falls and year four at Ashland will likely be greatly reduced in future plantations. Cost of simazine was approximately ten times higher than the chemicals such as sulfometuron that will likely replace it. There were no tending costs in year eight. Cost of operations discussed here are typical of the costs likely incurred through year three or four with the exception of the cost of simazine. Costs beyond year four will likely not be 


\section{FIGURE 3 HYBRID POPLAR PLANTATION}

ESTABLISHMENT AND TENDING COSTS BY YEAR.

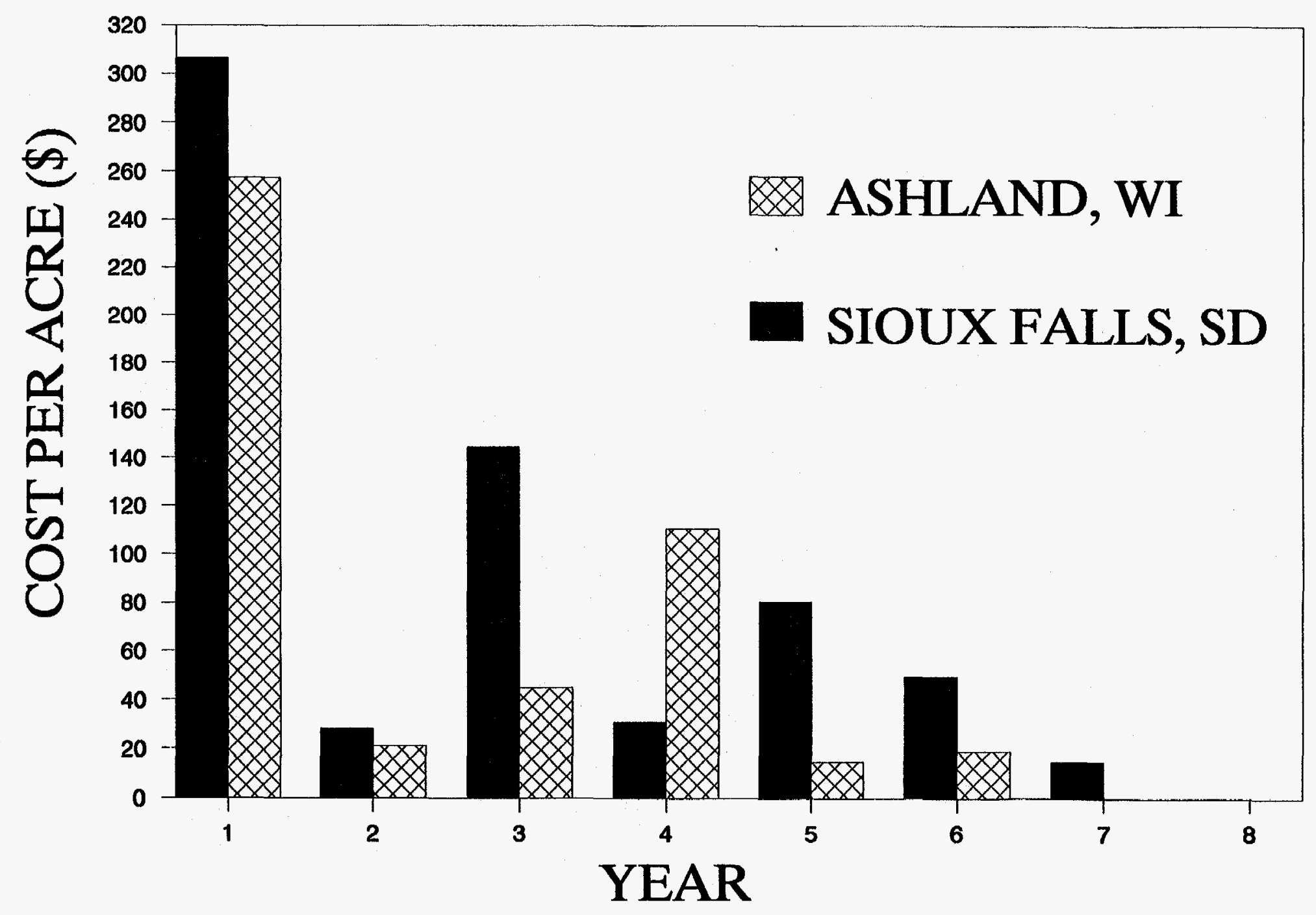


necessary in commercial operations unless noxious weed control is required by local ordnance. The best clones selected from this research, when planted in large blocks, will have canopy closure sooner than these test plantations that contained both good and poor clones. Earlier canopy closure will result in reduced costs over those reported here.

\section{Biomass prediction equations}

Previously reported biomass estimates were based on a prediction equation of the form "Logetree dry weight $=a+b \log _{e} \mathrm{DBH}$ ". This equation fit reasonably well until 1994. With the addition of tree dry weight data for larger trees, this equation form under-predicted the dry weight of larger sized trees, resulting in an under-estimate of biomass on some sites. Consequently, different equation forms were tried, and the form "tree dry weight $=a+b \mathrm{DBH}^{2}$ " was selected as a good predictor and with the residuals showing little bias. Tree diameters and weights for the dry-weight data set ranged from 1- to $20-\mathrm{cm}$ and .5- to 93-kg respectively (Appendix A2).

Regression equations were derived for each site and clone (Table 4 ). Although there were no significant differences in variance or slope between equations, the Milaca site regression tended to differ slightly from the other sites (trees weighed less for a given dbh). Including the Milaca tree dry weight data in a pooled data set resulted in lowering the biomass estimates for all sites, except Milaca which was increased. Consequently, site-specific biomass regression equations were derived for all sites for which there were sufficient tree dry weight data. These site-specific regressions resulted in higher biomass estimates for Ashland, Granite Falls, Mondovi and lower estimates for Milaca. Biomass estimates for the remaining sites were calculated using the generalized regression equation (all tree dry weight data pooled). Use of the site specific equations as compared to the generalized regression equation resulted in an overall increase in biomass prediction of 3 percent for the plantation network, and a maximum of 8 percent for a single site (Granite Falls 1988 planting). Milaca declined 6 percent.

Since the new site-specific equations based on $\mathrm{DBH}^{2}$ fit the data significantly better, and no trees had been harvested in 1993 with which to modify the equations, the newly derived equations were used to recalculate the 1993 biomass estimates. These revised estimates are shown in Table 5. Biomass calculated with the new equations increased 23 percent for the 6-year-old plantations, and 13 percent for the 7-year-old plantations over that reported in the $1993^{\mathrm{DOE}}$ Annual Report.

Another possible source of error in addition to the goodness of fit of the regression equations, is the accuracy at which the subsampling procedure provides an unbiased estimate of the total tree dry weight. 
A limited test was conducted on one tree with a dbh of $16.7 \mathrm{~cm}$, where in addition to subsampling in the usual manner, the entire tree was dried and weighed. The subsample over-estimated total tree dry weight by 1.5 percent.

Table 4. Regression equation coefficients for the North Central U.S. plantation network. (Tree weight $=a+b^{2} B^{2}$ )

Equation

General equation

by site:

Ashland, WI

Mondovi, WI

Granite Falls, MN

Milaca, MN

Milaca, MN (NE clones)

Fairmont, MN

by clone:

DN34

DN17

DN182

NE308

NE5 4 /NE 387

Siouxland

$\begin{array}{rccc}\underline{a} & \underline{b} & \underline{\underline{\underline{I}}^{2}} & \underline{\underline{n}} \\ -1.67 & .231 & 98.5 & 136 \\ & & & \\ .60 & .208 & 98.5 & 34 \\ -3.56 & .255 & 99.0 & 27 \\ -2.12 & .249 & 99.7 & 24 \\ -3.16 & .226 & 97.1 & 24 \\ -.04 & .206 & 93.5 & 13 \\ .96 & .199 & 92.7 & 8 \\ & & & \\ -2.22 & .243 & 98.6 & 34 \\ -1.10 & .230 & 98.2 & 34 \\ -1.08 & .223 & 98.1 & 25 \\ -.51 & .190 & 91.3 & 21 \\ -.04 & .206 & 93.5 & 13 \\ .96 & .199 & 92.7 & 8\end{array}$

25

21

8 
Table 5. Biomass production in 6- and 7-year-old plantations in fall of 1993 (actual standing biomass; oven-dry). Calculated from site-specific regression equations. $\mathrm{X} 1$ is the mean of specific clones (DN-17, DN-34, DN-182, $\mathrm{NE}-308$ or Siouxland) across all sites, and $\overline{\mathrm{X}} 2$ is the mean of all those clones within a given site.

Table 5a. 6-year-old plantations.

\begin{tabular}{|c|c|c|c|c|c|c|c|}
\hline \multirow[b]{2}{*}{ CLONE } & \multicolumn{7}{|c|}{ SITE } \\
\hline & ASH & CLO & FAI & GRF & MON & SXF & $\overline{\mathrm{X}} 1$ \\
\hline$D N-1$ & $\begin{array}{c}* \\
*\end{array}$ & $*$ & $\begin{array}{c}\text { tons } \\
*\end{array}$ & $c e / y$ & 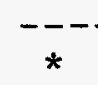 & $*$ & \\
\hline $\mathrm{DN}-17$ & 1.6 & 0 & 2.7 & 4.5 & 3.0 & 1.8 & 2.72 \\
\hline$N E-19$ & $*$ & 0 & * & 5.2 & 0 & 0 & \\
\hline$D N-34$ & 2.5 & 1.7 & 3.2 & 3.9 & 4.8 & 2.8 & 3.15 \\
\hline$N E-54$ & 1.6 & 0 & 0 & 0 & 0 & 0 & \\
\hline$D N-182$ & 2.3 & 2.0 & 3.5 & 3.8 & 4.2 & 2.2 & 3.00 \\
\hline NE-299 & 2.4 & 0 & 0 & 0 & 0 & 0 & \\
\hline$N E-308$ & 1.9 & 2.7 & 3.0 & 3.9 & 3.1 & 1.8 & 2.73 \\
\hline $\mathrm{NE}-387$ & 0 & 0 & 0 & 0 & 0 & 0 & \\
\hline SIOUX & 2.5 & 0 & 2.5 & 2.8 & $*$ & 2.6 & 2.60 \\
\hline $\mathrm{NC}-5260$ & 0 & 0 & 0 & 0 & 2.6 & 0 & \\
\hline $\bar{x} 2=$ & 2.2 & 2.1 & 3.0 & 3.8 & 3.8 & 2.2 & 2.84 \\
\hline
\end{tabular}

Table 5b. 7-year-old plantations.

\begin{tabular}{|c|c|c|c|c|c|c|c|}
\hline \multirow{2}{*}{ CLONE } & \multicolumn{7}{|c|}{ SITE } \\
\hline & $\mathrm{ASH}$ & FAR & GRF & MIL & MON & SXF & $\overline{\mathrm{X}} 1$ \\
\hline DN-1 & $\begin{array}{c}---- \\
*\end{array}$ & $*$ & $\begin{array}{r}\text { tons } / \\
2.8\end{array}$ & $e / y_{*}$ & --- & $*$ & \\
\hline $\mathrm{DN}-17$ & 2.2 & 2.9 & 3.4 & 3.6 & 4.1 & 2.4 & 3.10 \\
\hline$N E-19$ & $*$ & 0 & * & * & $*$ & $*$ & \\
\hline$D N-34$ & 1.0 & 0 & 3.4 & 2.2 & 3.3 & 1.5 & 2.28 \\
\hline $\mathrm{NE}-41$ & * & * & * & 0 & $*$ & 0 & \\
\hline $\mathrm{NE}-47$ & * & * & * & * & 0 & * & \\
\hline$N E-54$ & 0 & 0 & 0 & 0 & 0 & 0 & \\
\hline $\mathrm{DN}-182$ & 1.3 & 2.8 & + & 3.2 & 4.1 & 2.1 & 2.70 \\
\hline $\mathrm{NE}-299$ & 2.3 & 0 & 0 & 0 & 0 & 0 & \\
\hline$N E-308$ & 2.1 & 0 & 2.5 & 3.0 & 2.6 & 2.7 & 2.58 \\
\hline$N E-387$ & 1.6 & 0 & + & 0 & 0 & 0 & \\
\hline SIOUX & 0.9 & 2.3 & 2.1 & 2.8 & 2.7 & 1.3 & 2.02 \\
\hline NC -5260 & 1.2 & 0 & 1.8 & 2.0 & 2.0 & 1.8 & \\
\hline$\overline{\mathrm{X}} 2$ & 1.5 & 2.7 & 2.8 & 3.0 & 3.4 & 2.0 & $\longdiv { 2 . 5 6 }$ \\
\hline
\end{tabular}

* Clone not planted.

0 Measurements terminated because of poor growth.

+ Clone removed for road construction. 


\section{Biomass production:}

Mean annual biomass production increased at most sites through 1994 (years 7 and 8) (Table 6). Only the Mondovi plantations are declining in production, and the oldest plantation at Ashland is static. The declines at Mondovi may be due to several possible causes including chemical damage (DN-34, 1988), Septoria musiva (DN-17 \& NE-308, 1987), and physiological maturity (DN-182, 1987). A few clonal blocks at most of the sites declined in biomass between 1993 and 1994 (Table 2). The frequency of decline was related to clonal disease resistance. DN-17, DN34, and DN182 which are some of the more resistant clones declined in only 1 or 2 blocks across the region (both plantation ages pooled). Whereas NE-308 and Siouxland clones which have a higher incidence of Septoria infection declined in 3 or 4 blocks.

Overall, biomass increased between 1993 and 1994 from 2.84 to 2.95 tons/acre/year (TAY) in the younger plantations, and from 2.56 to 2.68 TAY in the older plantations (Tables 2 and 5). For both ages the increase was between 4 and 5 percent. The original projections were that the plantations' mean annual biomass production would peak at age 10 for the $8 \times 8$ foot tree spacing. In view of the trends in Table 6, it appears that this is still a reasonable projection.

Recommendation: CONTINUE ANNUAL BIOMASS MEASUREMENTS UNTIL BIOMASS PRODUCTION HAS PEAKED AT MOST SITES.

The question of greatest interest is "what is the likely biomass yield in the region?" There are a number of clues to this question. Biomass production of the five best clones planted over all sites, currently averages nearly $3 \mathrm{TAY}$ (Table 2). The best clone (DN-34) over all sites averages 3.3 TAY, and the best site (Granite Falls) averages 3.9 TAY over all clones. The combination of the best clone $x$ site produces yields of 4.6-4.7 TAY. (The yield of 5.3 TAY for clone NE-19 at Granite Falls is discounted since the clone did so poorly everywhere else). So, with these five clones, one can expect yields of about 3 TAY with minimal site selection and 3.9 TAY with site selection. With site selection and using the current best clones, yields of 4.7 TAY are achievable. Keeping in mind that yields have not yet peaked in these plantations, these estimates are expected to increase somewhat in the next few years. Introduction of more disease resistant and faster growing clones will increase the yield potential over that reported here. Yields of some clones in the hybrid trials range up to 8.1 TAY illustrating the potential for greater yields with better clones. Also, reduction of early tree mortality (discussed in next section) would result in some increase in biomass.

This type of analysis does not address the issue of what percent of a large scale planting operation will actually be on high quality sites. Characterization and identification of good sites is poorly developed at this time. Some, (perhaps many) sites in a large planting program may be of poor quality. The effect of variable site quality (and consequently rigorous site selection) on average yields is illustrated by the data for 7-year-old plantations in Table 2 where the yield of 
the poorest and best site was 2.1 and 3.9 TAY respectively, and the average yield across all sites was right in the middle with 3.0 TAY.

Table 6. Mean Annual Biomass Production by site and year of planting. Data are the mean of the three best clones (DN17, DN34, and DN182).

\section{Site}

1987 plantings:

Ashland

Fargo

Granite Falls

Milaca

Mondovi

Sioux Falls

\begin{tabular}{|c|c|c|c|c|c|}
\hline \multicolumn{6}{|c|}{ Year } \\
\hline 1989 & 1990 & 1991 & 1992 & 1993 & 1994 \\
\hline
\end{tabular}

.15

.29

.79

.75

.55

.59
1.57

3.20

3.65

3.30

3.67 *

2.27
.97

1.85

1.63

1.55

1.82

2.10

2.53

1.10
1.27

1.75

1.90

2.53

3.23

1.73

1.67

1.25

1.93

1.93

$2.05 \quad 2.73$

1.23
1.93

1.75

2.27

2.33

3.50

1.60
1.50

2.85

3.40

3.00

3.83

2.00

2.13

1.85

3.13

4.07

4.00

2.27

Sioux Falls

* Biomass production is static or declining from 1993 to 1994. 


\section{Tree mortality:}

There was substantial tree mortality during the establishment year due to inadequate site preparation and weed control, the extensive nature of the plantation network, and to a lesser extent a historic record drought. Tree survival at the end of the first year averaged 73 percent. Since then, there has been little mortality of the better clones. (Some clones susceptible to disease had mortality of 100 percent at a young age.) Survival of the five best clones averaged 70 percent at the end of the first year across four sites (Table 7). Additional mortality through the eighth growing season was only 5 percent. Clone $\mathrm{NE}-308$ was unusual in that it had high initial survival but higher than average mortality in later years due to its susceptibility to septoria. Deleting the NE-308 data in Table 7 results in an average first year mortality for the remaining clones of 36 percent followed by only 2 percent additional mortality over the next seven years. With good site preparation and weed control, survival in individual clonal plots ranged up to 98 percent. The conclusion is that establishment year cultural practices are extremely important for initial survival, and that ensuing mortality in wellestablished and tended plantations is negligible.

Table 7. Tree survival at the end of year 1 and year 8 for selected sites and clones.

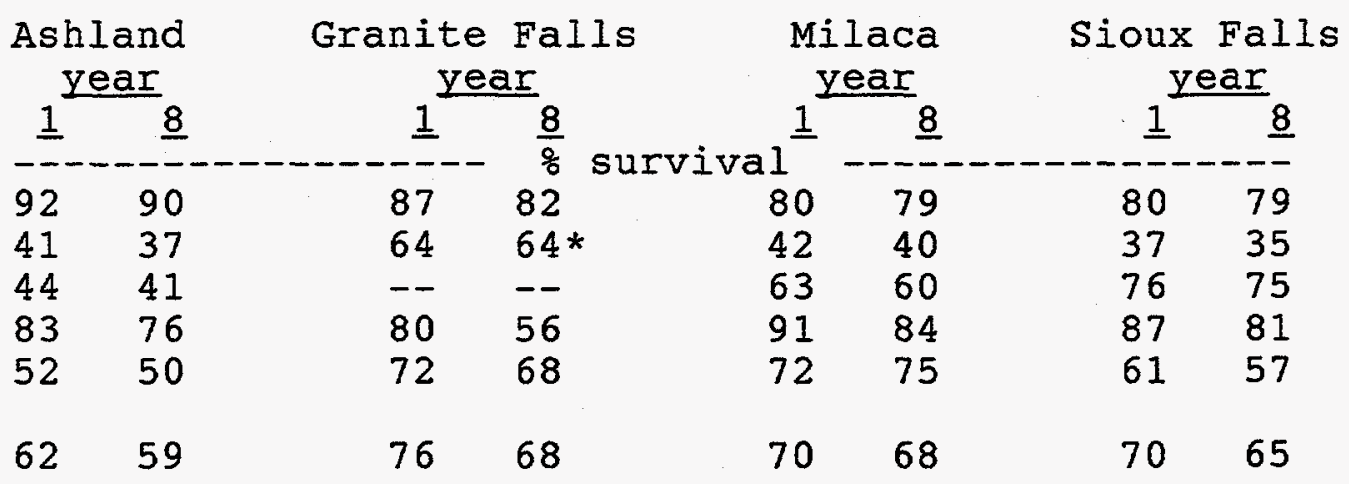

* Plot moved due to removal of original plot from road construction.

\section{Tree mortality and biomass production:}

A question that arises is "what would the biomass production be if survival had been 100 percent"? Data in Table 6 show that the 7-yearold (younger) plantations have greater biomass. At least part of this greater $y i e l d$ is due to greater survival (63 vs 58 percent for the 7and 8-year-old plantations respectively). Therefore, there is some basis to argue for adjusting yields based on survival. The major problem in making these estimates is that when trees die, the 
remaining living trees grow faster because they have additional growing space. This is called "compensatory growth". If the mean tree size of living trees is then used to calculate total biomass production assuming all trees had lived, the result is an over-estimate of the biomass. The size of this bias cannot be calculated with the data at hand. But the following illustrates that it exists: Biomass production in the measurement plots was significantly (positively) related to percent tree survival at many sites in 1991 and 1993, but at only one site in 1994 (Ashland--the slowest growing site, see Table 6 ). The declining frequency of significance over time suggests that trees in the lower-stocked plots (greater mortality) are growing faster and their biomass yields are catching up to the better-stocked plots. Recognizing that there is a bias to the procedure, the following calculations still provide a useful "upper-bounds" on biomass production estimates for the clones, site, and cultural tending under consideration. They do not necessarily represent achievable yields with 100 percent survival.

Projected biomass yields at 100 percent survival were calculated in two ways. First, the mean plot biomass for a site was adjusted by its difference in survival from 100 percent. Therefore, if the measured mean plot survival were 50 percent, the measured biomass would be doubled to give the resultant "adjusted mean site yield" at 100 percent as shown in Table 8. This gives an estimate of what the mean site yield might be for the mix of clones planted if survival were 100 percent. In the case of Ashland and Sioux Falls that already had high survival, this procedure produced little increase over the measured yields. On the other hand for Milaca and Mondovi where tree survival was lower, projected yields increased somewhat more. Since this procedure includes poor clones along with good clones, and includes areas of clumped mortality along with individual missing trees, it contains factors that tend to offset the bias originating from compensatory growth. It is our judgement that yields with 100 percent survival with this set of clones, sites, and cultural tending would probably fall somewhere between the "current" and "adjusted" values for the "mean site yield" in Table 8 .

A second procedure was to adjust the plot with the maximum biomass on each site by the difference of its measured survival from 100 percent survival. This procedure is judged to give estimates biased high because it is based on the record yield plot for each site which may not reflect the average potential for the entire site, and makes no allowance for compensatory growth. 
Table 8. Calculated site and plot biomass yields adjusted to a theoretical 100 percent survival (projected yields).

\begin{tabular}{|c|c|c|c|c|c|}
\hline \multirow{2}{*}{ Site } & \multirow{2}{*}{$\begin{array}{l}\text { mean site } \\
\text { survival* }\end{array}$} & mean $s$ & Ee yield & \multicolumn{2}{|c|}{ high plot yield } \\
\hline & & current & adjusted & current & adjusted \\
\hline & $--\frac{8}{8}---$ & $-\cdots-\cdots$ & - ton/ac & ear - - - & ------- \\
\hline Ashland & 82 & 2.2 & 2.6 & 2.7 & 2.7 \\
\hline Cloquet & 76 & 2.5 & 3.3 & 3.1 & 3.9 \\
\hline Fairmont & 78 & 3.0 & 3.8 & 3.5 & 4.3 \\
\hline Fargo & 73 & 2.9 & 4.0 & 3.2 & 4.3 \\
\hline Granite Falls & 76 & 4.1 & 5.4 & 5.3 & 6.6 \\
\hline Milaca & 68 & 3.1 & 4.5 & 3.9 & 4.9 \\
\hline Mondovi & 69 & 3.8 & 5.5 & 4.7 & 6.1 \\
\hline Sioux Falls & 89 & 2.4 & 2.7 & 3.0 & 3.0 \\
\hline
\end{tabular}

* Survival data does not generally correspond to data in Table 6 since Table 8 data are primarily from 7-year-old plantations.

Fertilization trials: (effect on leaf $N$ )

Operational fertilization of the regional plantation sites was based on guidelines from nutrient cycling/fertilization trials conducted earlier at Rhinelander applied in conjunction with systematic leaf sampling of the plantations during the mid-growing season. Based on previous research, it was believed that $\mathrm{N}$ is the nutrient most likely to be deficient and it was hypothesized that when leaf tissue $N$ concentration falls below $3 \%$, there would be a growth response to fertilization. No fertilization was required during the first six years with the exception of potassium at Cloquet during the first growing season and $N$ at Mondovi during the fifth growing season.

Annual monitoring of fertility status (with emphasis on $N$ ) began at all sites in 1990 when the plantations were in their third and fourth growing seasons. The objective was to determine when fertilization was needed, and to take appropriate action at that time. Leaf samples were collected from three clones (DN17, DN34, and DN182) at each site once during each growing season. In 1992 and 1993, leaf samples were collected in early July, randomly selected biomass measurement plots fertilized (different plots each year), leaf samples collected again from both fertilized and unfertilized plots 3 weeks later, and then at annual intervals. Tests were made for differences between the changes in nitrogen levels on the fertilized plots vs the changes in the unfertilized control plots for all sites pooled.

Fertilization in early July 1992 resulted in significant increases in leaf $N$ as measured in the post-fertilization sample 3-weeks later. Leaf $\mathrm{N}$ increased 20 percent from 2.73 to 3.20 percent. Samples one year later (in 1993) showed that leaf $N$ remained significantly elevated in the fertilized plots. However, two years after 
early July of 1993 showed the same pattern of significantly increased leaf $N$ the first year following treatment (in 1994) (Table 3 ).

Similar results were obtained in the designed fertilizer test at Milaca. In that test, the same treatments were repeated on a new set of plots for three years in a row (Table 9). Each year was treated as a replication in the analysis. Since leaf $\mathrm{N}$ in the control plots generally increased over the 3-week pre/post sampling period, an ANOVA was done on the DIFFERENCES between the two sampling periods (postpre) in leaf $\mathrm{N}$. Both the 75 and 150 lbs/acre of $N$ fertilization treatments over the three years showed a highly significant increase to $\mathrm{N}$ relative to the controls. Resampling the 1992 treatment plots in 1993 showed that leaf $N$ was still increased over the controls, and by the same magnitude as in the year of fertilization. The data show a slightly higher leaf $N$ with the 150 lbs/acre fertilization rate. But the difference over the 75 lbs/acre rate has no practical significance.

Table 9. Leaf nitrogen response in the year of fertilization at Milaca.

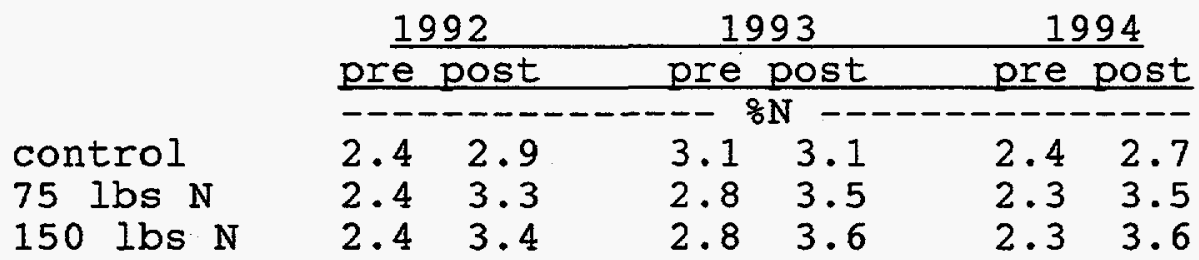

The results of the Milaca test corroborate the larger block plantings trials. They also agree with the previous single year analysis of Milaca results based on individual trees as the sample with no treatment randomization. These results show that fertilization at 75 or 150 lbs/acre $\mathrm{N}$ result in rapid increases in leaf $\mathrm{N}$ within 3 weeks which remain elevated for at least one year. One data set from the block plantings suggest that leaf $\mathrm{N}$ returns to the base level by the second year. Milaca measurements in 1994 were not made on the plots fertilized in 1992 and 1993, so this result on the duration of the fertilizer response could not be confirmed. Recommendation: MEASURE LEAF $N$ ON ALI PLOTS IN THE MILACA FERTILIZATION TEST IN 1995 AND ANALYZE FOR DURATION OF FERTILIZER RESPONSE. 
Fertilization trials: (effect on tree growth)

Measurements of the large block plantings showed no evidence of accelerated tree growth following fertilization in either 1992 or 1993. It is believed that one explanation for lack of any relation was the large variability in initial tree stocking. Poorly stocked tree plots grew faster than well stocked tree plots whether they were fertilized or not. Thus treatment was possibly obscured by variable tree stocking and hence variable growth rates.

There is some evidence from the Milaca test that fertilization may increase tree growth when measured in terms of annual dbh increment. The 1992 Milaca fertilizer treatment was followed by a 10 percent greater dbh increment in the fertilized plots (see replication 1 in Table 10). The 1993 treatment (replication 2) was followed by an even greater difference (29 percent) between the control and treated plots. However, the 1993 treatment data are suspect since the control plot has the smallest trees of any plot in the test and its growth had been progressively lagging behind the other plots even prior to treatment. Replication 3 was treated in 1994 and the results await collection of tree growth data in 1995. Analysis of the two replications (1993 replication 1, and 1994 replication 2) showed that the treatment effect is non-significant $(p=0.125)$. However it is quite possible that the addition of one more year of data (replication) will result in a significant effect of fertilization on tree growth.

Recommendation: MEASURE TREE DIAMETER ON ALL PLOTS IN THE MILACA FERTILIZER TEST IN 1995 AND ANALYZE FOR GROWTH RESPONSE TO FERTILIZATION. 
Table 10. Tree growth (DBH) response in Milaca fertilization test. Table 10a. DBH in $\mathrm{mm}$.

Replication

1

2

3

\begin{tabular}{llccr} 
Treatment & 1991 & 1992 & 1993 & 1994 \\
\hline control & 47.3 & 66.9 & 83.7 & 100.8 \\
75 lbs N & 45.3 & 66.7 & 85.0 & 101.4 \\
150 lbs N & 44.9 & 64.2 & 84.1 & 101.5 \\
& & & & \\
control & 42.7 & 60.5 & 75.5 & 88.3 \\
75 Ibs N & 44.8 & 64.8 & 81.5 & 99.0 \\
150 Ibs N & 42.9 & 63.7 & 79.8 & 97.7 \\
control & 43.1 & 66.4 & 82.8 & 99.3 \\
75 lbs N & 48.4 & 68.3 & 85.8 & 98.4 \\
150 lbs N & 46.0 & 64.2 & 80.0 & 95.6
\end{tabular}

Table 10b. DBH increment by year.

\begin{tabular}{|c|c|c|c|c|}
\hline Replication & Treatment & 1992 & 1993 & 1994 \\
\hline (2) & $\begin{array}{l}\text { control } \\
75 \text { lbs } N \\
150 \text { lbs N }\end{array}$ & $\begin{array}{l}------ \\
19.6 \\
21.4 \\
19.3\end{array}$ & $\begin{array}{c}\text { DBH (mm) } \\
\{16.8\} \\
\{18.3\} \\
\{19.9\}\end{array}$ & $\begin{array}{r}-17.1 \\
16.4 \\
17.4\end{array}$ \\
\hline 2 & $\begin{array}{l}\text { control } \\
75 \text { lbs } \mathrm{N} \\
150 \text { lbs } \mathrm{N}\end{array}$ & $\begin{array}{l}17.8 \\
20.0 \\
20.8\end{array}$ & $\begin{array}{l}15.0 \\
16.7 \\
16.1\end{array}$ & $\begin{array}{l}\{12 \cdot 8\} \\
\{17 \cdot 5\} \\
\{17 \cdot 9\}\end{array}$ \\
\hline 3 & $\begin{array}{l}\text { control } \\
75 \text { lbs } \mathrm{N} \\
150 \text { lbs } \mathrm{N}\end{array}$ & $\begin{array}{l}23.3 \\
19.9 \\
18.2\end{array}$ & $\begin{array}{l}16.4 \\
17.5 \\
15.8\end{array}$ & $\begin{array}{l}16.5 \\
12.6 \\
15.6\end{array}$ \\
\hline
\end{tabular}

$\{$ f first year growth following fertilization treatment 


\section{Clonal performance:}

Since 1986, 61 clonal trials have been established (41 remaining) with 40-80 clones in each trial (Hansen et. al, 1994). We tested more than 140 Populus selections in the program. An analysis of 91 clones planted in the 1987 and 1988 trials resulted in dropping 52 clones from the testing program because they did not exhibit reasonable growth or disease resistance on even half of the good sites. Plantations on drier (western) sites had fewer clones that met the selection criteria, and plantations on wetter (eastern) sites had more clones that met those criteria. Consequently test plantations were divided into "good" (eastern) and "harsh" (western) sites. More clones were judged reliable on good than on harsh sites, but the same clones that performed best on harsh sites were among those most reliable on good sites (Table :11). Nearly half of the 39 clones were 100 percent reliable on good sites. As site conditions (in this case primarily water availability) became less favorable, the number of reliable clones greatly decreased. Of the 39 clones, 25 clones on harsh sites did not meet the 50 percent reliability criterion in contrast to only 1 clone on good sites not meeting that criterion as determined by their frequency of being judged reliable on all planted sites.

The best survival and growth has been predominantly from clones of deltoides-nigra (DN) parentage. Other clones that are growing well are either nigra-maximowicsii, or pure deltoides parentage. Clones originating from the northeast U.S. (NE) are mostly severely diseased and some have died completely at some sites. The DN clones sold by regional commercial nurseries have been the best growers in our large block tests. These are DN-17, DN-34, and DN-182 (Robusta, Imperial Carolina or Eugenei, and Raverdeau respectively). However, there appear to be better clones under test in our hybrid trials. The best 36 clones from these trials were identified. These clones exhibit reasonable survival, good growth and moderate to high resistance to leaf rust and septoria canker. These 36 clones were provided to a state nursery for scale-up of planting stock production. We have since rouged out about half of these clones and released six clones to commercial nurseries in spring 1993 (DN2, DN5, DN70, NM6, NE222, I4551). These "newer" clones should be planted only on limited acreage until more experience is gained.

The results from the designed fertilizer test at Milaca permitted analyses of the 12 clones in the test. The results consistently showed highly significant differences between the clones in both leaf $\mathrm{N}$ and tree growth. The ranking of the clones in terms of growth corroborated the results of the larger hybrid trials across the region (see "1994 Clonal Performance"). Recommendation: CONTINUE ANNUAL GROWTH, SURVIVAL AND DISEASE ASSESSMENT OF THE HYBRID TRIALS UNTIL TRIALS WITH NEW GENETIC MATERIAL FROM ISU BREEDING PROGRAM HAVE MATERIAL AVAILABLE FOR COMMERCIAL RELEASE. 
Table 11-Ranking of 5- and 6-year-old clones* (planted 1987, 1988)

\begin{tabular}{|c|c|c|c|c|}
\hline \multirow[b]{2}{*}{ Clone } & \multicolumn{2}{|c|}{ Harsh sites } & \multicolumn{2}{|c|}{ Good sites } \\
\hline & Reliability & Sites & Reliability & Sites \\
\hline & Percent & Number & Percent & Number \\
\hline DN5 & 100 & 3 & 100 & 4 \\
\hline NM6 & 100 & 3 & 100 & 4 \\
\hline DN70 & 100 & 3 & 100 & 4 \\
\hline DN2 & 84 & 6 & 100 & 8 \\
\hline DN34 & 84 & 6 & 100 & 8 \\
\hline $145-51$ & 84 & 6 & 100 & 8 \\
\hline DN17 & 66 & 6 & 100 & 8 \\
\hline NE222 & 66 & 6 & 87.5 & 8 \\
\hline DN38 & 66 & 3 & 100 & 4 \\
\hline DN177 & 66 & 3 & 100 & 4 \\
\hline DN170 & 66 & 3 & 100 & 4 \\
\hline 1476 & 66 & 3 & 50 & 4 \\
\hline DN128 & 66 & 3 & 0 & 4 \\
\hline NE264 & 50 & 6 & 100 & 5 \\
\hline DN9 & 33 & 6 & 87.5 & 8 \\
\hline DN74 & 33 & 3 & 100 & 4 \\
\hline NM2 & 33 & 3 & 100 & 4 \\
\hline NC5377 & 33 & 3 & 100 & 4 \\
\hline DN16 & 33 & 6 & 75 & 8 \\
\hline $45-1$ & 33 & 6 & 75 & 8 \\
\hline DN174 & 33 & 3 & 75 & 4 \\
\hline DN131 & 33 & 6 & 62.5 & 8 \\
\hline DN173 & 33 & 3 & 50 & 4 \\
\hline DN179 & 33 & 3 & 50 & 4 \\
\hline DN55 & 16 & 6 & 100 & 8 \\
\hline DN182** & 16 & 6 & 100 & 8 \\
\hline DN1 & 0 & 3 & 100 & 4 \\
\hline SIOUX** & 16 & 6 & 87.5 & 8 \\
\hline DN181 & 0 & 3 & 75 & 4 \\
\hline NE35 & 16 & 6 & 62.5 & 8 \\
\hline NE295 & 0 & 6 & 62.5 & 8 \\
\hline DN18 & 16 & 6 & 50 & 8 \\
\hline DN106 & 0 & 3 & 50 & 4 \\
\hline NE49 & 0 & 6 & 50 & 8 \\
\hline DN114 & 0 & 6 & 50 & 8 \\
\hline NE300 & 0 & 3 & 50 & 4 \\
\hline NC5339 & 0 & 3 & 50 & 4 \\
\hline DTAC7 & 0 & 3 & 50 & 4 \\
\hline DTAC26 & 0 & 3 & 50 & 4 \\
\hline
\end{tabular}

"Clones with $>50$ percent reliability on at least one of two clusters of sites. where "reliability" = the percent of sites on which a given clone exhibited good growth relative to the other clones and fair resistance to Septoria through age 5 or 6 years.

**Clones in commerciai production at this time (inciudes all clones above line). 


\section{Soil water:}

Measurements of total water use (consumptive use) have shown that hybrid poplar plantations use 1-2 inches more moisture a month than what is supplied by average growing season precipitation in central wisconsin. A piezometer transect was established across the Milaca plantation. Measurements showed that the watertable (initially at the ground surface in May) declined beneath the plantation throughout the summer (Figure 4). The implication is that the trees were extracting much more water from groundwater than were the grass and shrub vegetation adjacent to the plantation. Since the Milaca plantation uses considerable groundwater in addition to rainfall input and is one of the fastest growing plantations in the network, it is concluded that water availability is a predominant factor in determining biomass production.

\section{Soil Carbon:}

This study investigated whether growing hybrid poplar plantations on tilled former grassland increases soil carbon (Hansen 1993). Existing hybrid poplar plantations were located across the region from eastern North Dakota into central Wisconsin. Nine sites were selected as suitable for the analysis. Comparisons were made in soil carbon levels between hybrid poplar plantations and adjacent row crops or mowed grass. It was concluded that hybrid poplar plantations grown on tilled agricultural lands previously in prairie, sequester significant quantities of soil carbon. Establishing and tending plantations often results in early soil carbon loss, but soil carbon is significantly related (positive) to tree age. Increasing tree age eventually results in a net addition of soil carbon from plantations older than about 6 to 12 years of age. Soil carbon loss under trees occurred most frequently from the surface $30 \mathrm{~cm}$ early in the plantation history--evidence that the loss was due to mineralization. Soil carbon gain was most significant in the $30-50 \mathrm{~cm}$ layer and was attributed to tree root growth. Soil carbon accretion rate beneath 12- to 18-year-old poplar plantations exceeded that of adjacent agricultural crops by $1.63+-0.16 \mathrm{Mg} \mathrm{ha}^{-1} \mathrm{yr}^{-1}$. There was a significant crop $x$ soil depth interaction for bulk density with bulk density lower beneath trees in the $0-30 \mathrm{~cm}$ layer and higher in the 30-50 cm layer. There was little evidence of carbon trapping of wind-blown organic detritus by tree plantations in the prairie environment. 
Figure 4. Watertable depression under the Milaca plantation.

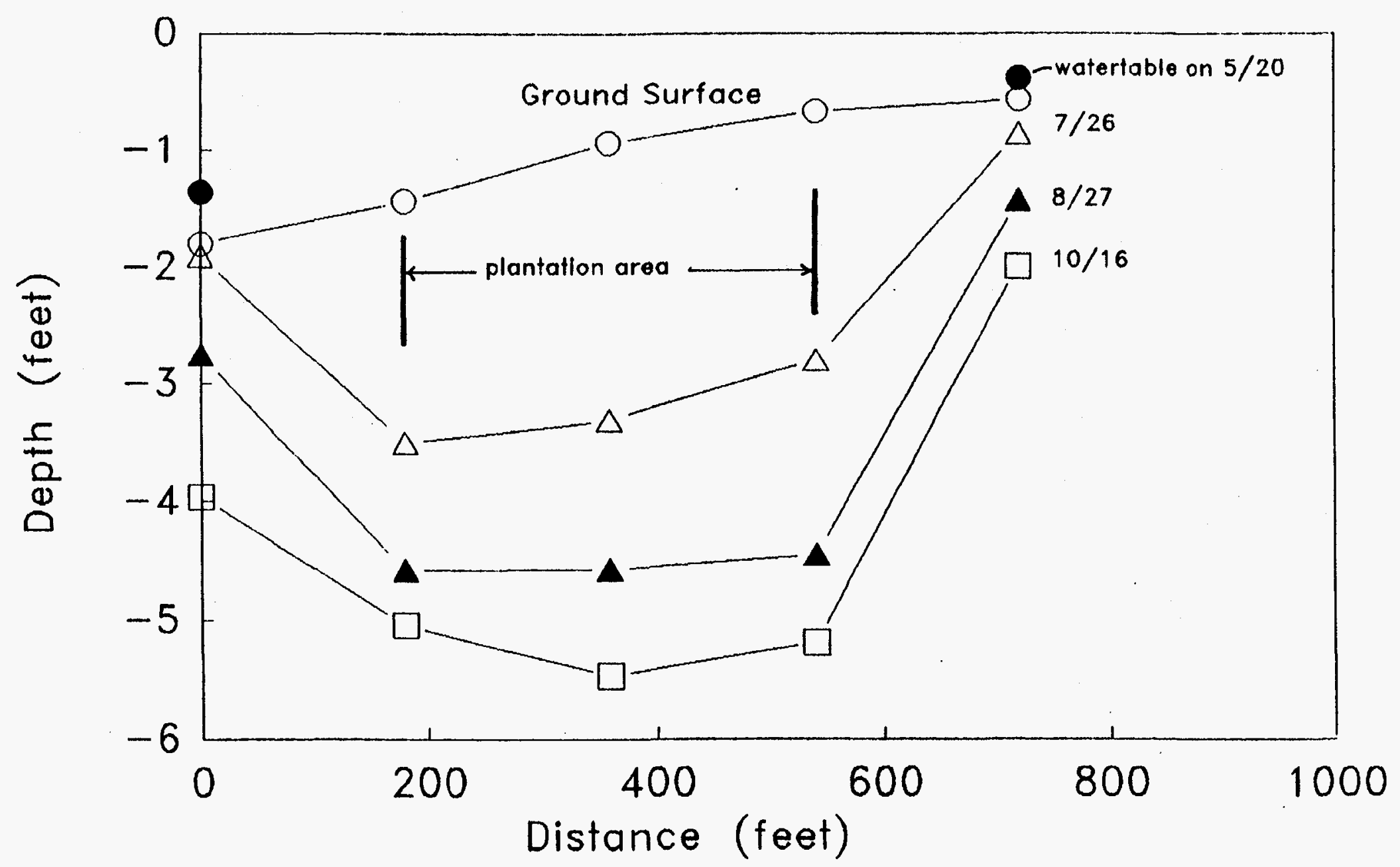




\section{Plantation Weed Control:}

Competition control is critical in establishing productive hybrid poplar plantations. Combinations of chemical and mechanical weed control strategies developed at the Harshaw Forestry Research Farm were implemented in the regional plantation network (Netzer and Hansen 1995). The preemergent herbicide linuron at one- to two-pounds active ingredient per acre is used during the first six weeks of plantation establishment. This chemical remains the only registered preemergent herbicide for hybrid poplar plantations. If linuron becomes ineffective before the trees are about 6-inches tall, a rotary hoe is operated over the trees to physically remove weeds. As the trees become taller than 6 inches small narrow discs of 5 and 6 foot in width are the most effective implement to control weeds. These discs are easy to transport and provided control of weeds in a variety of soil types. Small sprayers (less than 50 gallons) are mounted on top of these discs and used to apply grass herbicides such as sethoxydin at one-two pints per acre within the tree rows as the disc was operated between the rows.

Perennial grasses not controlled during the growing season are controlled by broadcast applications of glyphosate during late fall or spring when the hybrid poplars are dormant but the grasses are still active. This technique was developed through research conducted on four year old and younger plantations as well as coppice stool beds in 1990 (Netzer and Hansen 1992). Glyphosate at the rate of one pound active ingredient per acre was applied using commercial application techniques with no attempt to shield trees from the glyphosate spray mix. Chemical applications were made at two week intervals starting May 3 through september 11 with growth and damage recorded through the 1991 growing season. Significantly greater height growth occurred for the early May application date and significant height growth loss was noted for some clones following the June and July application dates (Figure 5). Application of glyphosate with the same rate and timing schedule, to coppice stool beds in July and August showed damage so severe to warrant this technique as a way to kill unwanted stoolbeds.

Sulfometuron (Oust) has also shown promise in dormant season applications in hybrid poplar plantations (Netzer 1995). This chemical has provided season-long weed control of most grasses and broadleaf weeds. Four trials were conducted in separate plantings in Wisconsin and Minnesota starting in 1987. A single application was made to each plantation without shielding the trees, similar to methods that might be used in commercial operations. Fall applications were made at rates from one- to three-ounces per acre ( 0.75 to 2.25 ounces active ingredient per acre) on October 23 when hybrid poplars were completely dormant. Spring applications at rates of one and two ounces per acre $(0.75$ and 1.5 ounces active ingredient per acre) were made April 18 and April 24. On the April 18 date the trees appeared completely dormant but on April 24 the trees had green leaf tips emerging from the buds. At each of the four sites height growth measurements, weed control, and tree damage observations were 
Figure 5 Hybrid poplar height growth related to date of glyphosate application during the third growing season (1990). Height growth is average of four DN clones and four NE clones.

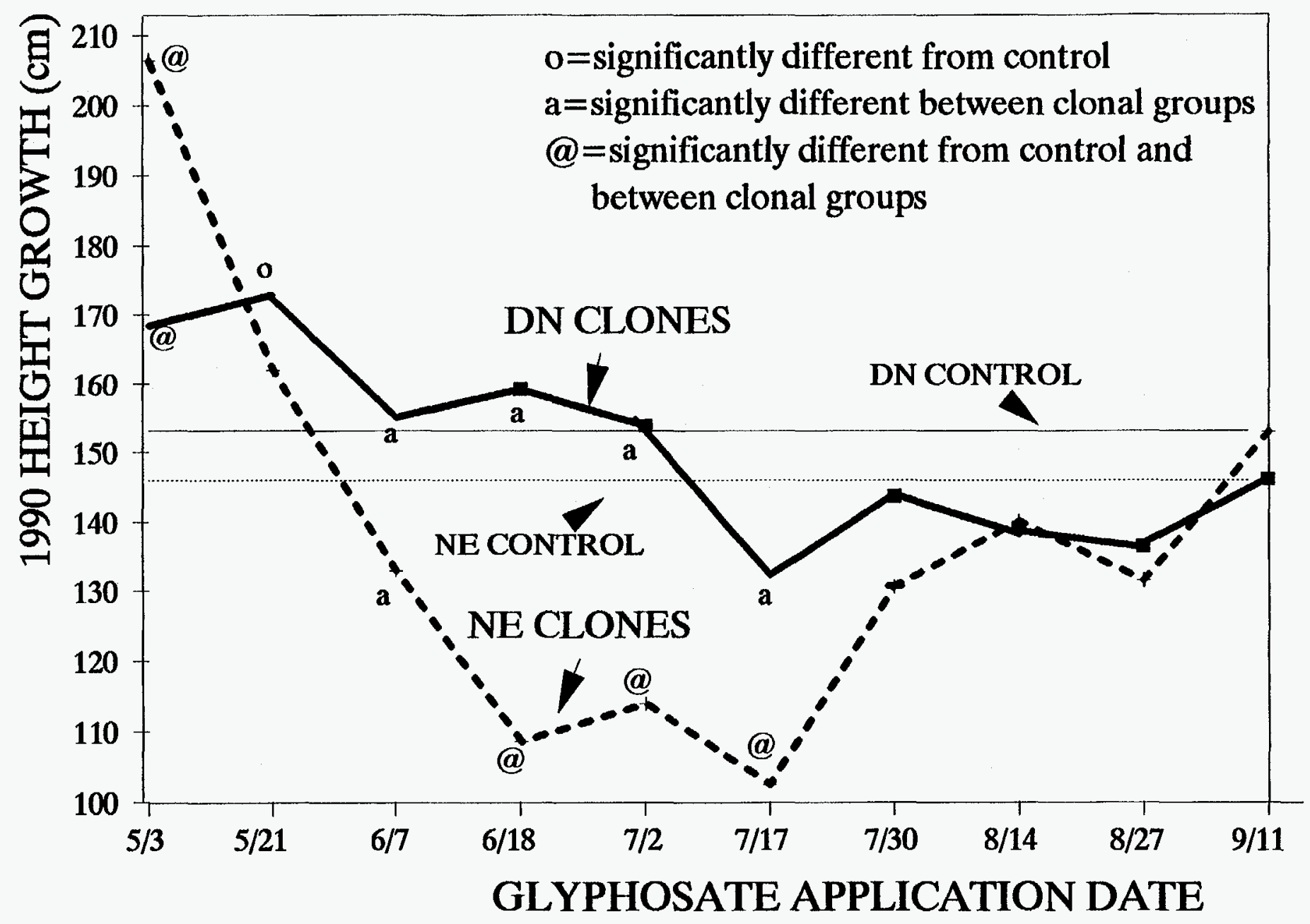


made at the end of the growing season following herbicide application. Herbicide rates and clones were replicated in some but not all trials. Spray dates were confounded by location. These trials suggested that low rates of sulfometuron, 70 grams per hectare ( 1 ounce product or 0.75 ounces active ingredient per acre), applied when hybrid poplar are completely dormant can provide season long control of weeds and result in increased hybrid poplar growth. Growth increases may be greater than from mechanical cultivation in drought years or dry areas. Damage to small trees and trees younger than one year may occur from broadcast applications if even slight growth activity is present. A few weeds may escape sulfometuron at low rates. Thistle seems most resistant to this herbicide and presents the greatest challenge to its use. Control of patches of thistle may be possible with directed spray of a contact herbicide like glyphosate. Late fall application of sulfometuron may be better than spring application if field access prior to spring weed growth is a concern.

\section{Genetic and Pathogenic Variability Within Septoria musiva.}

Host-parasite interactions are complex. Disease only develops if a pathogenic organism, a susceptible host, and a conducive environment are present. Screening poplars for resistance to disease requires a thorough understanding of these relationships and is further complicated by the age and size of trees, and expected rotation length. Septoria leaf spot, resulting in premature defoliation, and Septoria canker, resulting in stem breakage, are limiting diseases in many regions of North America. While our understanding of the biology of Septoria leaf spot and canker is fairly complete, our knowledge of the variability and genetics of the pathogen is extremely limited. In order to screen poplar clones for resistance we need to know the extent of pathogenic variability and distribution of pathotypes to reliably identify highly resistant trees and rank clones for their suitability as a biomass source when planted over a wide geographic region.

Collection of Septoria Isolates: A total of 859 Septoria musiva and Septoria populicola isolates have been collected. The collection consists of isolates recovered from 50 different hybrid poplar and aspen clones (diploid and triploid aspen), and native poplars (Populus alba, $\underline{P}$. balsamifera, $\underline{P}$. deltoides, $\underline{P}$. trichocarpa, and $\underline{\underline{P}}$. tremuloides). Isolates were collected from 21 locations in 8 states (MN, WI, SD, ND, IA, PA, OR, and WA) and in Canada.

Growth and Morphological Characteristics on Artificial Media: Various morphometric measurements were made on a selected group of 162 isolates. Isolates were highly variable in color, sporulation, morphology, and growth rate on various media. The overall mean diameter increase after 8 days was $7.8 \mathrm{~mm}$, ranging from 1.1 to 14.8 $\mathrm{mm}$. 
Leaf Disk Pathogenicity Assays: Leaf disks from poplars varying in susceptibility to Septoria were inoculated with 27 different isolates collected from 7 states (IA, MN, PA, OR, SD, WA, WI). On the average, green leaf tissue remaining 32 days after inoculation was $76 \%$ for the resistant clone and $46 \%$ for the susceptible clone. Isolates varied widely in pathogenicity, green leaf area remaining ranging from 0-94\% on the susceptible clone and from 34-97\% on the resistant clone. This is an indication that host specificity may need to be considered in this pathosystem before screening clones for resistance.

Host Differential Inoculations: Stem inoculations of poplar clones varying in susceptibility were done in the greenhouse using 10 isolates collected from 8 hybrid clones and native balsam poplar. After 14 days variation in canker development was expressed among the clones and isolates. Cankers ranged from 40-160 $\mathrm{mm}^{2}$, with some of the smaller cankers appearing to be inactive and walled-off by the host. Some isolates were more pathogenic on the susceptible clone than on the resistant clone, however, isolates recovered from clone $\mathrm{NE}$ 252 and I 45/51 were highly pathogenic on both. Other isolates, particularly one recovered from clone NE 242, was more pathogenic on the resistant clone than the susceptible clone. Recommendation:

ADDITIONAI RESEARCH IS NEEDED BEFORE ISOLATES CAN BE CHOSEN TO OBTAIN RELIABLE RESULTS IN RESISTANCE SCREENING TRIALS.

Molecular Marker Studies: Randomly amplified polymorphic DNA (RAPD) markers based on the polymerase chain reaction were used to detect genotypic differences among 235 isolates collected from various poplar hosts and geographic locations. Two Operon Primers have been used, F10 (5'GGAAGCTTGG3') and F-12 (5'ACGGTACCAG3'), and both have revealed a high number of fragments. DNA fragment size has ranged from 506$4,072 \mathrm{bp}$, and the number of fragments detected per isolate has ranged from 1-12. Fragment size among isolates is variable, however, there appears to be some "family" bands which are shared by groups of isolates. These are noticeable at $1,018,1,327$, and $2,036 \mathrm{bp}$, and may prove useful in distinguishing among septoria species.

Genetics Study: Work has been initiated on studying the heritability of markers in $\underline{S}$. musiva. Single ascospores are being isolated from individual asci in perithecia formed in infected leaves and RAPD analyses will be done to study dominance and recessiveness of various markers.

\section{Increase Resistance of a Selected Poplar clone to Infection by Septoria musiva.}

Tree improvement for such traits as disease resistance is a long-term, expensive activity. Tissue culture-generated variation and various rapid selection strategies have been used in many agronomic crops, and recently in forest trees to improve desired traits. Somaclonal selection for increased resistance to Septoria leaf spot has shown 
promise and may be a valuable strategy when used within the context of a classical breeding program for poplars.

We previously used tissue culture methods to increase the resistance of clone NE 299 (‥ nigra var betulifolia X P. trichocarpa). Based on the results of a laboratory bioassay, 15\% of the regenerated plants from callus cultures had increased resistance to $\underline{\text { s. musiva. Because }}$ of its rapid early growth and apparent tolerance to drought

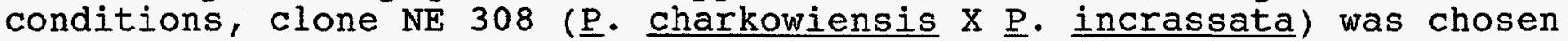
to further test somaclonal selection as a way to rapidly improve its resistance to septoria leaf spot and canker. $\mathrm{NE} 308$ is quite susceptible to septoria leaf spot and canker in the field and therefore cannot be recommended for planting at this time. If somaclonal variation in disease resistance can be utilized in this clone as it was in $\mathrm{NE} 299$, then the somaclonal selection strategy would be worth pursuing further with additional clones.

The tissue culture and plant regeneration systems needed to handle this genotype were optimized. Clone NE 308 proved to be much more difficult to propagate in vitro than many of the other poplar clones tested. Plantlet regeneration, rooting, and acclimation of $\mathrm{NE} 308$ were difficult as well, supporting our previous results indicating extreme variability in success of tissue culture within populus clones and species.

During the course of this study over 900 adventitious shoots from callus were generated from NE 308. Of these, over 500 plants (somaclones) survived rooting and acclimation to greenhouse conditions. Many mutant plants died soon after being moved to greenhouse conditions, and others died from various other causes. addition, 356 plants regenerated from axillary buds, and plants regenerated from hardwood and softwood cuttings of $\mathrm{NE} 308$ were established in the greenhouse. Plants regenerated from axillary buds and cuttings served as control plants in the bioassays and will be outplanted with selected somaclones for field testing. In previous work it was found that axillary bud culture could induce somatic variation in populus, indicating that the tissue culture cycle itself may result in instability of some clones when grown in vitro.

All NE 308 somaclones have been tested at least twice for resistance to septoria leaf spot using the leaf disk laboratory bioassay. Thus far, with only a few plants needing re-testing, out of 486 somaclones we have recovered 29 plants that have tested resistant twice. The resistant somaclones averaged over $20 \%$ greater green leaf area 32 days after inoculation. In addition, disease progression on leaf disks of several somaclones was delayed compared to the donor clone which may serve to delay sporulation and thus limit disease spread. Most regenerated plants, however, tested as susceptible as the donor (non tissue-cultured) plant. We have propagated several of these which also will be included in our field test for comparison of their disease reactions and growth characteristics to the resistant somaclones and the donor clone. 
To be considered true somaclonal variants, genetic analyses must be done. At Rhinelander, WI we have NE 299 somaclones that have exhibited resistance to Septoria canker since they were planted in 1986. All plants of $\mathrm{NE} 299$ in this planting that did not undergo a tissue culture cycle have been killed by septoria canker. These trees are being maintained in the test plot and will be allowed to flower. Although breeding work has not been done with somaclones with putative resistance to Septoria leaf spot and canker, tests are underway to determine if the disease resistance trait is stable after vegetative propagation. Plants vegetatively propagated using conventional cuttage techniques have been under test at Rosemount, MN. Also, we have over 200 "generation 2" NE 308 plants. These are plants propagated using softwood cuttings of selected somaclone lines. Field testing of this plant population will begin in the summer in a replicated planting at Rosemount, MN.

Somaclones of NE 299 have been field-tested under natural inoculum levels and cultural conditions. Trees have been assessed for growth, form, and most importantly, resistance to all major insects and pathogens in addition to $\underline{\mathrm{S}}$. musiva. Somaclones of $\mathrm{NE} 308$ will undergo similar testing. Selected trees will then be propagated and will be made available to collaborators for further testing and potential breeding.

\section{Related Research Supporting Short Rotation Woody Crop Trials}

Poplar Clonal Trials: Disease Screening: Poplar selections in the clonal trials established in the region have been monitored for resistance to the major limiting diseases. This work has resulted in the identification of a group of clones that have exhibited good growth and a high level of resistance or tolerance to disease over a range of sites. Of importance is the detection of some site differences in relation to disease incidence and disease severity. Available soil moisture may play a critical role in disease expression and impact. The common set of clones across a wide range of sites also allows monitoring of the pathogen populations affecting trees. Collections of various fungi are being made from selected clones in several of the trials for identification and comparison purposes.

Bird and Small Mammal Use of Hybrid Poplar Plantations: A separately funded study is investigating the effect of replacing traditional agricultural row, grain and hay crops with perennial tree plantations. The question is one of determining the relative value of tree crops for food, cover and nesting for a variety of birds and mamals as compared to the nominal agricultural landscape.

Biological Control of Septoria Leaf spot and Canker: Laboratory assays using the bacterium streptomyces scabies demonstrated antibiotic activity against many of the $s$. musiva isolates collected during the course of our research. Variation in antibiotic activity among $\underline{S}$. scabies isolates was evident as was variability in the level of 
inhibition of isolates of $\underline{S}$. musiva by a given $\underline{S}$. scabies isolate. $\underline{S}$. scabies is found in soil and on infected plant debris, and may be an effective control agent on many sites where poplars are being grown. Reduction of over-wintering inoculum on infected leaves will most likely reduce disease incidence and severity the following spring. It may especially be effective as a preventative treatment in nursery stool beds and on planting stock.

Detection and Identification of Poplar Leaf Rusts: In conjunction with the International Energy Agency Bioenergy Agreement Task Working Groups on Pest/Disease Control and Exchange, a common set of poplar clones have been planted in Wisconsin, Minnesota, Iowa, and washington with the objective of detecting and monitoring the leaf rust populations present over this geographic range. We now know that several species and races of Melampsora are present in the poplargrowing regions of North America and that serious disease outbreaks caused by newly-evolved or introduced pathotypes can occur. The goal is to gain knowledge of the distribution of the various rust populations so that effective rust resistance screening can be undertaken. 


\section{CONCLUSIONS}

1. Mean annual biomass production for the five best clones over the eight test sites averages 3 dry tons per acre per year (TAY).

2. The best clone (DN-34) averages 3.3 TAY over all sites.

3. The best site (Granite Falls) averages 3.9 TAY over all clones.

4. The best clone at the best site yields 4.6-4.7 TAY.

5. Other clones in the small clonal trial plots have yields up to 8.1 TAY.

6. Biomass yields are still increasing at most sites through year 8 .

7. Biomass yields would probably be somewhat higher if the high mortality during the establishment year had been avoided.

8. Establishment year mortality was 27 percent. Subsequent mortality of the best four clones was only 2 percent through year 8 .

9. Reduced growth at some sites was related primarily to insufficient soil water and susceptibility to the disease Septoria musiva.

10. Fertilization at 75 and 150 pounds per acre $N$ resulted in significant increases in leaf tissue $N$.

11. Leaf $\mathrm{N}$ remained elevated through the first growing season following fertilization, but early results indicate that effects probably do not carry over to the second year.

12. No significant increase in tree growth following fertilization has been detected.

13. Clones with the best survival and growth are predominantly of deltoides-nigra parentage; other clones that are growing well are either nigra-maximowicsii, or pure deltoides parentage.

14. The same clones are the best growers on both "good" and "harsh" sites.

15. Most clones from the northeast U.S. (NE) are severely diseased and some have died completely at some sites.

16. A collection of 859 Septoria spp. isolates has shown considerable variability in the microorganism.

17. Inoculation tests indicate that host specificity may need to be considered when screening clones for resistance. 
18. Hybrid poplar plantations grown on tilled agricultural lands previously in prairie, sequester significant quantities of soil carbon.

19. Establishment and tending of the plantation can lead to early soil carbon loss, but this is replaced as the plantation ages.

20. Glyphosate can be applied safely to poplar plantations during the tree dormancy periods in early spring and late fall.

21. Sulfometuron has shown promise for season-long weed control from a single application during the tree dormancy periods in early spring and late fall.

22. About half of the total cost for tending the plantations through year $8(\$ 470-\$ 660)$ was required for the first year establishment and tending cost.

\section{RECOMMENDATIONS}

1. Continue annual biomass measurements until biomass production has peaked at most sites.

2. Measure leaf $\mathrm{N}$ on all plot in the Milaca fertilization test in 1995 and analyze for duration of fertilizer response.

3. Measure tree diameter on all plots in the Milaca fertilizer test in 1995 and analyze for growth response to $\mathrm{N}$ fertilization.

4. Continue annual growth, survival and disease assessment of the hybrid trials until trials with new genetic material from ISU breeding program have material available for commercial release.

5. Additional research is needed before isolates can be chosen to obtain reliable results in resistance screening trials. 


\section{PUBLICATIONS}

Hall, R. B., M. E. Ostry, and N. E. Nordh. 1992. IEA joint trials:new lessons from old plantations. Biomass and Bioenergy 2: 85-94.

Hansen, Edward. 1990. Early yields of biomass plantations in the north-central U.S. USDA Forest Service, North Central Forest Experiment Station, St. Paul MN. Research Note NC-353. 6 pp.

Hansen, Edward, David Tolsted, and Matthew Tower. 1991. Planting depth of hybrid poplar cuttings influences number of shoots. U.S. Department of Agriculture, Forest Service, North Central Forest Experiment Station, St. Paul MN. Research Note NC-355. 4 pp.

Hansen, Edward. 1991. Energy plantations in north central United States: status of research and development plantations. Energy Sources $13(1): 105-110$.

Hansen, Edward. 1991. Poplar woody biomass yields: A look to the future. Biomass and Energy 1(1): 1-7.

Hansen, Edward. 1991. Concepts for wood energy pilot. In: Proceedings, Biomass feedstock/conversion scale-up activities and issues working group meeting. 1991 June 19; Washington DC. Washington DC: U.S. Department of Energy: Section II-1.

Hansen, Edward. 1992. Short rotation woody crop trials for energy production in north central U.S. Proceedings of the annual automotive technology development contractors' coordination meeting; 1991 October 28-31; Dearborn MI. Warrendale PA: American Society of Automotive Engineers, Inc. Publ. No. P-256: 715-716.

Hansen, Edward A. 1992. Biological opportunities to increase tree biomass accumulation and yield from timberland. In: Qureshi, Ata, editor. Proceedings, Forests in a changing climate - North American Conference on forestry responses to climate change; 1990 May 15-17; Washington DC. Climate Institute. pp. 104-114.

Hansen, Edward A. 1992. Mid-rotation yields of biomass plantations in the north central United States. U.S. Department of Agriculture, Forest Service, North Central Forest Expierment station, St. Paul MN. Research Paper NC-309. 8 pp.

Hansen, Edward, Paul Heilman, and Silvia Strobl. 1992. Clonal testing and selection for field plantations. In: Mitchell, C. P.; J. B. FordRobertson; T. Hinckley; and I. Sennerby-Forsse. Ecophysiology of Short Rotation Forest Crops. Essex, England: Elsevier Science Publishers, Ltd. pp. 124-145.

Hansen, Edward A., Daniel A. Netzer, and David N. Tolsted. 1993. Guidelines for establishing poplar plantations in the north-central U.S. USDA Forest Service, North Central Forest Experiment Station, St. 
Paul MN. Research Note NC-363. $6 \mathrm{pp}$.

Hansen, Edward A. 1994. Soil carbon sequestration beneath hybrid poplar plantations in the north central United States. Biomass and Bioenergy 5(6): 431-436.

Hansen, Edward A. 1994. A guide for determining when to fertilize hybrid poplar plantations. U.S. Department of Agriculture, Forest Service, North Central Forest Experiment Station, St. Paul, MN. Research Paper NC-319, 7 pp.

Hansen, Edward, Mike Ostry, Wendell Johnson, Dave Tolsted, Dan Netzer, Bill Berguson, Richard Hall. 1994. Field performance of populus in short rotation intensive culture plantations in north central U.S. U.S. Department of Agriculture, Forest Service, North Central Forest Experiment Station, St. Paul, MN. Research Paper NC-320, 13 pp.

Moltzan, B. D., R. W. Stack, P. A. Mason, and M. E. Ostry. 1993. First report of Melampsora occidentalis on Populus trichocarpa in the central United States. Platn Disease 77: 953.

Netzer, Daniel A. 1995. Use of Sulfometuron in hybrid poplar energy plantations. USDA Forest Service, North Central Forest Experiment Station, St. Paul MN. Research Note RN-NC-366. $6 \mathrm{pp}$.

Netzer, Daniel and Edward Hansen. 1992. Seasonal variation in hybrid poplar tolerance to glyphosate. USDA Forest Service, North Central Forest Experiment Station, St. Paul MN. Research Paper NC-311. 7 pp.

Netzer, Daniel A., and Edward A. Hansen. 1994. Establishment and tending of poplar plantations in north-central U.S. In: Mechanization in short rotation, intensive culture forestry. March 1-3, 1994, Mobile, AI. p. 79-87.

Ostry, M. E. Somatic variation in disease resistance of poplars. Proceedings, International Energy Agency Joint Meeting of the Task $V$ Activity Groups on Exchange of Genetic Material, Pest/Disease Management, and Joint trials of Alnus, Populus, and Salix. Ames IA.

Ostry, M.E. 1994. Poplar disease research: host resistance and pathogen variability. Norwegian Journal of Agricultural Sciences Supplement No. 18: 89-94.

Ostry, M. E. and H. S. MCNabb, Jr. 1990. Minimizing disease injury to hybrid poplars. J. Environ. Hort. 8: 96-98.

Ostry, M. E., D. D. Skilling, O. Y. Lee-Stadelmann, and W. P. Hackett. 1990. Recovery of somatic variation in resistance of Populus to Septoria musiva. In: Rodriquez, R., et al., (eds). Plant Aging: Basic and Applied Approaches. New York: Plenum Press. pp. 113-116. 
Ostry, M. E., B. Bucciarelli, S. Sain, W. P. Hackett, and N. A. Anderson. 1990. Developing tissue culture systems for increasing the disease resistance of aspen. In: Adams, R. D., ed. Aspen Symposium '90. Gen. Tech. Rep. NC-140: 315-318.

Ostry, M. E. and K. T. Ward. 1991. Bibliography of Populus cell and tissue culture. U.S. Department of Agriculture, Forest Service, North Central Forest Experiment Station, st. Paul MN. Gen. Tech. Rep. $\mathrm{NC}-146.26 \mathrm{p}$.

Ostry, M. E. and N. A. Anderson. 1992. Biological control of Septoria musiva using suppressive strains of streptomyces scabies. In: Proceedings of the joint meeting of the International Energy Agency Meeting; 1992 September 14-18; Enniskillen, Northern Ireland.

Ostry, M. E. and C. H. Michler. 1992. Use of biotechnology for tree improvement in Populus model systems. In: Ahuja, M. R., editor. Micropropagation of woody plants. Kluwer Academy Pub. pp. 471-483.

Ostry, M. E. and W. E. Berguson. 1993. Selecting hybrid poplars to reduce disease risk may also reduce biomass yield. Tree Planters' Notes.

Ostry, M. E., M. W. Hackett, C.Michler, R. Serres, and B. McCown. 1994. Influence of regeneration method and tissue source on the frequency of somatic variation in Populus to infection by septoria musiva. Plant Science 97: 209-215.

Rhodenbaugh, Eric. 1991. Water stress effects on photosynthesis and root growth in three Populus clones. U. of Missouri. MS Thesis. 140 pp.

Royle, D.J. and M.E. Ostry. 1995. Disease and pest control in the bioenergy crops: poplar and willow. Biomass and Bioenergy (in press).

Shimizu, K. 1994. Biological control of septoria leaf spot on hybrid poplars using Streptomyces spp. MS Thesis, University of Minnesota, St. Paul, MN, $48 \mathrm{p}$.

Strong, Terry. 1989. Rotation length and repeated harvesting influence of Populus coppice production. USDA Forest Service, North Central Forest Experiment Station, St. Paul MN. Research Note NC-350. 4 pp.

Strong, Terry and Edward A. Hansen. 1991. Response of three Populus species to drought. U.S. Department of Agriculture, Forest Service, North Central Forest Experiment Station, st. Paul MN. Research Paper $\mathrm{NC}-302.9 \mathrm{pp}$.

Strong, Terry and Edward Hansen. 1992. Hybrid poplar spacing/productivity relations in short rotation intensive culture plantations. Biomass and Bioenergy 4(4): 255-261. 
Tolsted, David and Edward Hansen. 1992. Age of hybrid poplar stools at first cut influences third-year cutting production. U.S. Department of Agriculture, Forest Service, North Central Forest Experiment Station, St. Paul MN. Research Note NC-357. 3 pp.

Ward, K. T., M. E. Ostry, and G. R. Furnier. 1992. Genetic and pathogenic variability of Septoria musiva. In: Columbo, S. J.; G. Hogan; and V. Wearn, editors. Proceedings, 12th North American Forest Biology Workshop; 1992 August 17-20; Sault Ste. Marie, Ontario. p. 62 (abstract).

Ward, K. T. and M. E. Ostry. 1993. Mid-rotation disease impact on hybrid poplar plantations in the north-central United States. American Journal of Botany 80: 83 (abstract).

Ward, K.T., M.E. Ostry, and G.R. Furnier. 1994. Morphological and molecular genetic variation among isolates of Septoria musiva. (Abstr.) Phytopathology 84:1145. 
LOCATION: ASHLAND, WI - 1987 (1-YEAR-OLD PLANTATION)

\begin{tabular}{|c|c|c|c|c|c|c|c|c|c|c|c|c|}
\hline OPERATION & ACBES & $\begin{array}{l}\text { TREATED } \\
\text { ACRES }\end{array}$ & $\begin{array}{c}\text { MAJOR } \\
\text { ACTIVITY } \\
\text { CATEGORY } \\
\end{array}$ & SUBACTIVITY & $\begin{array}{l}\text { SPECIFIC } \\
\text { ACTIVITY }\end{array}$ & DATE & YEAR & MACHINERY USED & PROVIDER & $\begin{array}{l}\text { UNIT } \\
\text { COST }\end{array}$ & $\begin{array}{l}\text { TOTAL } \\
\text { COST }\end{array}$ & $\begin{array}{c}\text { COST } \\
\text { PER } \\
\text { PROJECT } \\
\text { ACRE }\end{array}$ \\
\hline A & 10 & 10 & $\begin{array}{c}\text { Site } \\
\text { Preparation }\end{array}$ & Mechanical & Moldboard plowing & $11 / 86$ & 0 & $\begin{array}{l}60 \mathrm{HP} \text { tractor w/3 } \\
\text { bottom moldboard } \\
\text { plow }\end{array}$ & $\begin{array}{l}\text { Farmer } \\
\text { (contract) }\end{array}$ & $\$ 30 / \mathrm{hr}$ & $\$ 135.00$ & $\$ 13.50$ \\
\hline B & 10 & 10 & $\begin{array}{c}\text { Stte } \\
\text { Preparation }\end{array}$ & Mechanical & Dlscing & 4/87 & 1 & $\begin{array}{l}60 \mathrm{HP} \text { tractor with } \\
10 \text { foot wide disc }\end{array}$ & $\begin{array}{l}\text { Farmer } \\
\text { (contract) }\end{array}$ & $\$ 30 / \mathrm{hr}$ & $\$ 105.00$ & $\$ 10.50$ \\
\hline c & 10 & 10 & $\begin{array}{c}\text { Site } \\
\text { Preparation }\end{array}$ & Chemical & $\begin{array}{l}\text { Linuron tretment } \\
\text { Linuron chemical } \\
2 \text { lbs/acre }\end{array}$ & 4/87 & 1 & $\begin{array}{l}26 \text { HP tractor with } \\
30 \text { foot boom } \\
\text { sprayer }\end{array}$ & $\begin{array}{l}\text { Farmer } \\
\text { (contract) } \\
\text { coop }\end{array}$ & $\begin{array}{l}\$ 10 / a c r e \\
\$ 6.10 / 1 \mathrm{~b}\end{array}$ & $\begin{array}{l}\$ 100.00 \\
\$ 122.00\end{array}$ & $\begin{array}{l}\$ 10.00 \\
\$ 12.20\end{array}$ \\
\hline D & 10 & 10 & $\begin{array}{l}\text { Planting } \\
\text { Cuttings }\end{array}$ & Planting & Hand planting & $4 / 87$ & 1 & $\begin{array}{l}\text { Hand planting at } \\
8^{\prime} \times 8^{\prime}\end{array}$ & $\begin{array}{l}\text { Contract } \\
\text { crew } \\
5.5 \text { hours } \\
5 \text { persons }\end{array}$ & $\begin{array}{l}\$ 0.0975 / \\
\text { cutting } \\
\$ 0.09 / \\
\text { cutting }\end{array}$ & $\begin{array}{l}\$ 656.37 \\
\$ 605.88\end{array}$ & $\begin{array}{l}\$ 66.60 \\
\$ 61.20\end{array}$ \\
\hline E & 10 & 10 & Tending & Mechanical & $\begin{array}{l}\text { Culltivation in two } \\
\text { directions }\end{array}$ & $7 / 87$ & 1 & $\begin{array}{l}26 \mathrm{HP} \text { tractor } W / 7 \\
\text { disc }\end{array}$ & $\begin{array}{l}\text { NCFES } \\
9.5 \mathrm{hrs}\end{array}$ & $\$ 18.00$ & $\$ 171.00$ & $\$ 17.10$ \\
\hline $\mathrm{F}$ & 10 & 10 & Tending & Mechanical & $\begin{array}{l}\text { Cultivation in two } \\
\text { directions }\end{array}$ & $8 / 87$ & 1 & $\begin{array}{l}26 \mathrm{HP} \text { tractor W/7' } \\
\text { disc }\end{array}$ & NCFES & $\$ 18.00$ & $\$ 180.00$ & $\$ 18.00$ \\
\hline$G$ & 10 & 10 & Tending & Chemical & $\begin{array}{l}\text { Linuron/glyphosate } \\
\text { Linuron chemical } \\
\text { Glyphosate } \\
\text { chemical }\end{array}$ & $11 / 87$ & 1 & $\begin{array}{l}26 \mathrm{HP} \text { tractor w/42' } \\
\text { boom } \\
2 \text { pints/acre } \\
3 \text { pints/acre }\end{array}$ & NCFES & $\begin{array}{l}\$ 20.00 / \mathrm{hr} \\
\$ 74.00 / \mathrm{ga} \\
\$ 59.54 / \mathrm{ga}\end{array}$ & $\begin{array}{l}\$ 80.00 \\
\$ 185.00 \\
\$ 219.71\end{array}$ & $\begin{array}{l}\$ 8.00 \\
\$ 18.50 \\
\$ 21.97\end{array}$ \\
\hline
\end{tabular}


LOCATION: SIOUX FALLS, SD - 1987 (1-YEAR-OLD PLANTATION)

\begin{tabular}{|c|c|c|c|c|c|c|c|c|c|c|c|c|}
\hline OPERATION & ACRES & $\begin{array}{l}\text { TREATED } \\
\text { ACRES }\end{array}$ & $\begin{array}{c}\text { MAJOR } \\
\text { ACTIVITY } \\
\text { CATEGORY }\end{array}$ & SUUBACTIVITY & $\begin{array}{l}\text { SPECIFIC } \\
\text { ACTIVITY }\end{array}$ & DATE & YEAR & MACHINERY USED & PROVIDER & $\begin{array}{l}\text { UNIT } \\
\text { COST }\end{array}$ & $\begin{array}{l}\text { TOTAL } \\
\text { COST }\end{array}$ & $\begin{array}{c}\text { COST } \\
\text { PER } \\
\text { PROJECT } \\
\text { ACRE }\end{array}$ \\
\hline A & 10 & 10 & $\begin{array}{c}\text { Site } \\
\text { preparation }\end{array}$ & Mechanical & $\begin{array}{l}\text { Chisel plow followed } \\
\text { by } 2 \text { passes with } \\
\text { field cultivator }\end{array}$ & $4 / 87$ & 1 & $\begin{array}{l}75 \text { HP tractor w/10' } \\
\text { chisel plow }\end{array}$ & $\begin{array}{l}\text { Farmer } \\
\text { (contract) }\end{array}$ & & $\$ 100.00$ & $\$ 10.00$ \\
\hline B & 10 & 10 & $\begin{array}{c}\text { Site } \\
\text { Preparation }\end{array}$ & $\begin{array}{l}\text { Chemical } \\
\text { Linuron }\end{array}$ & $\begin{array}{l}\text { Linuron treatment } \\
\text { Linuron chemical }\end{array}$ & $4 / 87$ & 1 & $\begin{array}{l}75 \text { HP tractor w/30' } \\
\text { boom sprayer } \\
\text { Linuron chemical }\end{array}$ & $\begin{array}{l}\text { Farmer } \\
\text { (contract) } \\
\text { Coop }\end{array}$ & & $\begin{array}{l}\$ 40.00 \\
\$ 275.00\end{array}$ & $\begin{array}{l}\$ 4.00 \\
\$ 27.50\end{array}$ \\
\hline C & 10 & 10 & $\begin{array}{l}\text { Planting } \\
\text { Cuttings }\end{array}$ & Planting & Hand planting & $4 / 87$ & 1 & $\begin{array}{l}\text { Hand planting at } \\
8 \text { 'x } 8^{2} \\
680 \text { trees/acre } \\
\text { Cuttings }\end{array}$ & $\begin{array}{l}\text { Contract } \\
\text { crew (5) }\end{array}$ & $\begin{array}{l}9.75 \\
\text { cents/ } \\
\text { cutting } \\
9 \text { cents } \\
\text { ea }\end{array}$ & $\begin{array}{l}\$ 663.00 \\
\$ 612.00\end{array}$ & $\begin{array}{l}\$ 66.30 \\
\$ 61.20\end{array}$ \\
\hline$D$ & 10 & 10 & Tending & Chemical & $\begin{array}{l}\text { Fluazifop treatment } \\
\text { Fluazifop chemical }\end{array}$ & $6 / 87$ & 1 & $\begin{array}{l}75 \mathrm{HP} \text { tractor } w / 30^{\prime} \\
\text { boom sprayer } \\
\text { Fluazifop chemical }\end{array}$ & $\begin{array}{l}\text { Farmer } \\
\text { (contract) } \\
\text { Coop }\end{array}$ & & $\begin{array}{l}\$ 40.00 \\
\$ 174.00\end{array}$ & $\begin{array}{l}\$ 4.00 \\
\$ 17.40\end{array}$ \\
\hline $\mathbf{E}$ & 10 & 10 & Tending & Chemical & $\begin{array}{l}\text { Glyphosate spot } \\
\text { spray }\end{array}$ & $6 / 87$ & 1 & 1 person @ $\$ 4.50 / \mathrm{hr}$ & $\begin{array}{l}\text { Farmer } \\
\text { (contract) } \\
\text { Coop }\end{array}$ & & $\$ 101.25$ & $\$ 10.13$ \\
\hline & & & & & $\begin{array}{l}\text { Glyphosate } \\
\text { chemical }\end{array}$ & & & $\begin{array}{l}\text { Glyphosate } \\
\text { chemical }\end{array}$ & & & $\$ 62.50$ & $\$ 6.25$ \\
\hline $\mathbf{F}$ & 10 & 10 & Tending & Mechanical & $\begin{array}{l}\text { Mowing between } \\
\text { tree rows }\end{array}$ & $7 / 87$ & 1 & $\begin{array}{l}18 \mathrm{HP} \text { tractor w/5 } \\
\text { toot wide rotary } \\
\text { mower }\end{array}$ & $\begin{array}{l}\text { Farmer } \\
\text { (contract) }\end{array}$ & & $\$ 50.00$ & $\$ 10.00$ \\
\hline G & 10 & 10 & Tending & Mechanical & $\begin{array}{l}\text { Mowing between } \\
\text { tree rows }\end{array}$ & $8 / 87$ & 1 & $\begin{array}{l}18 \mathrm{HP} \text { tractor } w / 5 \\
\text { foot wide rotary } \\
\text { mower }\end{array}$ & $\begin{array}{l}\text { Farmer } \\
\text { (contract) }\end{array}$ & & $\$ 20.00$ & $\begin{array}{c}\$ 4.00 \\
5\end{array}$ \\
\hline$H$ & 10 & 10 & Tending & Hand Weeding & Hand weeding & $7,8 / 87$ & 1 & $\begin{array}{l}4 \text { persons @ } \\
\$ 5.00 / \mathrm{hr} \text {. }\end{array}$ & Farmer & & $\$ 577.50$ & $\$ 57.50$ \\
\hline 1 & 10 & 10 & Tending & Chemical & $\begin{array}{l}\text { Cottonwood leal } \\
\text { beatle control }\end{array}$ & $8 / 87$ & 1 & $\begin{array}{l}\text { Backpack mist } \\
\text { blower } \\
\text { Malathion chemical }\end{array}$ & NCFES & & $\begin{array}{l}\$ 17.00 \\
\$ 10.16\end{array}$ & $\begin{array}{l}\$ 1.70 \\
\$ 1.02\end{array}$ \\
\hline $\mathrm{J}$ & 10 & 10 & Tending & Chemical & Linuron treatment & $11 / 87$ & 1 & $\begin{array}{l}26 \mathrm{HP} \text { tractor } w / 42 \\
\text { boom }\end{array}$ & NCFES & & $\$ 70.00$ & $\$ 7.00$ \\
\hline & & & & & Linuron chemical & & & 2 pints/acre & & $\$ 74.00 / \mathrm{ga}$ & $\$ 185.00$ & $\$ 18.50$ \\
\hline
\end{tabular}




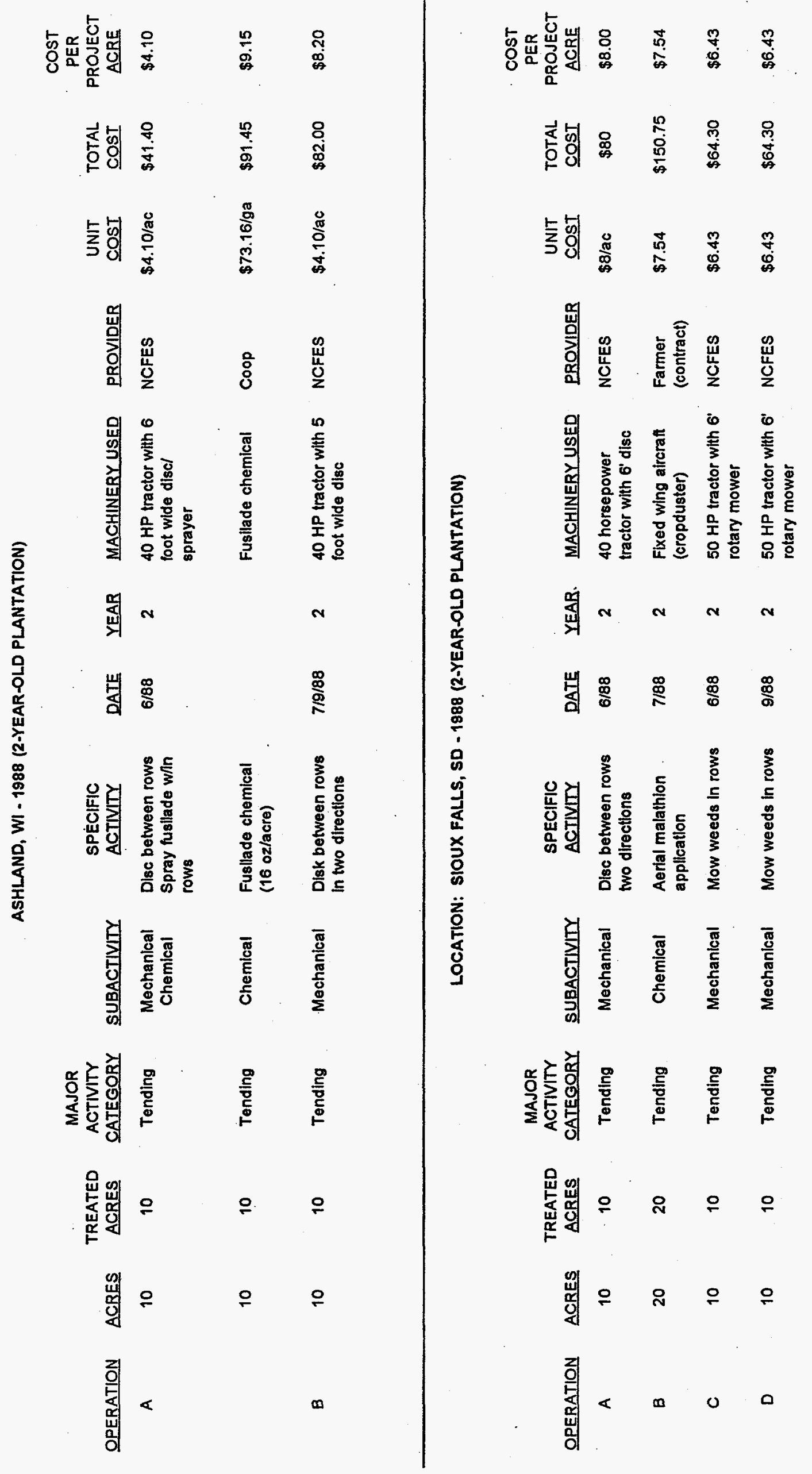


LOCATION: ASHLAND, WI - 1989 (3-YEAR-OLD PLANTATION)

\begin{tabular}{|c|c|c|c|c|c|c|c|c|c|c|c|c|}
\hline OPERATION & ACRES & $\begin{array}{l}\text { TREATED } \\
\text { ACRES }\end{array}$ & $\begin{array}{c}\text { MAJOR } \\
\text { ACTIVITY } \\
\text { CATEGORY }\end{array}$ & SUBACTIVITY & $\begin{array}{l}\text { SPECIFIC } \\
\text { ACTIVITY }\end{array}$ & DATE & YEAR & MACHINERY USED & PROVIDER & $\begin{array}{l}\text { UNIT } \\
\text { COST }\end{array}$ & $\begin{array}{l}\text { TOTAL } \\
\text { COST }\end{array}$ & $\begin{array}{c}\text { COST } \\
\text { PER } \\
\text { PROJECT } \\
\text { ACRE }\end{array}$ \\
\hline A & 10 & 10 & Tending & Chemlcal & $\begin{array}{l}\text { Spring glyphosate } \\
\text { overspray }\end{array}$ & $5 / 89$ & 3 & $\begin{array}{l}50 \mathrm{HP} \text { tractor with } \\
42 \text { spray boom }\end{array}$ & NCFES & $\$ 4.00 / a c$ & $\$ 40.00$ & $\$ 4.00$ \\
\hline B & 10 & 10 & Tending & Chemical & Roundup chemlcal & $5 / 89$ & 3 & $1 \mathrm{lb} / \mathrm{acre}$ (1 qt/acre) & $\begin{array}{l}\text { Chemical } \\
\text { company }\end{array}$ & $\$ 54.59 / \mathrm{ga}$ & $\$ 136.48$ & $\$ 13.48$ \\
\hline c & 10 & 10 & Tending & Mechanical & $\begin{array}{l}\text { Disk between rows } \\
\text { in one direction }\end{array}$ & $6 / 89$ & 3 & $\begin{array}{l}50 \text { HP tractor with 6" } \\
\text { disk }\end{array}$ & NCFES & $\$ 4.10 / a c$ & $\$ 41.00$ & $\$ 4.10$ \\
\hline D & 10 & 10 & Tending & $\begin{array}{l}\text { Mechanical } \\
\text { Chemical }\end{array}$ & $\begin{array}{l}\text { Dlsk between rows } \\
\text { Spray Fusllade } \\
\text { within rows }\end{array}$ & $7 / 89$ & 3 & $\begin{array}{l}50 \mathrm{HP} \text { tractor with } 6^{\prime} \\
\text { disk and attached } \\
\text { sprayer }\end{array}$ & NCFES & $\$ 4.10 / a c$ & $\$ 41.00$ & $\$ 4.10$ \\
\hline E & 10 & 10 & Tending & Chemical & Fusllade chemical & $7 / 89$ & 3 & & $\begin{array}{l}\text { Chemical } \\
\text { company }\end{array}$ & $\$ 73.16 / g a$ & $\$ 91.45$ & $\$ 9.15$ \\
\hline $\mathbf{F}$ & 10 & 10 & Tending & Mechanical & $\begin{array}{l}\text { Mow between rows } \\
\text { in one direction }\end{array}$ & $8 / 89$ & 3 & $\begin{array}{l}50 \mathrm{HP} \text { tractor with } 6 \\
\text { rotary mower }\end{array}$ & NCFES & $\$ 6.43 / a c$ & $\$ 64.30$ & $\$ 6.43$ \\
\hline G & 10 & 20 & Tending & Mechanlcal & $\begin{array}{l}\text { Disk between rows } \\
\text { In } 2 \text { directions }\end{array}$ & $8 / 89$ & 3 & $\begin{array}{l}5 Q \text { HP tractor with 6' } \\
\text { disk }\end{array}$ & NCFEES & $\$ 4.10 / a c$ & $\$ 41.00$ & $\$ 4.10$ \\
\hline
\end{tabular}


LOCATION: SIOUX FALLS, SD - 1989 (3-YEAR-OLD PLANTATION)

\begin{tabular}{|c|c|c|c|c|c|c|c|c|c|c|c|c|}
\hline OPERATION & ACRES & $\begin{array}{l}\text { TREATED } \\
\text { ACRES }\end{array}$ & $\begin{array}{c}\text { MAJOR } \\
\text { ACTIVITY } \\
\text { CATEGORY } \\
\end{array}$ & SUBACTIVITY & $\begin{array}{l}\text { SPECIFIC } \\
\text { ACTIVITY }\end{array}$ & DATE & YEAR & MACHINERY USED & PROVIDER & $\begin{array}{l}\text { UNIT } \\
\text { COST }\end{array}$ & $\begin{array}{l}\text { TOTAL } \\
\text { COST }\end{array}$ & $\begin{array}{c}\text { COST } \\
\text { PER } \\
\text { PROJECT } \\
\text { ACRE }\end{array}$ \\
\hline A & 10 & 10 & Tending & Mechanical & $\begin{array}{l}\text { Disk between rows } \\
\text { in one direction }\end{array}$ & $6 / 89$ & 3 & $\begin{array}{l}50 \mathrm{HP} \text { tractor with } 5^{\prime} \\
\text { disk }\end{array}$ & NCFES & $\$ 4.10 / 2 c$ & $\$ 41.00$ & $\$ 4.10$ \\
\hline B & 10 & 10 & Tending & Mechanical & $\begin{array}{l}\text { Mow between rows } \\
\text { In ane direction }\end{array}$ & $7 / 89$ & 3 & $\begin{array}{l}50 \text { HP tractor with } 6^{\prime} \\
\text { rotary mower }\end{array}$ & NCFES & $\$ 6.43 / \mathrm{ac}$ & $\$ 64.30$ & $\$ 6.43$ \\
\hline D & 10 & 10 & Tending & Chemical & $\begin{array}{l}\text { Apply granular } \\
\text { simazine }\end{array}$ & $11 / 89$ & 3 & $\begin{array}{l}50 \text { HP tractor with } \\
\text { attached cyclone } \\
\text { type spreader }\end{array}$ & NCFES & $\$ 5.00 / a c$ & $\$ 50.00$ & $\$ 5.00$ \\
\hline$E$ & 10 & 10 & Tending & Chemical & Simazine chemical & $11 / 89$ & 3 & $\begin{array}{l}\text { Simazine applied at } \\
100 \mathrm{lbs} / \mathrm{acre}\end{array}$ & $\begin{array}{l}\text { Chemical } \\
\text { company }\end{array}$ & $\$ 1.21 / \mathrm{b}$ & $\$ 1210.00$ & $\$ 121.00$ \\
\hline
\end{tabular}


LOCATION: ASHLAND, WI - 1990 (4-YEAR-OLD PLANTATION)

\begin{tabular}{|c|c|c|c|c|c|c|c|c|c|c|c|c|}
\hline OPERATION & ACRES & $\begin{array}{l}\text { TREATED } \\
\text { ACRES }\end{array}$ & $\begin{array}{c}\text { MAJOR } \\
\text { ACTIVITY } \\
\text { CATEGORY } \\
\end{array}$ & SUBACTIVITY & $\begin{array}{l}\text { SPECIFIC } \\
\text { ACTIVITY }\end{array}$ & DATE & YEAR & MACHINERY USED & PROVIDER & $\begin{array}{l}\text { UNIT } \\
\text { COST }\end{array}$ & $\begin{array}{l}\text { TOTAL } \\
\text { COST }\end{array}$ & $\begin{array}{c}\text { COST } \\
\text { PER } \\
\text { PROJECT } \\
\text { ACRE }\end{array}$ \\
\hline A & 10 & 10 & Tending & Chemical & $\begin{array}{l}\text { Granular herbicide } \\
\text { appllcation }\end{array}$ & $4 / 90$ & 4 & $\begin{array}{l}\text { 4-wheeler with } \\
\text { attached cyclone- } \\
\text { type spreader }\end{array}$ & NCFES & $\$ 5.48 / a c$ & $\$ 54.80$ & $\$ 5.48$ \\
\hline B & 10 & 10 & Tending & Chemlcal & Simazine granular & $4 / 90$ & 4 & $\begin{array}{l}3 \mathrm{lb} / a c r e \text { active } \\
\text { Ingredients } \\
75 \text { lbs/acre bag mix }\end{array}$ & $\begin{array}{l}\text { Chemical } \\
\text { Company }\end{array}$ & $\$ 1.40 / \mathrm{lb}$ & $\$ 1050.00$ & $\$ 105.00$ \\
\hline
\end{tabular}

LOCATION: SIOUX FALLS, SD - 1990 (4-YEAR-OLD PLANTATION)

\begin{tabular}{|c|c|c|c|c|c|c|c|c|c|c|c|c|}
\hline OPERATION & ACRES & $\begin{array}{l}\text { TREATED } \\
\text { ACRES }\end{array}$ & $\begin{array}{c}\text { MAJOR } \\
\text { ACTIVITY } \\
\text { CATEGORY } \\
\end{array}$ & SUBACTIVITY & $\begin{array}{l}\text { SPECIFIC } \\
\text { ACTIVITY }\end{array}$ & DATE & YEAR & MACHINERY USED & PROVIDER & $\begin{array}{l}\text { UNIT } \\
\text { COST }\end{array}$ & $\begin{array}{l}\text { TOTAL } \\
\text { COST }\end{array}$ & $\begin{array}{c}\text { COST } \\
\text { PER } \\
\text { PROJECT } \\
\text { ACRE }\end{array}$ \\
\hline A & 9 & 9 & Tending & Chemical & $\begin{array}{l}\text { Directed glyphosate } \\
\text { spray }\end{array}$ & $6 / 90$ & 4 & $\begin{array}{l}\text { 4-wheeler with } 6 \\
\text { foot wide boom } \\
\text { trailer sprayer }\end{array}$ & NCFES & $\$ 5.48 / a c$ & $\$ 49.32$ & $\$ 5.48$ \\
\hline B & 9 & 9 & Tending & Chemical & $\begin{array}{l}\text { Glyphosate } \\
\text { (Roundup) }\end{array}$ & $6 / 90$ & 4 & & $\begin{array}{l}\text { Chemical } \\
\text { company }\end{array}$ & $\$ 54.59 / \mathrm{ga}$ & $\$ 122.83$ & $\$ 13.64$ \\
\hline c & 9 & 4 & Tending & Mechanical & $\begin{array}{l}\text { Cut thistles with } \\
\text { hand-held weed } \\
\text { mower }\end{array}$ & $6 / 90$ & 4 & $\begin{array}{l}\text { Motorized hand-held } \\
\text { weed culter }\end{array}$ & NCFES & $\$ 15.00 / a c$ & $\$ 60.00$ & $\$ 15.00$ \\
\hline
\end{tabular}


LOCATION: ASMLAND, WISCONSIN - 1991 (5-YEAR-OLD PLANTATION)

TOTAL TREATED ACTIVITY

OPERAIION ACRES ACRES CATECORY

$\wedge \quad 10 \quad i \quad$ Tending and around planting
DATE XR MACLINERY USED

28 IIP tractor with $6 \mathrm{ft}$. rotary mower
PROVIDER

NCFES
COST PER

UNIT COST TOTAL COST PROJECT ACRE

$\$ 15.00 / a c \quad \$ 150.00$

LOCATION: SIOUX FALLS, SOUTU DAKOTA - 1991 (5-YEAR-OLD PLANTATION)

TOTAL TREATED ACTIVITY

OPERATION ACRES ACRES CATEGORY

\begin{tabular}{|c|c|c|c|c|c|}
\hline$\wedge$ & 9 & 9 & Tending & Chemlcal & $\begin{array}{l}\text { Spring glyphoso } \\
\text { application }\end{array}$ \\
\hline B & 9 & 9 & Tend Ing & Chemical & Glyphosate \\
\hline c & 10 & 10 & Tending & Chemleal & $\begin{array}{l}\text { Cottonwood leat } \\
\text { beotlo }\end{array}$ \\
\hline D & 10 & 10 & Tend1ng & Chemlcal & Malatbion ULV \\
\hline E & 9 & 9 & Tending & Mechanlcal & $\begin{array}{l}\text { Mow thistle } \\
\text { betwoon rows }\end{array}$ \\
\hline$\eta$ & 3 & 9 & Tendlng & Mechanlcal & $\begin{array}{l}\text { Disk In two } \\
\text { dircetlons }\end{array}$ \\
\hline
\end{tabular}

Y DATE YR MACAINERY USED

$5 / 915$ 4-wheeler whth boom sprayer

\section{$5 / 9151 \mathrm{~L} / \mathrm{b} / \mathrm{ac}$}

(1 $\mathrm{qt} / \mathrm{ac})$

6/915 Plxed-wing alrcraft

$6 / 915 . \quad 1$ qt/acre

$7 / 91528$ HP tractor with 6 ft rotary mower

$9 / 91528$ IP tractor with $6 \mathrm{ft}$-wide disk
PROVIDER UNIT COST COST PER

NCFES

$\$ 5.48$

$\$ 49.32$

$\$ 5.18$

Chemlcal

Company

$\$ 54.59 / 8 a \quad \$ 122.83$

\$ 13.64

Contract

$\$ 10.00 /$ ac. $\$ 100.00$

$\$ 10.00$

Chemlcal

$\$ 26.45 / \mathrm{ga} \quad \$ 66.13$

$\$ 15.00 /$ ac $\$ 135.00$

$\$ \quad 6.61$

NCFES

NCFES

$\$ 15.00 / a c \quad \$ 270.00$

$\$ \quad 15.00$

$\$ 30.00$ 
LOCATION: ASHLAND, WI - 1992 (6-YEAR-OLD PLANTATION)

\begin{tabular}{|c|c|c|c|c|c|c|c|c|c|c|c|c|}
\hline OPERATION & ACRES & $\begin{array}{l}\text { TREATED } \\
\text { ACRES }\end{array}$ & $\begin{array}{c}\text { MAJOR } \\
\text { ACTIVITY } \\
\text { CATEGORY } \\
\end{array}$ & SUBACTIVITY & $\begin{array}{l}\text { SPECIFIC } \\
\text { ACTIVITYY }\end{array}$ & DATE & YEAR & MACHINERY USED & PROVIDER & $\begin{array}{l}\text { UNIT } \\
\text { COST }\end{array}$ & $\begin{array}{l}\text { TOTAL } \\
\text { COST }\end{array}$ & $\begin{array}{c}\text { COST } \\
\text { PER } \\
\text { PROJECT } \\
\text { ACRE }\end{array}$ \\
\hline A & 10 & 5 & Tending & Chemical & $\begin{array}{l}\text { Spring glyphosate } \\
\text { application }\end{array}$ & $5 / 92$ & 6 & $\begin{array}{l}28 \mathrm{HP} \text { tractor } 6 \text { foot } \\
\text { wide boom sprayer }\end{array}$ & NCFES & $\$ 5.48 / a c$ & $\$ 27.40$ & $\$ 5.48$ \\
\hline B & 10 & 5 & Tending & Chemical & Roundup chemical & $5 / 92$ & 6 & $1 \mathrm{lb} / \mathrm{acre}$ (1 qt/acre) & $\begin{array}{l}\text { Chemical } \\
\text { Company }\end{array}$ & $\$ 54.59 / \mathrm{ga}$ & $\$ 68.23$ & $\$ 13.64$ \\
\hline
\end{tabular}

LOCATION: SIOUX FALLS, SD - 1992 (6-YEAR-OLD PLANTATION)

\begin{tabular}{|c|c|c|c|c|c|c|c|c|c|c|c|c|}
\hline OPERATION & ACRES & $\begin{array}{c}\text { TREATED } \\
\text { ACRES }\end{array}$ & $\begin{array}{c}\text { MAJOR } \\
\text { ACTIVITY } \\
\text { CATEGORY }\end{array}$ & SUBACTIVITY & $\begin{array}{l}\text { SPECIFIC } \\
\text { ACTIVITY }\end{array}$ & DATE & YEAR & MACHINERY USED & PROVIDER & $\begin{array}{l}\text { UNIT } \\
\text { COST }\end{array}$ & $\begin{array}{l}\text { TOTAL } \\
\text { COST }\end{array}$ & $\begin{array}{c}\text { COST } \\
\text { PER } \\
\text { PROJECT } \\
\text { ACRE }\end{array}$ \\
\hline A & 9 & 9 & Tending & Chemical & $\begin{array}{l}\text { Spring glyphosate } \\
\text { application }\end{array}$ & $5 / 92$ & 6 & $\begin{array}{l}28 \mathrm{HP} \text { tractor with } 6 \\
\text { foot boom sprayer }\end{array}$ & NCFES & $\$ 5.48$ & $\$ 49.32$ & $\$ 5.48$ \\
\hline B & 9 & 9 & Tending & Chemical & Roundup chemlcal & $5 / 92$ & 6 & $1 \mathrm{lb} / \mathrm{acre}$ (1 qt/acre) & $\begin{array}{l}\text { Chemical } \\
\text { Company }\end{array}$ & $\$ 54.59 / \mathrm{ga}$ & $\$ 122.83$ & $\$ 13.64$ \\
\hline c & 9 & 9 & Tending & Mechanical & Mow weeds in rows & $7 / 92$ & 6 & $\begin{array}{l}28 \mathrm{HP} \text { tractor with } 6 \\
\text { foot wide rotary } \\
\text { mower }\end{array}$ & NCFES & $\$ 15.00 / a c$ & $\$ 135.00$ & $\$ 15.00$ \\
\hline D & 9 & 9 & Tending & Mechanical & $\begin{array}{l}\text { Disc between rows } \\
\text { two directlons }\end{array}$ & $8 / 92$ & 6 & $\begin{array}{l}28 \text { HP ractor with } 6 \\
\text { foot tandem disc }\end{array}$ & Contractor & $\$ 20 / \mathrm{hr}$ & $\$ 140.00$ & $\$ 15.50$ \\
\hline
\end{tabular}


LOCATION: ASHLAND, WI - 1993 (7-YEAR-OLD PLANTATION)

There were no tending activities on the plantation in 1993. A strrip around the outside edge of the planting was mowed once and the cost is noted below:

\begin{tabular}{|c|c|c|c|c|c|c|c|c|c|c|c|c|}
\hline OPERATION & ACRES & $\begin{array}{l}\text { TREATED } \\
\text { ACRES }\end{array}$ & $\begin{array}{c}\text { MAJOR } \\
\text { ACTIVITY } \\
\text { CATEGORY }\end{array}$ & SUBACTIVITY & $\begin{array}{l}\text { SPECIFIC } \\
\text { ACTIVITY }\end{array}$ & DATE & YEAR & MACHINERY USED & PROVIDER & $\begin{array}{l}\text { UNIT } \\
\text { COST }\end{array}$ & $\begin{array}{l}\text { TOTAL } \\
\text { COST }\end{array}$ & $\begin{array}{c}\text { COST PER } \\
\text { PROJECT } \\
\text { ACRE }\end{array}$ \\
\hline A & 10 & 0.6 & Tending & Mechanical & $\begin{array}{l}\text { Mow outside edge } \\
\text { of plantation }\end{array}$ & $7 / 93$ & 7 & $\begin{array}{l}28 \text { HP tractor } 6 \text { foot } \\
\text { wide rotary mower }\end{array}$ & NCFES & $\$ 15.00 / a c$ & $\$ 9.00$ & $\$ 15.00$ \\
\hline
\end{tabular}

LOCATION: SIOUX FALLS, SD - 1993 (7-YEAR-OLD PLANTATION)

\begin{tabular}{|c|c|c|c|c|c|c|c|c|c|c|c|c|}
\hline OPERATION & ACRES & $\begin{array}{c}\text { TREATED } \\
\text { ACRES }\end{array}$ & $\begin{array}{c}\text { MAJOR } \\
\text { ACTIVITY } \\
\text { CATEGORY }\end{array}$ & SUBACTIVITY & $\begin{array}{l}\text { SPECIFIC } \\
\text { ACTIVITY }\end{array}$ & DATE & YEAR & MACHINERY USED & PROVIDER & $\begin{array}{l}\text { UNIT } \\
\text { COST }\end{array}$ & $\begin{array}{l}\text { TOTAL } \\
\text { COST }\end{array}$ & $\begin{array}{c}\text { COST } \\
\text { PER } \\
\text { PROJECT } \\
\text { ACRE }\end{array}$ \\
\hline A & 9 & 9 & Tending & Mechanical & $\begin{array}{l}\text { Mow thistle between } \\
\text { tree rows }\end{array}$ & $8 / 93$ & 7 & $\begin{array}{l}28 \mathrm{HP} \text { tractor } 6 \text { foot } \\
\text { wide rotary mower }\end{array}$ & NCFES & $\$ 15.00 / a c$ & $\$ 135.00$ & $\$ 15.00$ \\
\hline
\end{tabular}

LOCATION: ASHLAND, WI - 1994 (8-YEAR-OLD PLANTATION)

There were no tending activitles on the plantation in 1994.

LOCATION: SIOUX FALLS, SD - 1994 (8-YEAR-OLD PLANTATION)

There were no tending activities on the plantation in 1994. 
TREE DRY WEIGHT DATA

(8X8 feet spacing)

ASHLAND (1987 plantation)

\begin{tabular}{|c|c|c|c|c|c|c|}
\hline CLONE & $\frac{\mathrm{DBH}}{\mathrm{cm}}$ & $\frac{\mathrm{HGT}}{\mathrm{m}}$ & $\frac{\text { BRANCH }}{\mathrm{kg}}$ & $\frac{\text { STEM }}{\mathrm{kg}}$ & $\frac{\text { TOTAL }}{\mathrm{kg}}$ & AGE \\
\hline \multirow[t]{10}{*}{ DN 34} & 13.8 & 10.25 & 15.49 & 25.21 & 40.70 & \\
\hline & 11.5 & 9.77 & 8.86 & 18.76 & 27.62 & \\
\hline & 10.3 & 9.30 & 6.56 & 15.31 & 21.88 & \\
\hline & 9.5 & 9.12 & 4.19 & 11.26 & 15.46 & \\
\hline & 8.3 & 7.50 & 6.62 & 8.72 & 15.34 & \\
\hline & 3.1 & 3.55 & & & 3.51 & \\
\hline & 2.7 & 3.35 & & & 2.09 & \\
\hline & 2.6 & 3.32 & & & 2.19 & \\
\hline & 1.8 & 2.55 & & & 1.16 & \\
\hline & 1.2 & 2.23 & & & .47 & \\
\hline
\end{tabular}

$\mathrm{NE} \quad \begin{array}{lll}308 & 10.1 & 9.2\end{array}$

$5.3 \quad 5.09$

$\begin{array}{llll}5.21 & 12.45 & 17.66 & 5\end{array}$

$4.2 \quad 4.36$

$5.173 \quad 3$

$4.314 \quad 3$

$3.5 \quad 3.93$

$2.8 \quad 3.30$

$2.0 \quad 2.92$

DN 182

$\begin{array}{ll}8.9 & 8.0 \\ 3.5 & 4.30 \\ 3.3 & 4.22 \\ 2.2 & 3.21 \\ 2.0 & 2.68 \\ 1.6 & 2.24\end{array}$

$8.44 \quad 10.94 \quad 19.38$

$4.786 \quad 3$

$4.286 \quad 3$

$2.173 \quad 3$

$1.489 \quad 3$

.9913

DN $17 \quad 13.7 \quad 10.96$

$\begin{array}{llll}15.16 & 27.64 & 42.80 & 7\end{array}$

$11.7 \quad 11.25$

$10.6 \quad 10.74$

$\begin{array}{llll}7.28 & 22.56 & 29.84 & 7\end{array}$

$\begin{array}{llll}4.99 & 17.37 & 22.37 & 7\end{array}$

$9.4 \quad 10.10$

$4.23 \quad 14.26$

$18.49 \quad 7$

$7.8 \quad 8.10$

5.48

9.25

14.73

2.42

3.70

6.12

$3.957 \quad 3$

$4.2 \quad 4.06$

$3.6 \quad 4.20$

$3.715 \quad 3$

$3.2 \quad 3.88$

$2.850 \quad 3$

$2.5 \quad 3.40$

2.0693

$2.2 \quad 3.08$

1.9

2.83

$1.674 \quad 3$

.7163

$\begin{array}{lll}\text { SIOUX } & 7.5 & 6.7\end{array}$

3.75

5.85

9.60

5 
GRANITE FALIS (1987 plantation)

\begin{tabular}{|c|c|c|c|c|c|c|}
\hline CLONE & $\frac{\mathrm{DBH}}{\mathrm{cm}}$ & $\frac{\mathrm{HGT}}{\mathrm{m}}$ & $\frac{\text { BRANCH }}{\mathrm{kg}}$ & $\frac{\text { STEM }}{\mathrm{kg}}$ & $\frac{\text { TOTAL }}{\mathrm{kg}}$ & $\underline{\text { AGE }}$ \\
\hline \multirow[t]{9}{*}{ DN 34} & 19.3 & 15.65 & 22.63 & 70.53 & 93.16 & 8 \\
\hline & 18.5 & 16.34 & 17.06 & 66.44 & 83.50 & 8 \\
\hline & 17.5 & 15.25 & 15.78 & 56.61 & 72.40 & 8 \\
\hline & 16.0 & 15.05 & 12.43 & 48.97 & 61.39 & 8 \\
\hline & 2.0 & 3.12 & & & .900 & 3 \\
\hline & 3.2 & 4.56 & & & 2.007 & 3 \\
\hline & 4.3 & 5.10 & & & 2.818 & 3 \\
\hline & 5.2 & 5.65 & & & 4.232 & 3 \\
\hline & 6.4 & 6.35 & & & 7.030 & 3 \\
\hline \multirow[t]{5}{*}{$\mathrm{NE} \quad 308$} & 3.2 & 4.61 & & & 1.338 & 3 \\
\hline & 4.1 & 5.76 & & & 2.356 & 3 \\
\hline & 5.0 & 6.33 & & & 3.900 & 3 \\
\hline & 6.8 & 8.17 & & & 7.685 & 3 \\
\hline & 7.6 & 7.41 & & & 9.699 & 3 \\
\hline \multirow[t]{5}{*}{ DN 182} & 3.2 & 3.86 & & & 1.886 & 3 \\
\hline & 4.1 & 5.48 & & & 3.377 & 3 \\
\hline & 5.2 & 5.10 & & & 3.965 & 3 \\
\hline & 6.7 & 6.89 & & & 6.936 & 3 \\
\hline & 7.5 & 7.08 & & & 8.934 & 3 \\
\hline \multirow[t]{5}{*}{ DN 17} & 2.2 & 3.46 & & & 1.015 & 3 \\
\hline & 3.9 & 4.47 & & & 2.616 & 3 \\
\hline & 4.7 & 5.62 & & & 3.216 & 3 \\
\hline & 5.0 & 5.81 & & & 4.722 & \\
\hline & 6.3 & 6.43 & & & 7.320 & \\
\hline
\end{tabular}

FAIRMONT (1986 plantations)

\begin{tabular}{lrrrrrr} 
CLONE & \multicolumn{1}{c}{ DBH } & \multicolumn{1}{c}{$\frac{\text { HGT }}{\mathrm{cm}}$} & $\frac{\text { BRANCH }}{\mathrm{kg}}$ & $\frac{\text { STEM }}{\mathrm{kg}}$ & $\frac{\text { TOTAL }}{\mathrm{kg}}$ & $\frac{\text { AGE }}{}$ \\
SIOUX & 10.2 & 10.23 & & & & \\
$(3 \times 3 \mathrm{~m})$ & 9.1 & 10.67 & & & 25.133 & 3 \\
& 7.2 & 9.60 & & & 18.325 & 3 \\
& 5.5 & 7.76 & & & 6.209 & 3 \\
& 15.2 & 12.71 & 12.38 & 37.56 & 49.935 & 3
\end{tabular}


MILACA (1987 plantations)

\begin{tabular}{|c|c|c|c|c|c|c|}
\hline CIONE & $\frac{\mathrm{DBH}}{\mathrm{cm}}$ & $\frac{\mathrm{HGT}}{\mathrm{m}}$ & $\frac{\text { BRANCH }}{\mathrm{kg}}$ & $\frac{\text { STEM }}{\mathrm{kg}}$ & $\frac{\text { POTAL }}{\mathrm{kg}}$ & AGE \\
\hline \multirow[t]{6}{*}{ NE387 } & 11.4 & 8.5 & 10.89 & 14.30 & 25.19 & 5 \\
\hline & 10.6 & 8.0 & 10.30 & 12.36 & 22.66 & 4 \\
\hline & 9.1 & 7.8 & 6.01 & 9.56 & 15.57 & 4 \\
\hline & 7.4 & 7.2 & 3.59 & 6.46 & 10.05 & 4 \\
\hline & 6.6 & 6.8 & 2.95 & 4.57 & 7.51 & 4 \\
\hline & 5.3 & 5.6 & 2.49 & 3.65 & 6.15 & 4 \\
\hline \multirow[t]{7}{*}{ NE5 4} & 10.3 & 8.6 & 8.28 & 12.15 & 20.43 & 5 \\
\hline & 6.2 & 7.3 & 3.03 & 4.53 & 7.56 & 5 \\
\hline & 10.5 & 8.8 & 9.69 & 13.72 & 23.40 & 4 \\
\hline & 9.5 & 8.6 & 9.98 & 13.12 & 23.11 & 4 \\
\hline & 8.4 & 8.0 & 7.57 & 9.62 & 17.20 & 4 \\
\hline & 6.5 & 7.5 & 3.24 & 4.78 & 8.02 & 4 \\
\hline & 5.7 & 7.3 & 2.58 & 4.25 & 6.84 & 4 \\
\hline \multirow[t]{7}{*}{ DN1 82} & 18.6 & 15.5 & 19.62 & 64.16 & 83.77 & 8 \\
\hline & 16.5 & 15.8 & 12.29 & 48.45 & 60.74 & 8 \\
\hline & 12.2 & 11.1 & 8.28 & 20.30 & 28.58 & 5 \\
\hline & 12.0 & 10.0 & 8.82 & 16.79 & 25.61 & 4 \\
\hline & 10.0 & 9.4 & 6.88 & 13.49 & 20.37 & 4 \\
\hline & 5.8 & 7.6 & 1.74 & 4.35 & 6.09 & 4 \\
\hline & 4.5 & 5.8 & 2.06 & 2.71 & 4.77 & 4 \\
\hline \multirow[t]{5}{*}{ NE308 } & 12.9 & 12.0 & 5.86 & 22.63 & 28.49 & 5 \\
\hline & 12.1 & 9.4 & 7.34 & 16.21 & 23.55 & 4 \\
\hline & 10.2 & 9.0 & 4.41 & 10.72 & 15.13 & 4 \\
\hline & 7.8 & 8.0 & 1.89 & 7.71 & 9.60 & 4 \\
\hline & 5.1 & 6.5 & .63 & 2.84 & 3.45 & 4 \\
\hline \multirow[t]{7}{*}{ DN17 } & 19.95 & 15.97 & 18.81 & 65.52 & 84.33 & 8 \\
\hline & 14.90 & 15.35 & 10.74 & 44.58 & 55.32 & 8 \\
\hline & 13.5 & 11.1 & 9.10 & 24.50 & 33.60 & 5 \\
\hline & 11.1 & 8.9 & 7.52 & 13.77 & 21.28 & 4 \\
\hline & 8.8 & 8.5 & 5.84 & 10.27 & 16.11 & 4 \\
\hline & 5.6 & 7.4 & 1.68 & 4.13 & 5.81 & 4 \\
\hline & 3.6 & 5.0 & .75 & 1.50 & 2.25 & 4 \\
\hline \multirow[t]{5}{*}{ DN34 } & 13.4 & 9.7 & 13.02 & 22.21 & 35.23 & 5 \\
\hline & 9.5 & 7.6 & 6.26 & 9.62 & 15.89 & 4 \\
\hline & 7.2 & 7.4 & 4.10 & 6.87 & 10.97 & 4 \\
\hline & 6.1 & 7.2 & 2.05 & 4.36 & 6.41 & 4 \\
\hline & 3.1 & 5.0 & .50 & 1.20 & 1.70 & 4 \\
\hline
\end{tabular}


MILACA Con't (1987 plantations)

\begin{tabular}{|c|c|c|c|c|c|}
\hline CLONE & $\frac{\mathrm{DBH}}{\mathrm{cm}}$ & $\frac{\text { HGT }}{\mathrm{m}}$ & $\frac{\text { BRANCH }}{\mathrm{kg}}$ & $\frac{\text { STEM }}{\mathrm{kg}}$ & $\frac{\text { TOTAL }}{\mathrm{kg}}$ \\
\hline SIOUX & 13.4 & 11.4 & 7.72 & 21.35 & 29.07 \\
\hline & 8.1 & 8.4 & 4.46 & 8.21 & 12.67 \\
\hline DN 2 & 16.9 & 12.3 & 17.51 & 37.62 & 55.13 \\
\hline DN 5 & 13.3 & 10.9 & 7.16 & 20.94 & 28.10 \\
\hline DN131 & 9.1 & 10.2 & 3.34 & 11.00 & 14.34 \\
\hline NE 222 & 9.8 & 9.6 & 2.99 & 10.61 & 13.60 \\
\hline $145-5 I$ & 12.0 & 9.7 & 5.32 & 16.30 & 21.62 \\
\hline NM 2 & 13.0 & 11.5 & 10.47 & 23.01 & 33.48 \\
\hline
\end{tabular}

SIOUX FALLS (1987 PLANTATION)

$\begin{array}{lrcrrrr}\text { CLONE } & \begin{array}{r}\text { DBH } \\ \mathrm{Cm}\end{array} & \begin{array}{c}\text { HGT } \\ \mathrm{m}\end{array} & \begin{array}{c}\text { BRANCH } \\ \mathrm{kg}\end{array} & \begin{array}{c}\text { STEM } \\ \mathrm{kg}\end{array} & \begin{array}{c}\text { TOTAL } \\ \mathrm{kg}\end{array} & \text { AGE } \\ \text { SIOUX } & 7.0 & 5.4 & 4.20 & 5.67 & 9.87 & 5 \\ \text { NE308 } & 9.0 & 7.2 & 4.10 & 10.93 & 15.03 & 5 \\ \text { DN182 } & 9.0 & 7.4 & 5.32 & 10.96 & 16.28 & 5 \\ \text { DN34 } & 12.2 & 10.31 & 6.93 & 20.42 & 27.35 & 7 \\ \text { DN34 } & 11.0 & 10.13 & 4.81 & 16.34 & 21.05 & 7 \\ \text { DN34 } & 9.9 & 7.4 & 8.02 & 13.31 & 21.33 & 5 \\ \text { DN17 } & 13.6 & 11.05 & 12.10 & 26.94 & 39.04 & 7 \\ \text { DN17 } & 11.5 & 10.55 & 6.62 & 17.43 & 24.05 & 7 \\ \text { DN17 } & 9.1 & 7.5 & 6.05 & 10.74 & 16.80 & 5\end{array}$

FARGO (1987 PLANTATION)

$\begin{array}{lrccccr}\text { CLONE } & \text { DBH } & \text { HGT } & \text { BRANCH } & \text { STEM } & \text { TOTAL } & \text { AGE } \\ & \mathrm{Cm} & \mathrm{m} & \mathrm{kg} & \mathrm{kg} & \mathrm{kg} & \mathrm{Yr} \\ \text { DN182 } & 14.6 & 11.12 & 15.25 & 31.40 & 46.65 & 8 \\ & 15.2 & 10.85 & 11.04 & 33.63 & 44.68 & 8 \\ \text { DN17 } & 16.7 & 11.73 & 12.85 & 36.58 & 49.42 & 8 \\ & 17.7 & 12.15 & 12.50 & 35.80 & 48.30 & 8\end{array}$


MONDOVI (1987 plantation)

\begin{tabular}{|c|c|c|c|c|c|c|}
\hline CLONE & $\frac{\mathrm{DBH}}{\mathrm{cm}}$ & $\frac{\mathrm{HGT}}{\mathrm{m}}$ & $\frac{\text { BRANCH }}{\mathrm{kg}}$ & $\frac{\text { STEM }}{\mathrm{kg}}$ & $\frac{\text { TOTAL }}{\mathrm{kg}}$ & AGE \\
\hline \multirow[t]{5}{*}{ DN182 } & 12.7 & 13.1 & 8.46 & 25.65 & 34.13 & 5 \\
\hline & 11.1 & 10.3 & 8.56 & 17.06 & 25.61 & 4 \\
\hline & 9.4 & 9.9 & 4.02 & 11.25 & 15.27 & 4 \\
\hline & 5.7 & 7.3 & 1.44 & 3.79 & 5.23 & 4 \\
\hline & 3.8 & 5.6 & .71 & 1.81 & 2.52 & 4 \\
\hline \multirow[t]{5}{*}{ NE308 } & 12.0 & 12.4 & 9.51 & 27.23 & 36.74 & 5 \\
\hline & 10.2 & 10.2 & 7.38 & 15.92 & 23.30 & 4 \\
\hline & 8.6 & 10.6 & 2.32 & 9.48 & 11.79 & 4 \\
\hline & 6.8 & 8.9 & 1.63 & 6.19 & 7.82 & 4 \\
\hline & 4.6 & 7.0 & .56 & 2.48 & 3.04 & 4 \\
\hline \multirow[t]{9}{*}{ DN17 } & 17.8 & 17.08 & 16.12 & 62.09 & 78.22 & 7 \\
\hline & 16.3 & 16.73 & 12.15 & 51.89 & 64.04 & 7 \\
\hline & 15.5 & 15.35 & 12.98 & 46.61 & 59.58 & 7 \\
\hline & 14.3 & 16.15 & 9.00 & 38.87 & 47.87 & 7 \\
\hline & 13.1 & 12.80 & 11.60 & 30.03 & 41.63 & 4 \\
\hline & 10.2 & 9.8 & 6.20 & 14.43 & 20.62 & 4 \\
\hline & 8.8 & 9.0 & 3.89 & 9.02 & 12.91 & 4 \\
\hline & 5.2 & 8.0 & .96 & 3.64 & 4.60 & 4 \\
\hline & 3.7 & 5.7 & .50 & 1.51 & 2.02 & 4 \\
\hline \multirow[t]{8}{*}{ DN34 } & 16.8 & 14.50 & 16.20 & 52.36 & 68.56 & 7 \\
\hline & 15.7 & 15.31 & 11.10 & 49.98 & 56.08 & 7 \\
\hline & 14.6 & 15.74 & 11.40 & 44.56 & 55.96 & 7 \\
\hline & 11.2 & 11.3 & 8.38 & 20.27 & 28.65 & 5 \\
\hline & 9.2 & 9.4 & 5.89 & 12.19 & 18.08 & 4 \\
\hline & 8.1 & 8.8 & 3.42 & 8.60 & 12.02 & 4 \\
\hline & 6.1 & 7.4 & 1.63 & 4.47 & 6.10 & 4 \\
\hline & 4.3 & 5.5 & 1.19 & 2.40 & 3.59 & 4 \\
\hline SIOUX & 12.3 & 11.9 & 10.20 & 22.86 & 33.01 & 5 \\
\hline
\end{tabular}


Number of Septoria Isolates Recovered From Each Host Species

\begin{tabular}{lclc} 
Host & Quantity & Host & Quantity \\
\hline & & & \\
Aspen & 20 & DTAC 16 & 20 \\
Diploid aspen & 1 & DTAC 26 & 24 \\
Triploid aspen & 6 & I 45-1 & 4 \\
Balsam poplar & 44 & | 45/51 & 26 \\
Cottonwood & 35 & JACKII 4 & 37 \\
P. alba & 7 & NC 5260 & 19 \\
P. trichocarpa & 59 & NE 17 & 4 \\
Somacione & 6 & NE 19 & 19 \\
Hybrid poplar & 9 & NE 27 & 5 \\
DN 16 & 16 & NE 28 & 17 \\
DN 17 & 2 & NE 41 & 3 \\
DN 19 & 1 & NE 47 & 3 \\
DN 30 & 1 & NE 50 & 4 \\
DN 34 & 23 & NE 51 & 3 \\
DN 55 & 4 & NE 54 & 19 \\
DN 65 & 1 & NE 56 & 27 \\
DN 70 & 26 & NE 242 & 42 \\
DN 74 & 8 & NE 252 & 20 \\
DN 93 & 2 & NE 258 & 5 \\
DN 131 & 3 & NE 299 & 19 \\
DN 160 & 1 & NE 300 & 1 \\
DN 174 & 1 & NE 308 & 38 \\
DN 182 & 2 & NE 351 & 27 \\
DTAC 4 & 1 & NM 2 & 101 \\
DTAC 7 & 17 & NM 6 & 54 \\
DTAC 8 & 1 & SIOUXLAND & 11 \\
DTAC 9 & 3 & $47-174$ & 1 \\
DTAC 10 & 6 & & \\
\hline & & Total & 859
\end{tabular}




\section{Number of Septoria Isolates} Collected at Each Site

\begin{tabular}{|c|c|c|c|}
\hline Location & Quantity & Location & Quantity \\
\hline Canada & & North Dakota & \\
\hline Ontario & 1 & Fargo & 56 \\
\hline lowa & & South Dakota & \\
\hline Ames & 2 & Sioux Falls & 14 \\
\hline Minnesota & & West Coast & \\
\hline Chippewa NF & 2 & Oregon / Washington & 52 \\
\hline $\begin{array}{l}\text { Cloquet } \\
\text { Fairmont }\end{array}$ & $\begin{array}{c}30 \\
7\end{array}$ & Wisconsin & \\
\hline Grand Rapids & 9 & Ashland & 92 \\
\hline Granite Falls & 40 & Mondovi & 102 \\
\hline International Falls & 1 & Rhinelander & 66 \\
\hline Milaca & 328 & & \\
\hline Northome & 1 & & \\
\hline Rosemount & 42 & & \\
\hline Savage & 7 & & \\
\hline St. Paul & 7 & & \\
\hline
\end{tabular}


Geographic Distribution of Septoria spp. Isolate Collection Number of Isolates Recovered at Each Location

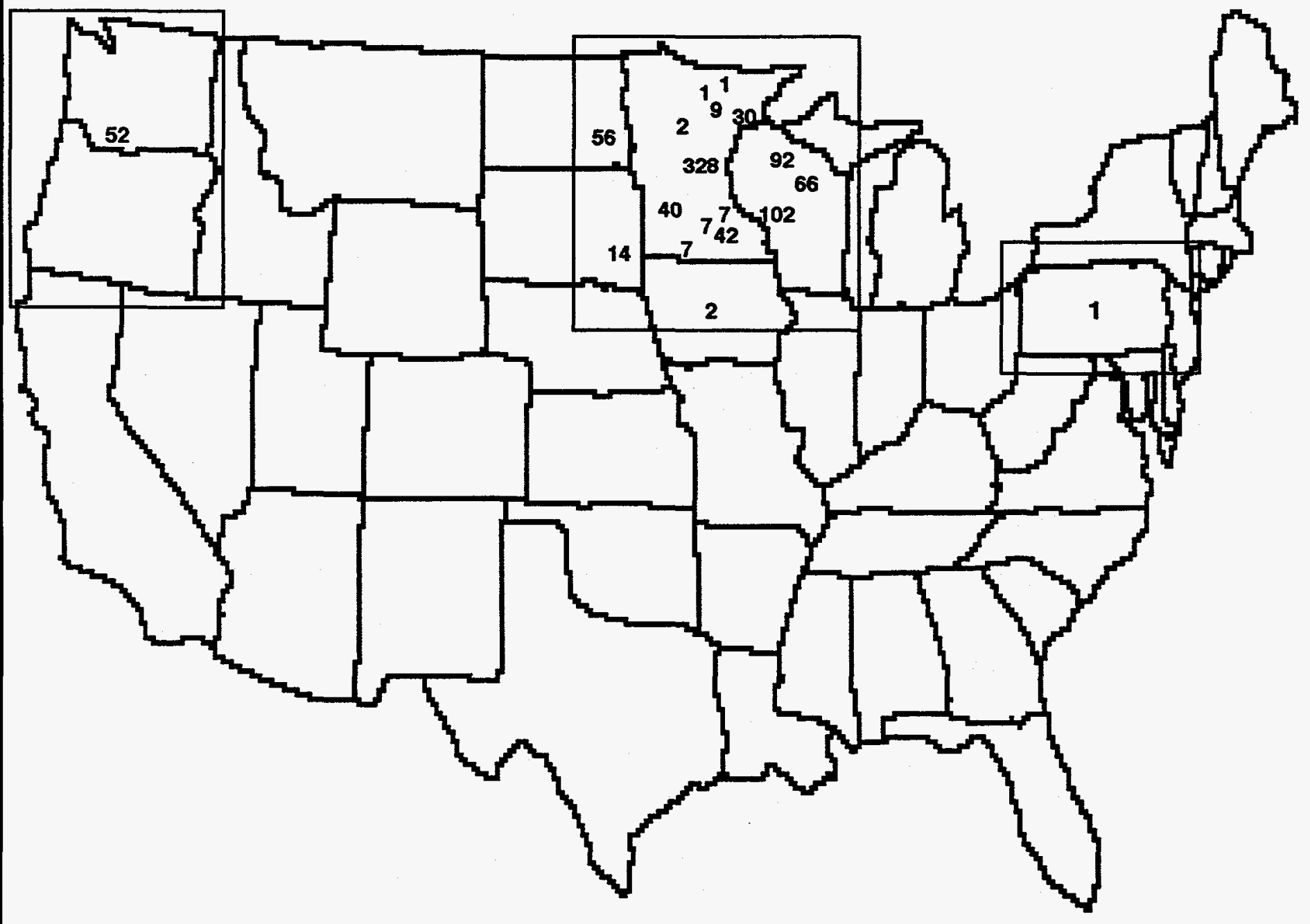




\section{Growth by Diameter Class of 162 Septoria Isolates 13 Days After Inoculation}

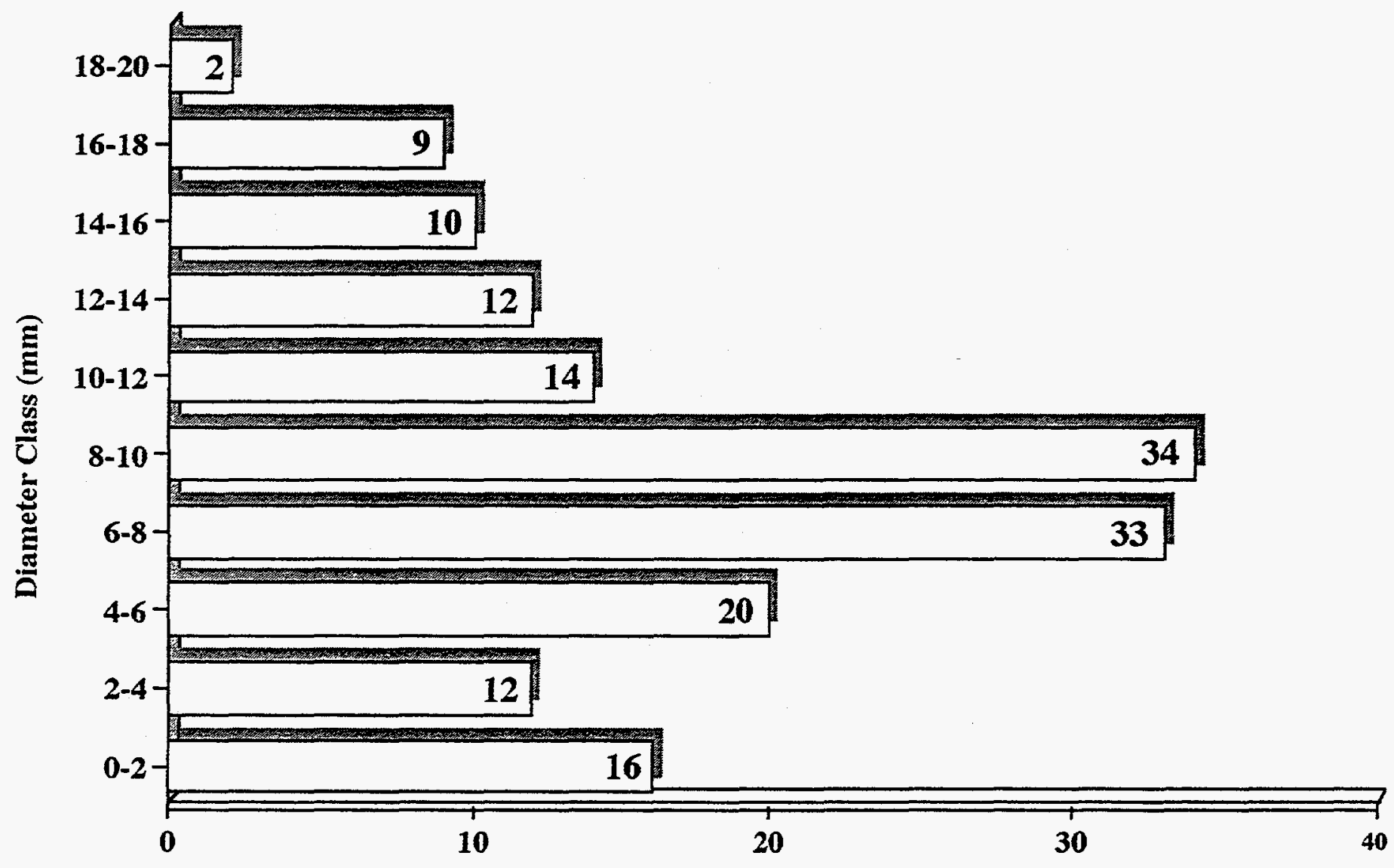

Frequency 
Growth of 162 Septoria spp. Isolates Collected From Different Sites

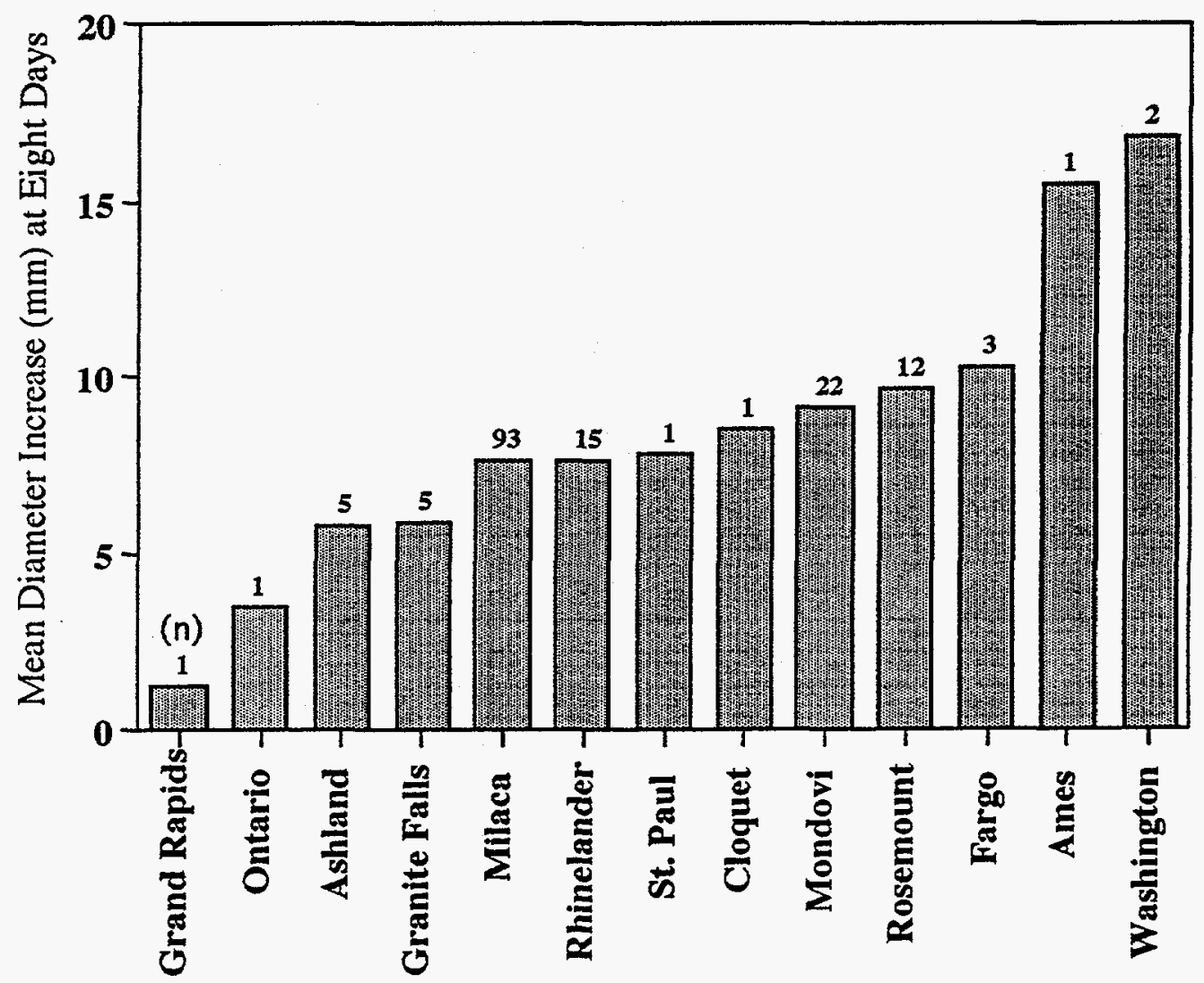


Growth of 162 Septoria spp. Isolates Collected From Various Populus Species and Hybrids

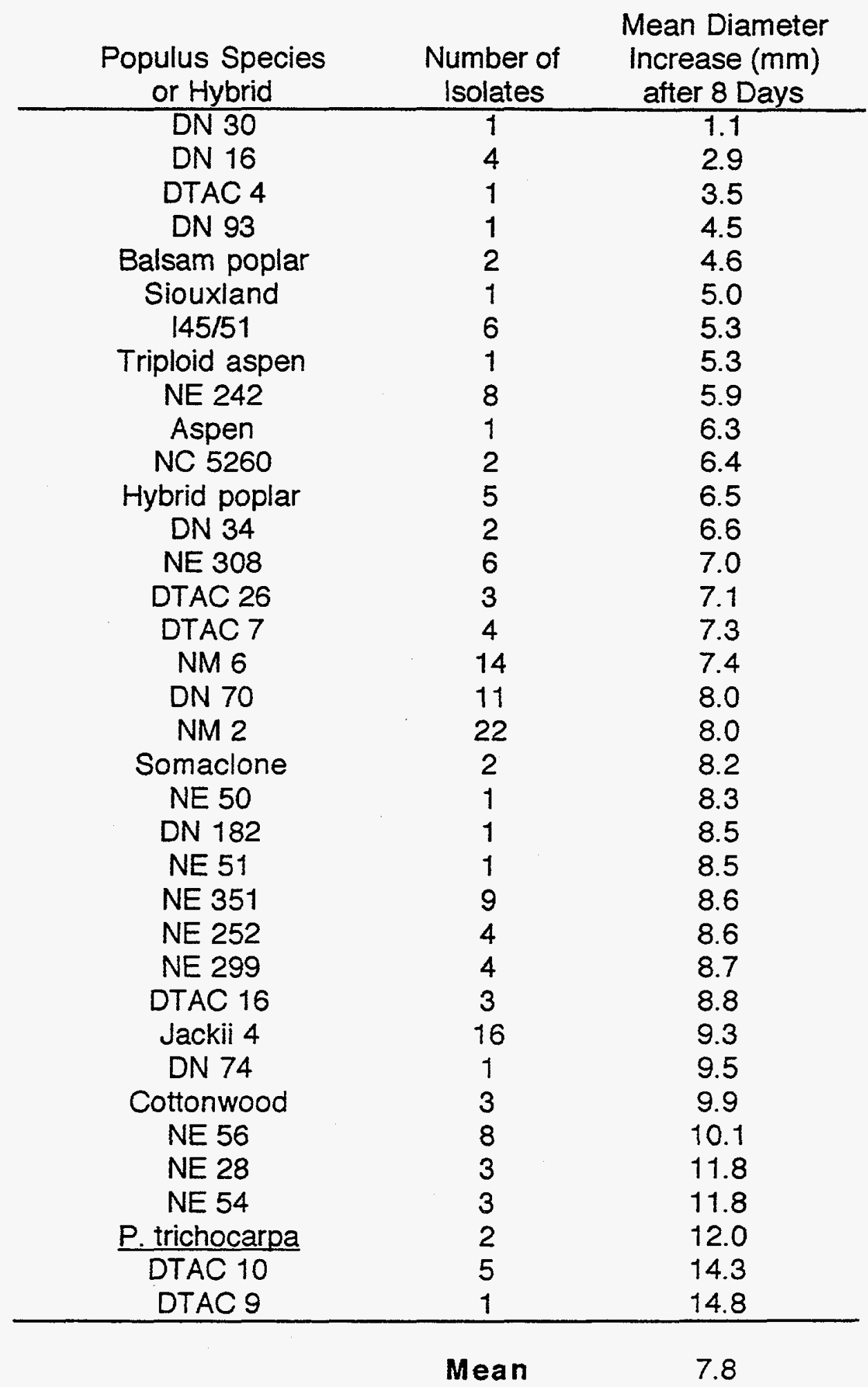




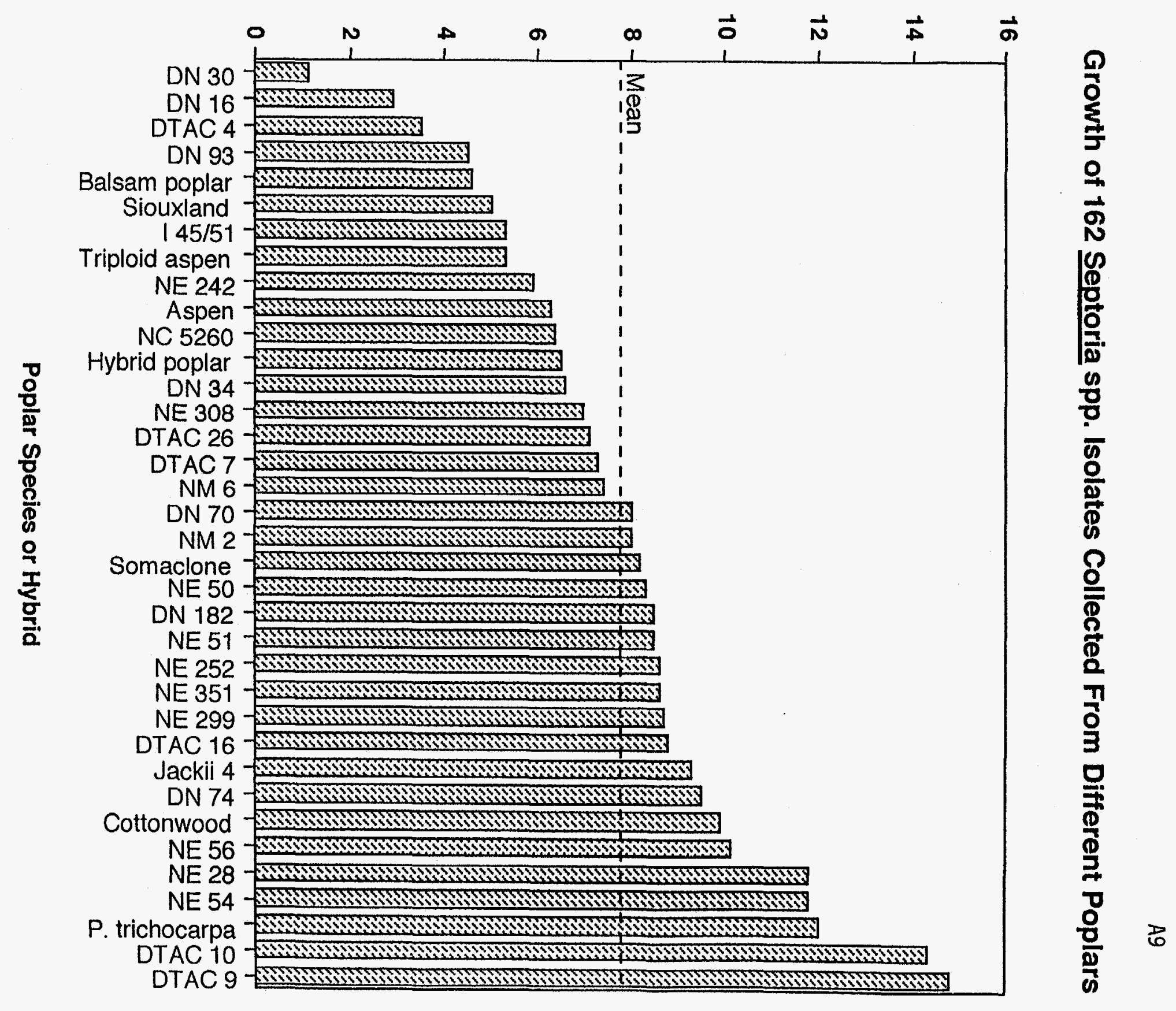


Comparison of Pathogenicity of Different Septoria Isolates using a Leaf Disk Assay

\begin{tabular}{|c|c|c|c|}
\hline$\frac{\text { Septoria }}{\text { Isolate }}$ & $\begin{array}{l}\text { Collection } \\
\text { Location }\end{array}$ & $\begin{array}{c}\text { DN } 34 \text { (resistant) } \\
\text { Leaf Reaction } \\
\text { (\% green at } 32 \text { days) }\end{array}$ & $\begin{array}{c}\text { NE } 299 \text { (susceptible) } \\
\text { Leaf Reaction } \\
\text { (\% green at } 32 \text { days) }\end{array}$ \\
\hline 648 & Pennsylvania & 34 & 24 \\
\hline 523 & Minnesota & 44 & 19 \\
\hline 598 & Wisconsin & 46 & 33 \\
\hline 534 & Minnesota & 49 & 75 \\
\hline 567 & South Dakota & 55 & 37 \\
\hline 599 & Wisconsin & 66 & 87 \\
\hline 514 & Minnesota & 67 & 32 \\
\hline 619 & Oregon & 70 & 6 \\
\hline 486 & Minnesota & 73 & 11 \\
\hline 611 & Minnesota & 75 & 25 \\
\hline SM3 & lowa & 76 & 56 \\
\hline 584 & Minnesota & 76 & 54 \\
\hline 606 & Wisconsin & 77 & 0 \\
\hline 652 & Washington & 80 & 94 \\
\hline 403 & Minnesota & 83 & 4 \\
\hline 589 & Minnesota & 85 & 64 \\
\hline 650 & Wisconsin & 87. & 8 \\
\hline 612 & South Dakota & 88 & 78 \\
\hline 513 & Minnesota & 88 & 41 \\
\hline 379 & Minnesota & 88 & 42 \\
\hline 592 & Minnesota & 89 & 41 \\
\hline 653 & Washington & 92 & 40 \\
\hline 605 & Wisconsin & 92 & 94 \\
\hline 554 & Minnesota & 94 & 77 \\
\hline 488 & Minnesota & 95 & 93 \\
\hline 485 & Minnesota & 96 & 57 \\
\hline \multirow[t]{2}{*}{ SM2 } & lowa & 97 & 42 \\
\hline & Mean & 76 & 46 \\
\hline
\end{tabular}




\section{Stem Inoculation Assay for Pathogenicity}

\begin{tabular}{|c|c|c|c|c|c|}
\hline $\begin{array}{l}\text { Isolate } \\
\text { Number }\end{array}$ & $\begin{array}{l}\text { Recovered } \\
\text { from Clone }\end{array}$ & $\begin{array}{l}\text { Recovered } \\
\text { at Site }\end{array}$ & $\begin{array}{c}\text { Host } \\
\text { Inoculated }\end{array}$ & $\begin{array}{c}\text { Wound } \\
\text { Appearance } \\
\text { at } 14 \text { Days }\end{array}$ & $\begin{array}{l}\text { Wound } \\
\text { Size }(\mathrm{mm} 2) \\
\text { at } 40 \text { Days }\end{array}$ \\
\hline $1461-10$ & NE 56 & Milaca, MN & NE 299 & Dark, sunken & 160 \\
\hline $1467-4$ & NE 252 & Milaca, MN & DN 34 & Dark, sunken & 150 \\
\hline $1481-7$ & NE 242 & Mondovi, WI & DN 34 & Brown, sunken & 120 \\
\hline $1467-4$ & NE 252 & Milaca, MN & NE 299 & Dark, swollen & 120 \\
\hline $1468-7$ & NE 54 & Mondovi, WI & DN 34 & Brown, callussing & 119 \\
\hline $1483-4$ & | 45/51 & Milaca, MN & DN 34 & Dark, open & 105 \\
\hline $1483-4$ & | 45/51 & Milaca, MN & NE 299 & Tan, callussing & 100 \\
\hline $1420-5$ & NE 252 & Ashland, WI & NE 299 & Tan, open & 91 \\
\hline $1468-7$ & NE 54 & Mondovi, WI & NE 299 & Brown, callussing & 78 \\
\hline $1439-4$ & Balsam poplar & Chippewa NF, MN & DN 34 & Dark, sunken & 72 \\
\hline $1462-1$ & NE 28 & Milaca, MN & DN 34 & Clean, open & 70 \\
\hline $1481-7$ & NE 242 & Mondovi, WI & NE 299 & Tan, callussing & 70 \\
\hline $1461-10$ & NE 56 & Milaca, MN & DN 34 & Tan, sunken & 66 \\
\hline $1420-5$ & NE 252 & Ashland, WI & DN 34 & Brown, open & 60 \\
\hline $1480-4$ & NE 308 & Mondovi, WI & NE 299 & Clean, open & 56 \\
\hline $1471-1$ & DN 16 & Milaca, MN & DN 34 & Dark, sunken & 55 \\
\hline $1471-1$ & DN 16 & Milaca, MN & NE 299 & Clean, callussing & 54 \\
\hline $1439-4$ & Balsam poplar & Chippewa NF, MN & NE 299 & Dark, open & 50 \\
\hline Control & none & none & NE 299 & Clean, callussing & 48 \\
\hline $1462-1$ & NE 28 & Milaca, MN & NE 299 & Brown, callussing & 48 \\
\hline $1480-4$ & NE 308 & Mondovi, WI & DN 34 & Dark, callussing & 36 \\
\hline Control & none & none & DN 34 & Clean, callussing & 30 \\
\hline
\end{tabular}




\section{Amplification and Analysis of DNA from Septoria musiva and $\underline{\mathbf{S}}$. populicola Using the Polymerase Chain Reaction (PCR)}

\section{DNA Preparation}

Fungal DNA is prepared according to Goodwin and Lee (1993). DNA concentration for each isolate is quantified using a Hoefer Fluorometer. Preparations are diluted to $1 \mu \mathrm{g} / \mu \mathrm{l}$ DNA concentration.

II. Amplification

Buffer Solution

BRL 10X buffer

dNTP's mixture

(2.5 mM ea. dATP, dGTP, dCTP, dTTP)

Operon primer

Bovine serum albumin

$50 \mathrm{mM} \mathrm{MgCl} 2$

Sterile, distilled water

Total

Fungal DNA

BRL Taq DNA polymerase

\begin{tabular}{l} 
Per Reaction \\
\hline $1.5 \mu 1$ \\
1.2 \\
0.6 \\
1.5 \\
0.6 \\
$\frac{6.95}{12.35 \mu 1}$
\end{tabular}

Per Reaction

$2.5 \mu$

Per Reaction

$0.15 \mu 1$

Multiply amount of each component by the desired number of reactions.

Combine components of buffer solution in a $2.5 \mathrm{ml}$ microcentrifuge tube. Add fungal DNA to each well used in a 96-well thermocycler plate. Add $12.35 \mu \mathrm{l}$ buffer solution to each well. Quickly add Taq. Layer each well with a drop of mineral oil. Place plate in Hybaid Omnigene Thermal Cycler for amplification. Cycling parameters used are $92.5^{\circ} \mathrm{C}$ for $11 / 2 \mathrm{~min}$., $36^{\circ} \mathrm{C}$ for $2 \mathrm{~min}$. and $72^{\circ} \mathrm{C}$ for 2 min., repeated for 45 cycles.

\section{II. Analysis}

Remove plate from cycler and add $3 \mu 16 \mathrm{X}$ loading dye to each well.

Electrophorese in an agarose gel (4.9 g. agarose in $350 \mathrm{ml} .5 X$ TBE buffer). Load a $10 \mathrm{~kb}$ DNA ladder in each gel row for later comparison. Stain gel in TBE with ethidium bromide for 25 minutes. Photograph gel under ultraviolet light.

\section{Reference}

Goodwin, D.C. and S.B. Lee. 1993. Microwave miniprep of total genomic DNA from fungi, plants, protists and animals for PCR. BioTechniques 15(3): 441-444. 
Septoria Culture Collection as of March, 1995

\begin{tabular}{|c|c|c|c|c|}
\hline Isolate & Host & Collection Site & Date & Number \\
\hline SM1 & Hybrid poplar & Ames, IA & & 1 \\
\hline SM3 & Hybrid poplar & Ames, IA & & 1 \\
\hline 488 & Cottonwood & Rosemount, MN & Jul-84 & 1 \\
\hline 513 & Hybrid poplar & Rosemount, MN & May-86 & 1 \\
\hline 602 & P. trichocarpa & Puyallup, WA & Sep-88 & 1 \\
\hline 605 & Hybrid poplar & Rhinelander, WI & Sep-88 & 1 \\
\hline 611 & Hybrid poplar & Rosemount, MN & Oct-88 & 1 \\
\hline 612 & Hybrid poplar & Sioux Falls, SD & Oct-88 & 1 \\
\hline 650 & Hybrid poplar & Rhinelander, WI & Sep-89 & 1 \\
\hline 652 & Hybrid poplar & Puyallup, WA & Oct-89 & 1 \\
\hline 698 & Hybrid poplar & Milaca, MN & Aug-90 & 1 \\
\hline 704 & NE 300 & Rhinelander, WI & Aug-90 & 1 \\
\hline 706 & NE 308 & Ashland, WI & Aug-90 & 1 \\
\hline 734 & DN 65 & Rosemount, MN & Jul-91 & 1 \\
\hline 749 & DTAC 8 & Rosemount, MN & Jul-91 & 1 \\
\hline 769 & NE 27 & Cloquet, MN & Aug-91 & 1 \\
\hline 788 & JACKII 4 & Granite Falls, MN & Aug-91 & 1 \\
\hline 794 & NM 2 & Milaca, MN & Aug-91 & 1 \\
\hline 800 & $145 / 51$ & Ashland, WI & Aug-91 & 1 \\
\hline 900 & JACKII 4 & Milaca, MN & Jun-92 & 11 \\
\hline 902 & NE 242 & Milaca, MN & Jun-92 & 6 \\
\hline 903 & DN 70 & Milaca, MN & Jun-92 & 5 \\
\hline 904 & NE 351 & Milaca, MN & Jun-92 & 2 \\
\hline 905 & DTAC 7 & Milaca, MN & Jun-92 & 2 \\
\hline 906 & NE 54 & Milaca, MN & Jun-92 & 1 \\
\hline 910 & NE 351 & Milaca, MN & Jun-92 & 1 \\
\hline 912 & Aspen & Milaca, MN & Jun-92 & 1 \\
\hline 913 & NE 28 & Milaca, MN & Jun-92 & 7 \\
\hline 914 & NM 2 & Milaca, MN & Jun-92 & 5 \\
\hline 915 & JACKII 4 & Mondovi, WI & Jun-92 & 1 \\
\hline 916 & NE 351 & Mondovi, WI & Jun-92 & 3 \\
\hline 917 & NE 54 & Mondovi, WI & Jun-92 & 3 \\
\hline 918 & NE 56 & Mondovi, WI & Jun-92 & 4 \\
\hline 919 & NE 242 & Mondovi, WI & Jun-92 & 1 \\
\hline 920 & $145-1$ & Mondovi, WI & Jun-92 & 1 \\
\hline 922 & Balsam poplar & Cloquet, MN & Jun-92 & 5 \\
\hline 923 & DTAC 10 & Rosemount, MN & Jun-92 & 6 \\
\hline 924 & DTAC 9 & Rosemount, MN & Jul-92 & 3 \\
\hline 925 & DTAC 7 & Milaca, MN & Jul-92 & 4 \\
\hline 926 & DN 93 & Milaca, MN & Jul-92 & 2 \\
\hline 928 & DN 30 & Milaca, MN & Jul-92 & 1 \\
\hline 929 & NE 351 & Milaca, MN & Jul-92 & 1 \\
\hline 930 & NM 2 & Milaca, MN & Jul-92 & 3 \\
\hline
\end{tabular}




\begin{tabular}{|c|c|c|c|c|}
\hline Isolate & Host & Collection Site & Date & Number \\
\hline 931 & NM 6 & Milaca, MN & Jul-92 & 12 \\
\hline 933 & NE 28 & Milaca, MN & Jul-92 & 2 \\
\hline 934 & NE 351 & Milaca, MN & Jul-92 & 1 \\
\hline 937 & $145 / 51$ & Milaca, MN & Jul-92 & 6 \\
\hline 938 & NE 308 & Milaca, MN & Jul-92 & 2 \\
\hline 939 & NE 242 & Milaca, MN & Jul-92 & 1 \\
\hline 940 & NE 299 & Milaca, MN & Jul-92 & 2 \\
\hline 941 & DN 70 & Milaca, MN & Jul-92 & 8 \\
\hline 942 & DN 16 & Milaca, MN & Jul-92 & 2 \\
\hline 943 & NE 56 & Milaca, MN & Jul-92 & 2 \\
\hline 945 & JACKII 4 & Milaca, MN & Jul-92 & 4 \\
\hline 946 & NE 242 & Milaca, MN & Jul-92 & 5 \\
\hline 947 & NM2 & Milaca, MN & Jul-92 & 17 \\
\hline 948 & JACKII 4 & Mondovi, WI & Jul-92 & 1 \\
\hline 949 & NE 242 & Mondovi, WI & Jul-92 & 3 \\
\hline 950 & $145 / 51$ & Mondovi, WI & Jul-92 & 3 \\
\hline 951 & DTAC 16 & Mondovi, WI & Jul-92 & 1 \\
\hline 952 & NE 56 & Mondovi, WI & Jul-92 & 2 \\
\hline 955 & Balsam poplar & Rhinelander, WI & Aug-92 & 1 \\
\hline 956 & P. trichocarpa & Rhinelander, WI & Aug-92 & 3 \\
\hline 957 & Balsam poplar & Rhinelander, WI & Aug-92 & 9 \\
\hline 958 & P. trichocarpa & Rhinelander, WI & Aug-92 & 4 \\
\hline 959 & P. trichocarpa & Rhinelander, WI & Aug-92 & 1 \\
\hline 960 & Balsam poplar & Northome, MN & Aug-92 & 1 \\
\hline 961 & Aspen & Grand Rapids, MN & Aug-92 & 2 \\
\hline 962 & Balsam poplar & Grand Rapids, MN & Aug-92 & 7 \\
\hline 963 & Aspen & Int'] Falls, MN & Aug-92 & 1 \\
\hline 967 & NM 6 & Milaca, MN & Aug-92 & 2 \\
\hline 970 & NE 50 & Milaca, MN & Aug-92 & 1 \\
\hline 971 & $145 / 51$ & Milaca, MN & Aug-92 & 1 \\
\hline 972 & NM 2 & Milaca, MN & Aug-92 & 8 \\
\hline 973 & NE 242 & Milaca, MN & Aug-92 & 6 \\
\hline 974 & DN 16 & Milaca, MN & Aug-92 & 1 \\
\hline 975 & DTAC 16 & Mondovi, WI & Aug-92 & 3 \\
\hline 977 & JACKII 4 & Mondovi, WI & Aug-92 & 1 \\
\hline 979 & DTAC 26 & Mondovi, WI & Aug-92 & 4 \\
\hline 980 & NE 351 & Mondovi, WI & Aug-92 & 2 \\
\hline 981 & NE 242 & Mondovi, WI & Aug-92 & 1 \\
\hline 983 & NE 56 & Mondovi, WI & Aug-92 & 2 \\
\hline 985 & $145 / 51$ & Fairmont, MN & Aug-92 & 1 \\
\hline 986 & NM 6 & Fairmont, MN & Aug-92 & 3 \\
\hline 992 & Aspen & Milaca, MN & Sep-92 & 1 \\
\hline 994 & DN 34 & Milaca, MN & Sep-92 & 1 \\
\hline 997 & DTAC 16 & Milaca, MN & Sep-92 & 4 \\
\hline 998 & $145 / 51$ & Milaca, MN & Sep-92 & 2 \\
\hline
\end{tabular}




\begin{tabular}{|c|c|c|c|c|}
\hline Isolate & Host & Collection Site & Date & Number \\
\hline 999 & $145-1$ & Milaca, MN & Sep-92 & 3 \\
\hline 1000 & DN 131 & Milaca, MN & Sep-92 & 3 \\
\hline 1003 & DN 19 & Fargo, ND & Sep-92 & 1 \\
\hline 1004 & NE 19 & Fargo, ND & Sep-92 & 9 \\
\hline 1005 & NM 2 & Fargo, ND & Sep-92 & 2 \\
\hline 1006 & DN 55 & Fargo, ND & Sep-92 & 4 \\
\hline 1007 & Cottonwood & Fargo, ND & Sep-92 & 6 \\
\hline 1008 & JACKII 4 & Fargo, ND & Sep-92 & 1 \\
\hline 1009 & NE 252 & Ashland, WI & Sep-92 & 4 \\
\hline 1010 & Siouxland & Ashland, WI & Sep-92 & 8 \\
\hline 1011 & DN 34 & Ashland, WI & Sep-92 & 7 \\
\hline 1013 & NE 258 & Ashland, WI & Sep-92 & 5 \\
\hline 1014 & NE 308 & Ashland, WI & Sep-92 & 2 \\
\hline 1015 & DTAC 26 & Ashland, WI & Sep-92 & 8 \\
\hline 1016 & NE 299 & Ashland, WI & Sep-92 & 5 \\
\hline 1017 & NM 6 & Ashland, WI & Sep-92 & 7 \\
\hline 1018 & DN 174 & Ashland, WI & Sep-92 & 1 \\
\hline 1019 & NM 2 & Ashland, WI & Sep-92 & 7 \\
\hline 1020 & P. alba & Ashland, WI & Sep-92 & 7 \\
\hline 1021 & NE 19 & Ashland, WI & Sep-92 & 10 \\
\hline 1022 & DN 182 & Granite Falls, MN & Sep-92 & 2 \\
\hline 1023 & NE 308 & Granite Falls, MN & Sep-92 & 1 \\
\hline 1024 & DN 34 & Granite Falls, MN & Sep-92 & 3 \\
\hline 1025 & DN 17 & Granite Falls, MN & Sep-92 & 2 \\
\hline 1026 & NE 17 & Granite Falls, MN & Sep-92 & 2 \\
\hline 1027 & Siouxland & Granite Falls, MN & Sep-92 & 3 \\
\hline 1028 & NE 47 & Cloquet, MN & Sep-92 & 3 \\
\hline 1031 & NE 51 & Cloquet, MN & Sep-92 & 1 \\
\hline 1033 & NE 27 & Cloquet, MN & Sep-92 & 4 \\
\hline 1034 & NE 41 & Cloquet, MN & Sep-92 & 1 \\
\hline 1035 & NE 28 & Cloquet, MN & Sep-92 & 2 \\
\hline 1036 & DTAC 26 & Rhinelander, WI & Sep-92 & 2 \\
\hline 1038 & DN 160 & Rhinelander, WI & Sep-92 & 1 \\
\hline 1039 & NM 6 & Rhinelander, WI & Sep-92 & 8 \\
\hline 1040 & DTAC 16 & Rhinelander, WI & Sep-92 & 3 \\
\hline 1041 & NC 5260 & Rhinelander, WI & Sep-92 & 3 \\
\hline 1043 & NM 2 & Rhinelander, WI & Sep-92 & 1 \\
\hline 1044 & DTAC 4 & Ontario, Can. & Sep-92 & 1 \\
\hline 1045 & NE 351 & Milaca, MN & Sep-92 & 2 \\
\hline 1046 & DTAC 7 & Milaca, MN & Sep-92 & 5 \\
\hline 1047 & JACKII 4 & Milaca, MN & Sep-92 & 2 \\
\hline 1048 & NM 6 & Milaca, MN & Sep-92 & 10 \\
\hline 1049 & DN 16 & Milaca, MN & Sep-92 & 7 \\
\hline 1050 & NE 308 & Milaca, MN & Sep-92 & 8 \\
\hline 1051 & DN 70 & Milaca, MN & Sep-92 & 5 \\
\hline
\end{tabular}




\begin{tabular}{|c|c|c|c|c|}
\hline Isolate & Host & Collection Site & Date & Number \\
\hline 1052 & NE 50 & Milaca, MN & Sep-92 & 3 \\
\hline 1053 & NM 2 & Milaca, MN & Sep-92 & 4 \\
\hline 1054 & NE 28 & Milaca, MN & Sep-92 & 3 \\
\hline 1055 & $145 / 51$ & Milaca, MN & Sep-92 & 3 \\
\hline 1057 & NE 299 Somaclone & Rhinelander, WI & Oct-92 & 2 \\
\hline 1059 & NE 299 Somaclone & Rhinelander, WI & Oct-92 & 1 \\
\hline 1060 & NE 299 Somaclone & Rhinelander, WI & Oct-92 & 2 \\
\hline 1063 & NE 299 Somaclone & Rhinelander, WI & Oct-92 & 1 \\
\hline 1064 & DTAC 16 & Milaca, MN & Jul-93 & 1 \\
\hline 1066 & NE 252 & Milaca, MN & Jul-93 & 1 \\
\hline 1067 & NE 351 & Milaca, MN & Jull-93 & 3 \\
\hline 1068 & NE 351 & Milaca, MN & Jul-93 & 1 \\
\hline 1069 & DN 34 & Milaca, MN & Jul-93 & 6 \\
\hline 1070 & NM 2 & Milaca, MN & Jul-93 & 3 \\
\hline 1071 & NE 242 & Milaca, MN & Jul-93 & 2 \\
\hline 1072 & JACKII 4 & Milaca, MN & Jul-93 & 2 \\
\hline 1073 & NE 308 & Milaca, MN & Jul-93 & 3 \\
\hline 1074 & DN 70 & Milaca, MN & Jul-93 & 1 \\
\hline 1076 & NM 6 & Milaca, MN & Jul-93 & 7 \\
\hline 1078 & | $45 / 51$ & Milaca, MN & Jul-93 & 2 \\
\hline 1079 & DN 16 & Milaca, MN & Jul-93 & 2 \\
\hline 1080 & NE 56 & Milaca, MN & Jul-93 & 1 \\
\hline 1083 & NM 2 & Mondovi, WI & Jul-93 & 5 \\
\hline 1085 & NE 351 & Mondovi, WI & Jul-93 & 3 \\
\hline 1086 & NE 252 & Mondovi, WI & Jul-93 & 3 \\
\hline 1087 & DTAC 26 & Mondovi, WI & Jul-93 & 2 \\
\hline 1088 & NE 242 & Mondovi, WI & Jul-93 & 5 \\
\hline 1089 & NM 6 & Mondovi, WI & Jul-93 & 3 \\
\hline 1090 & NE 299 & Mondovi, WI & Jul-93 & 4 \\
\hline 1096 & NE 54 & Mondovi, WI & Aug-93 & 1 \\
\hline 1097 & NM 2 & Mondovi, WI & Aug-93 & 1 \\
\hline 1099 & NE 242 & Mondovi, WI & Aug-93 & 1 \\
\hline 1102 & NE 299 & Mondovi, WI & Aug-93 & 2 \\
\hline 1105 & NE 351 & Mondovi, WI & Aug-93 & 2 \\
\hline 1106 & NE 56 & Mondovi, WI & Aug-93 & 2 \\
\hline 1107 & NE 252 & Mondovi, WI & Aug-93 & 1 \\
\hline 1110 & Triploid aspen & Mondovi, WI & Aug-93 & 4 \\
\hline 1112 & DTAC 26 & Milaca, MN & Aug-93 & 2 \\
\hline 1113 & NM 2 & Milaca, MN & Aug-93 & 3 \\
\hline 1114 & NM 6 & Milaca, MN & Aug-93 & 4 \\
\hline 1115 & DN 16 & Milaca, MN & Aug-93 & 1 \\
\hline 1116 & DTAC 7 & Milaca, MN & Aug-93 & 2 \\
\hline 1117 & JACKII 4 & Milaca, MN & Aug-93 & 2 \\
\hline 1118 & NE 56 & Milaca, MN & Aug-93 & 8 \\
\hline 1120 & DTAC 16 & Milaca, MN & Aug-93 & 2 \\
\hline
\end{tabular}




\begin{tabular}{|c|c|c|c|c|}
\hline Isolate & Host & Collection Site & Date & Number \\
\hline 1121 & NE 299 & Milaca, MN & Aug-93 & 1 \\
\hline 1122 & NE 252 & Milaca, MN & Aug-93 & 2 \\
\hline 1123 & NE 308 & Milaca, MN & Aug-93 & 3 \\
\hline 1124 & NE 54 & Milaca, MN & Aug-93 & 4 \\
\hline 1126 & NE 28 & Milaca, MN & Aug-93 & 1 \\
\hline 1128 & NE 51 & Milaca, MN & Aug-93 & 2 \\
\hline $1131^{\circ}$ & Balsam poplar & St. Paul, MN & Aug-93 & 7 \\
\hline 1135 & Cottonwood & Rosemount, MN & Aug-93 & 2 \\
\hline 1136 & Cottonwood & Rosemount, MN & Aug-93 & 1 \\
\hline 1137 & Triploid aspen & Rosemount, MN & Aug-93 & 2 \\
\hline 1138 & Aspen & Rosemount, MN & Aug-93 & 2 \\
\hline 1139 & JACKII 4 & Rhinelander, WI & Sep-93 & 2 \\
\hline 1140 & NC 5260 & Rhinelander, WI & Sep-93 & 4 \\
\hline 1141 & DTAC 26 & Rhinelander, WI & Sep-93 & 1 \\
\hline 1142 & NE 299 & Rhinelander, WI & Sep-93 & 2 \\
\hline 1143 & NE 242 & Rhinelander, WI & Sep-93 & 4 \\
\hline 1144 & NE 351 & Rhinelander, WI & Sep-93 & 1 \\
\hline 1145 & NE 252 & Rhinelander, WI & Sep-93 & 2 \\
\hline 1146 & NM 2 & Rhinelander, WI & Sep-93 & 4 \\
\hline 1147 & NE 308 & Rhinelander, WI & Sep-93 & 1 \\
\hline 1149 & NM 2 & Fargo, ND & Sep-93 & 8 \\
\hline 1150 & DN 74 & Fargo, ND & Sep-93 & 8 \\
\hline 1151 & Cottonwood & Fargo, ND & Sep-93 & 5 \\
\hline 1152 & Cottonwood & Granite Falls, MN & Sep-93 & 1 \\
\hline 1153 & NM 6 & Granite Falls, MN & Sep-93 & 1 \\
\hline 1154 & JACKII 4 & Fargo, ND & Sep-93 & 3 \\
\hline 1155 & $145 / 51$ & Fargo, ND & Sep-93 & 2 \\
\hline 1156 & NM 6 & Sioux Falls, SD & Sep-93 & 2 \\
\hline 1157 & DN 34 & Granite Falls, MN & Sep-93 & 1 \\
\hline 1158 & NE 308 & Granite Falls, MN & Sep-93 & 5 \\
\hline 1159 & JACKII 4 & Granite Falls, MN & Sep-93 & 4 \\
\hline 1160 & NM 2 & Granite Falls, MN & Sep-93 & 6 \\
\hline 1161 & NC 5260 & Ashland, WI & Sep-93 & 4 \\
\hline 1162 & NE 351 & Ashland, WI & Sep-93 & 2 \\
\hline 1163 & NE 54 & Sioux Falls, SD & Sep-93 & 1 \\
\hline 1165 & NE 242 & Sioux Falls, SD & Sep-93 & 2 \\
\hline 1167 & NM 6 & Sioux Falls, SD & Sep-93 & 2 \\
\hline 1168 & DN 34 & Sioux Falls, SD & Sep-93 & 3 \\
\hline 1169 & DTAC 16 & Sioux Falls, SD & Sep-93 & 1 \\
\hline 1171 & DTAC 7 & Fairmont, MN & Sep-93 & 2 \\
\hline 1172 & NC 5260 & Fairmont, MN & Sep-93 & 1 \\
\hline 1174 & DTAC 16 & Ashland, WI & Sep-93 & 2 \\
\hline 1175 & NE 242 & Ashland, WI & Sep-93 & 2 \\
\hline 1178 & NE 308 & Ashland, WI & Sep-93 & 1 \\
\hline 1179 & NC 5260 & Fargo, ND & Sep-93 & 7 \\
\hline
\end{tabular}




\begin{tabular}{|c|c|c|c|c|}
\hline Isolate & Host & Collection & Date & Number \\
\hline 1181 & DN 34 & Ashland, WI & Sep-93 & 1 \\
\hline 1182 & DN 70 & Granite Falls, MN & Sep-93 & 6 \\
\hline 1183 & DTAC 7 & Granite Falls, MN & Sep-93 & 2 \\
\hline 1184 & P. trichocarpa & West Coast & Sep-93 & 2 \\
\hline 1187 & P.trichocarpa & West Coast & Sep-93 & 1 \\
\hline 1188 & P. trichocarpa & West Coast & Sep-93 & 4 \\
\hline 1189 & P. trichocarpa & West Coast & Sep-93 & 1 \\
\hline 1193 & P. trichocarpa & West Coast & Sep-93 & 2 \\
\hline 1197 & P. trichocarpa & West Coast & Sep-93 & 1 \\
\hline 1198 & P. trichocarpa & West Coast & Sep-93 & 1 \\
\hline 1199 & P. trichocarpa & West Coast & Sep-93 & 3 \\
\hline 1400 & P. trichocarpa & West Coast & Sep-93 & 1 \\
\hline 1401 & P. trichocarpa & West Coast & Sep-93 & 2 \\
\hline 1404 & P. trichocarpa & West Coast & Sep-93 & 2 \\
\hline 1405 & P. trichocarpa & West Coast & Sep-93 & 2 \\
\hline 1406 & Balsam Poplar & Cloquet, MN & Sep-93 & 2 \\
\hline 1414 & NE 41 & Ashland, WI & Sep-93 & 2 \\
\hline 1418 & NE 17 & Sioux Falls, SD & Sep-93 & 2 \\
\hline 1420 & NE 252 & Ashland, WI & Sep-93 & 5 \\
\hline 1427 & P. trichocarpa & West Coast & Sep-93 & 1 \\
\hline 1430 & NM 2 & Mondovi, WI & Sep-93 & 2 \\
\hline 1431 & Diploid aspen & Milaca, MN & Sep-93 & 1 \\
\hline 1432 & JACKII 4 & Milaca, MN & Sep-93 & 2 \\
\hline 1433 & Aspen & Milaca, MN & Sep-93 & 1 \\
\hline 1435 & DTAC 26 & Milaca, MN & Sep-93 & 4 \\
\hline 1437 & NM 2 & Milaca, MN & Sep-93 & 2 \\
\hline 1438 & NE 54 & Milaca, MN & Sep-93 & 5 \\
\hline 1439 & Balsam Poplar & Chippewa NF & Sep-93 & 2 \\
\hline 1440 & NE 308 & Milaca, MN & Sep-93 & 1 \\
\hline 1441 & NE 28 & Mondovi, WI & Sep-93 & 1 \\
\hline 1442 & NM 6 & Milaca, MN & Sep-93 & 2 \\
\hline 1444 & P. trichocarpa & West Coast & Sep-93 & 2 \\
\hline 1445 & P. trichocarpa & West Coast & Sep-93 & 1 \\
\hline 1446 & P. trichocarpa & West Coast & Sep-93 & 2 \\
\hline 1447 & P. trichocarpa & West Coast & Sep-93 & 3 \\
\hline 1450 & P.trichocarpa & West Coast & Sep-93 & 4 \\
\hline 1451 & P. trichocarpa & West Coast & Sep-93 & 2 \\
\hline 1452 & P. trichocarpa & West Coast & Sep-93 & 3 \\
\hline 1453 & P. trichocarpa & West Coast & Sep-93 & 2 \\
\hline 1455 & P. trichocarpa & West Coast & Sep-93 & 1 \\
\hline 1457 & P. trichocarpa & West Coast & Sep-93 & 3 \\
\hline 1460 & P. trichocarpa & West Coast & Sep-93 & 4 \\
\hline 1461 & NE 56 & Milaca, MN & Sep-93 & 4 \\
\hline 1462 & NE 28 & Milaca, MN & Sep-93 & 1 \\
\hline 1467 & NE 252 & Milaca, MN & Sep-93 & 1 \\
\hline
\end{tabular}




\begin{tabular}{cllcc} 
Isolate & Host & Collection Site & Date & Number \\
\hline 1468 & NE 54 & Mondovi, WI & Sep-93 & 4 \\
1469 & NE 299 & Milaca, MN & Sep-93 & 3 \\
1473 & NE 252 & Mondovi, WI & Sep-93 & 1 \\
1475 & DTAC 26 & Milaca, MN & Sep-93 & 1 \\
1476 & DN 34 & Milaca, MN & Sep-93 & 1 \\
1478 & NE 56 & Mondovi, WI & Sep-93 & 1 \\
1479 & NE 351 & Milaca, MN & Sep-93 & 1 \\
1480 & NE 308 & Mondovi, WI & Sep-93 & 5 \\
1481 & NE 242 & Mondovi, WI & Sep-93 & 2 \\
1482 & NE 351 & Mondovi, WI & Sep-93 & 1 \\
1483 & I 45/51 & Milaca, MN & Sep-93 & 5 \\
1485 & DTAC 16 & Milaca, MN & Aug-94 & 3 \\
1486 & Balsam poplar & Milaca, MN & Aug-94 & 3 \\
1489 & DN 70 & Milaca, MN & Aug-94 & 1 \\
1490 & NE 242 & Milaca, MN & Aug-94 & 1 \\
1491 & DN 16 & Milaca, MN & Aug-94 & 1 \\
1495 & NM 6 & Milaca, MN & Aug-94 & 3 \\
1496 & NE 308 & Milaca, MN & Aug-94 & 4 \\
1497 & NM 2 & Milaca, MN & Aug-94 & 2 \\
1499 & NM 2 & Mondovi, WI & Sep-94 & 5 \\
1507 & DN 16 & Mondovi, WI & Sep-94 & 2 \\
1508 & NE 351 & Mondovi, WI & Sep-94 & 1 \\
1509 & NE 308 & Mondovi, WI & Sep-94 & 1 \\
1510 & NE 56 & Mondovi, WI & Sep-94 & 1 \\
1511 & Balsam poplar & Cloquet, MN & Sep-94 & 3 \\
1512 & Cottonwood & Savage, MN & Sep-94 & 7 \\
1513 & Aspen & Cloquet, MN & Sep-94 & 5 \\
1514 & Aspen & Rosemount, MN & Sep-94 & 7 \\
1515 & Cottonwood & Rosemount, MN & Sep-94 & 12 \\
1516 & Balsam poplar & Rosemount, MN & Sep-94 & 1 \\
1519 & $47-174$ & Rosemount, MN & Sep-94 & 1 \\
1523 & Balsam poplar & Cloquet, MN & Sep-94 & 3 \\
\hline & & & Total & 859
\end{tabular}


1. $10 \mathrm{~kb}$ ladder

2. 1035-2, NE 28, Cloquet, MN

3. 1041-5, NC 5260, Rhinelander, WI

4. 1043-1, NM 2, Rhinelander, WI

5. 1045-11, NE 351, Milaca, MN

6. 1046-19, DTAC 7, Milaca, MN

7. 1047-13, Jackii 4, Milaca, MN

8. 1048-5, NM 6, Milaca, MN

9. 1049-8, DN 16, Milaca, MN

10. 1050-2, NE 308, Milaca, MN

11. 1052-5, NE 50, Milaca, MN

12. 1067-5, NE 351, Milaca, MN

13. 1069-1, DN 34, Milaca, MN

14. 1078-9, I 45/51, Milaca, MN

15. 1079-8, DN 16, Milaca, MN

16. 1083-6, NM 2, Mondovi, MN

17. 1086-10, NE 252, Milaca, MN

18. 1088-2, NE 242, Mondovi, WI

19. non-Septoria control

20. non-Septoria control

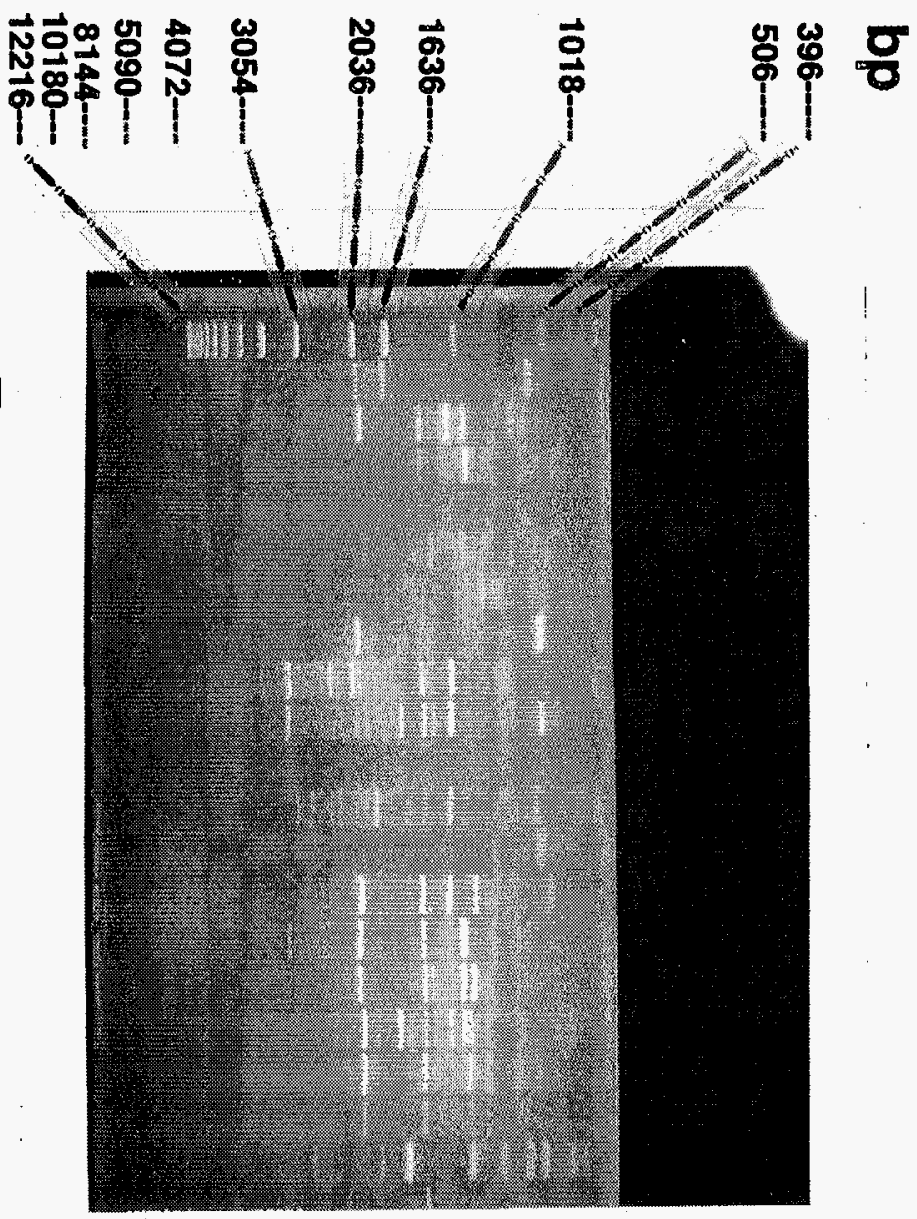

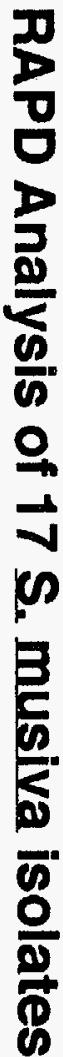




\section{Results of RAPD Analyses of Septoria Isolates}

DNA Operon Primer 10 (5'GGAAGCTTGG3')

SIZE ISOLATES

(bP) $1439-4 \quad 1439-5 \quad 1172-6 \quad 1027-9 \quad 1182-6 \quad 1068-2 \quad 1073-3 \quad 1114-6 \quad 1116-6 \quad 1117-8 \quad 1118-9$ 1123-6 $1431-1$ 506

634

698

762

826

890

954

1,018

1,172

1,327

1,482

1,636

1,836

1,936

2,036

2,290

2,545

2,800

3,054

3,563

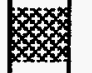

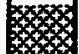

ग)

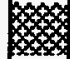
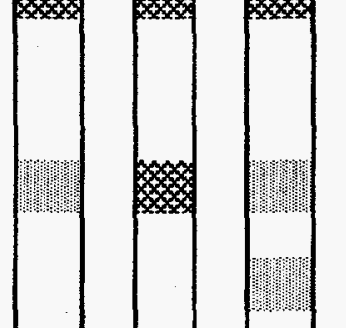

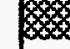

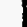

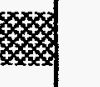

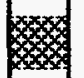
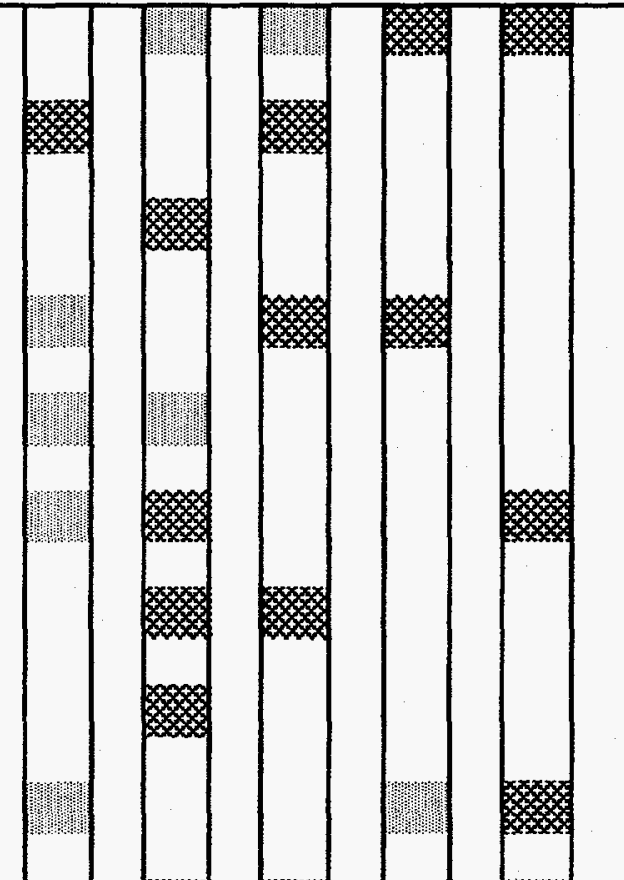

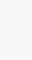







DNA

SIZE

ISOLATES

(bp) $\quad 957-5 \quad 958-2 \quad 1149-3 \quad 1151-4 \quad 1151-5 \quad 1155-10 \quad 1179-6 \quad 1168-1 \quad 1169-3 \quad 1184-8 \quad 1193-6 \quad 1193-9$ 1198-3

506

634

698

762

826

890

954

1,018

1,172

1,327

1,482

1,636

1,836

1,936

2,036

2,290

2,545

2,800

3,054

3,563

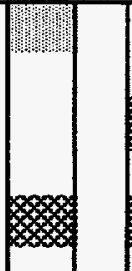

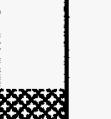
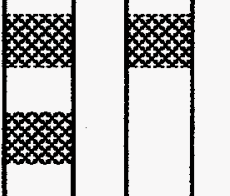

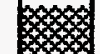

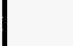

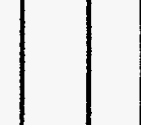

WIII

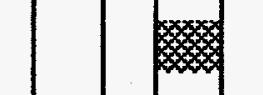

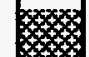

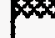
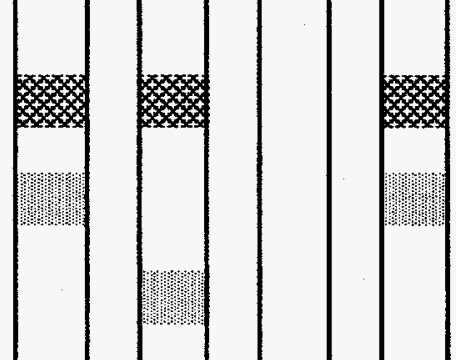

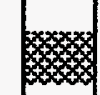
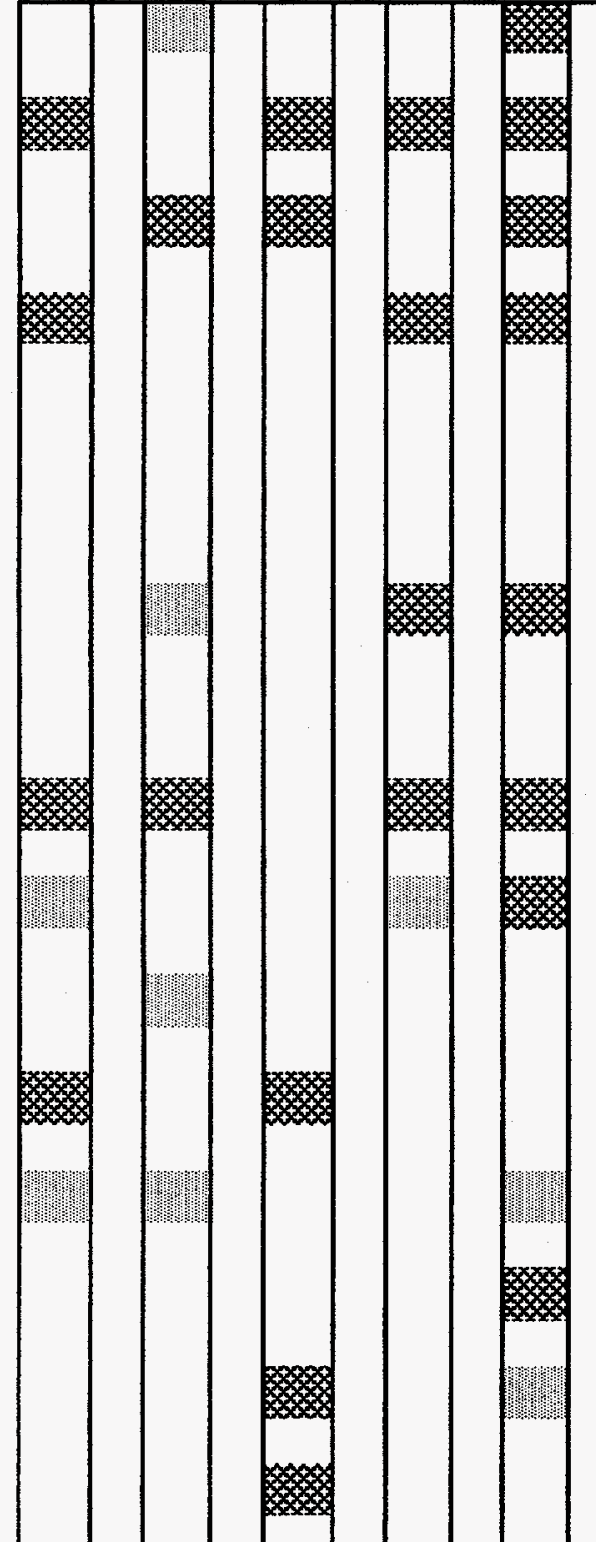

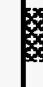

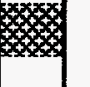

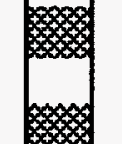

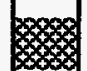

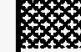

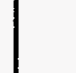

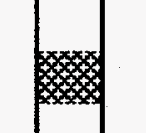
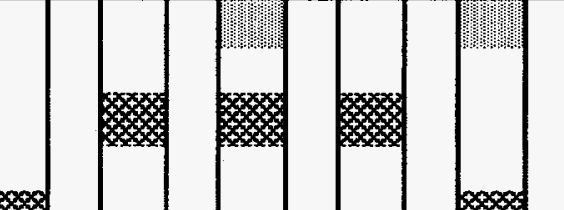

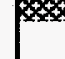

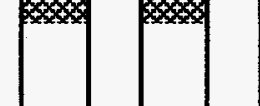

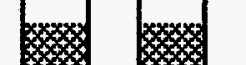

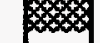
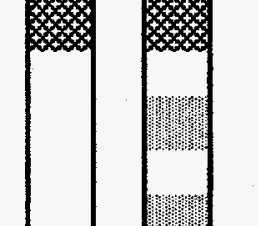

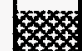

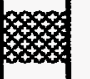

${ }^{m}$

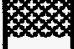

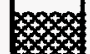

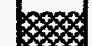

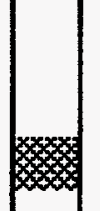
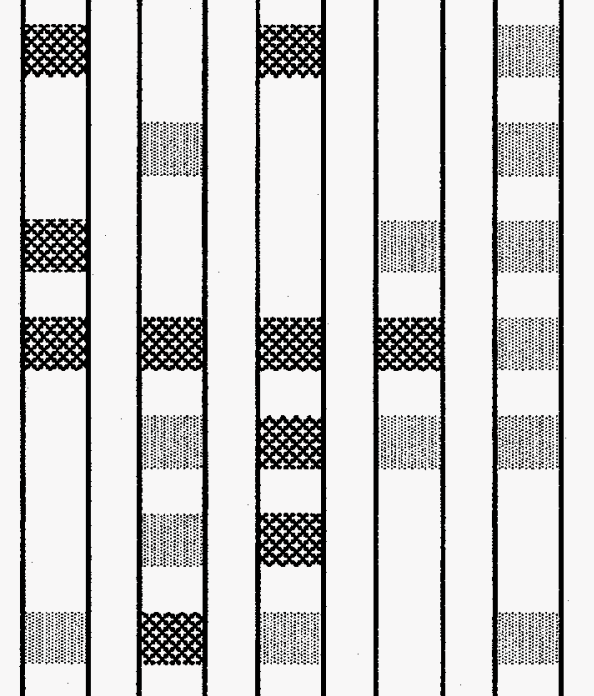

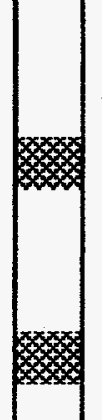

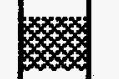

3

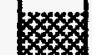
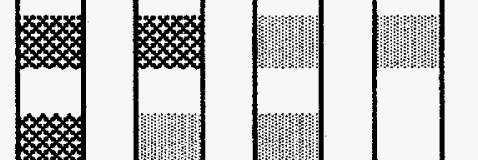

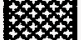

)

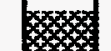

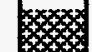

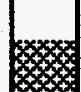

$+$
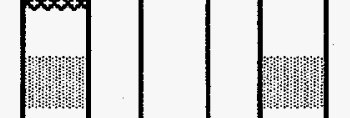

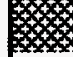

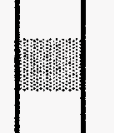

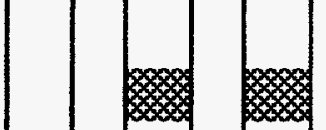




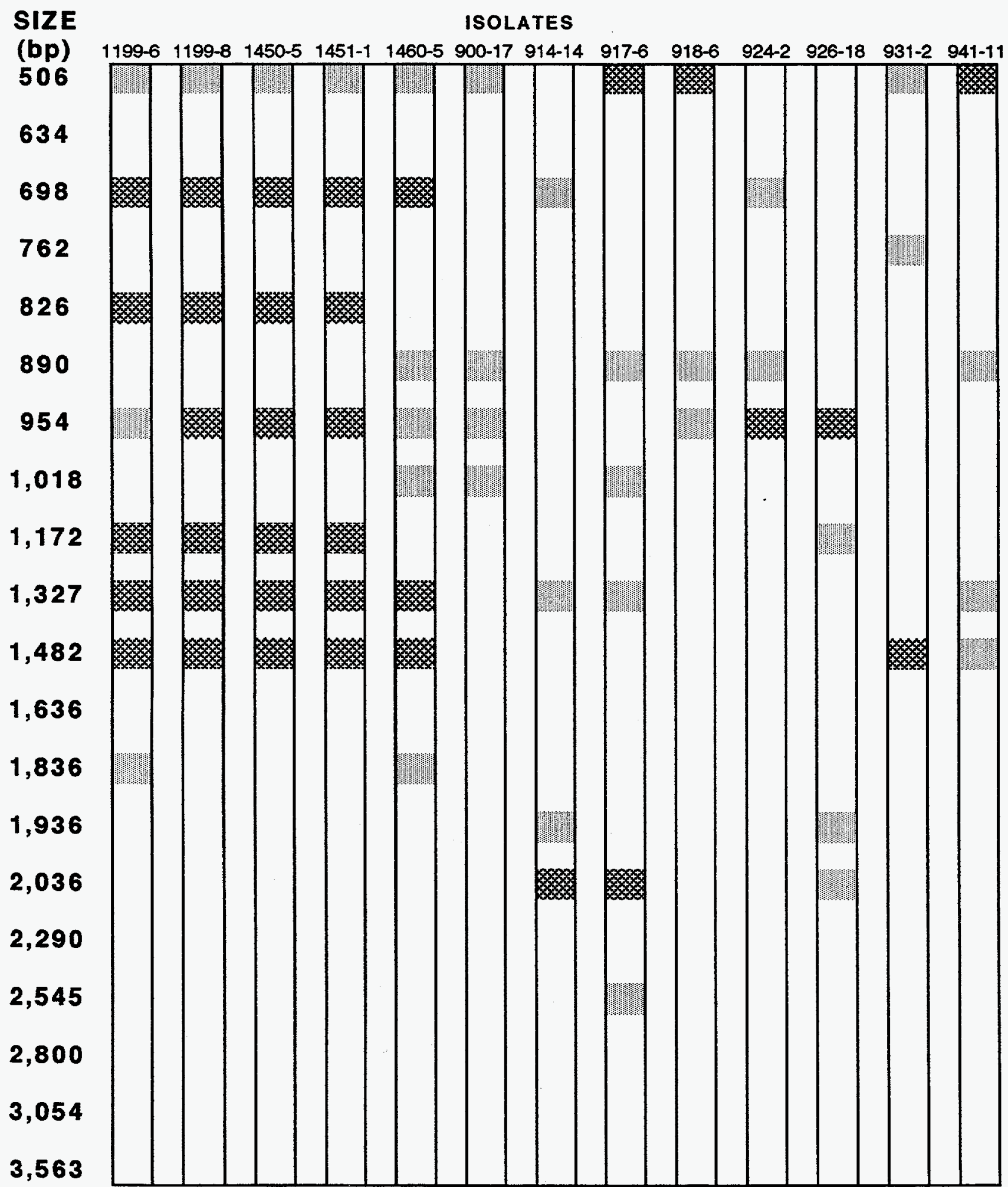




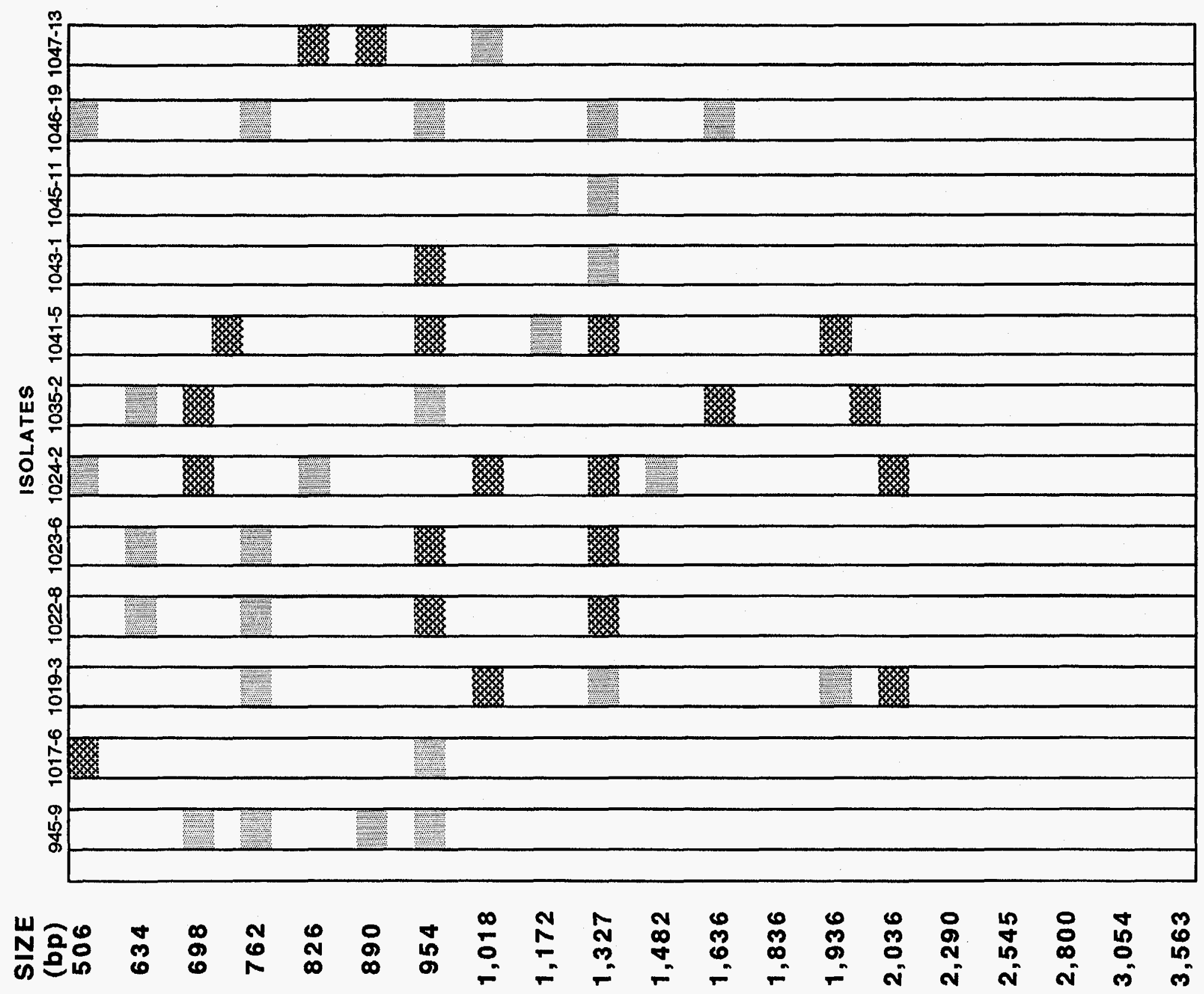




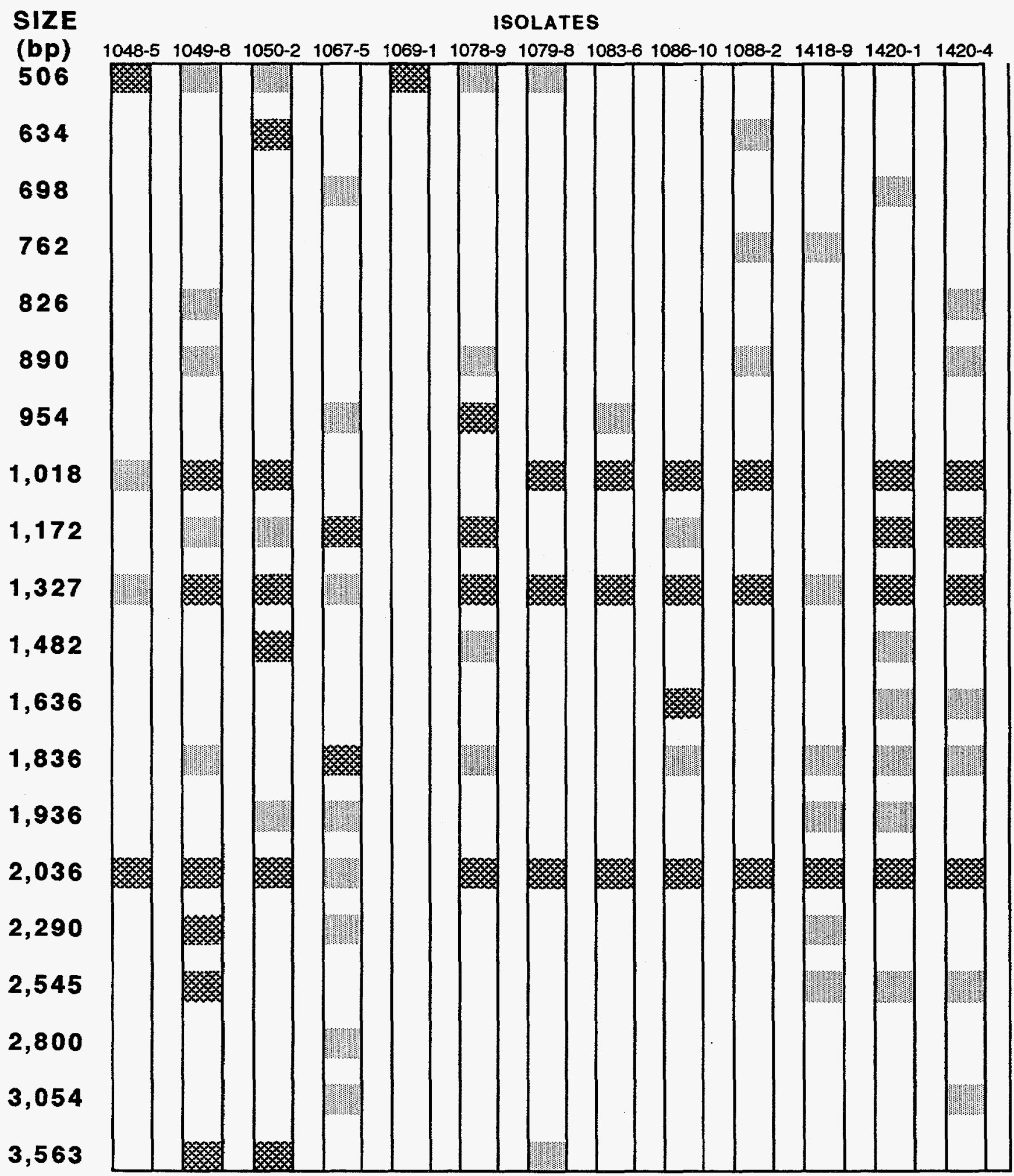


SIZE

(bP) $\quad 1420-5 \quad 1432-2 \quad 1435-3 \quad 1435-6 \quad 1437-4 \quad 1442-6 \quad 1442-7 \quad 14$ 506

634

698

762

826

890

954

1,018

1,172

1,327

1,482

1,636

1,836

1,936

2,036

2,290

2,545

2,800

3,054

3,563

4,072

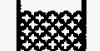

II

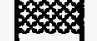
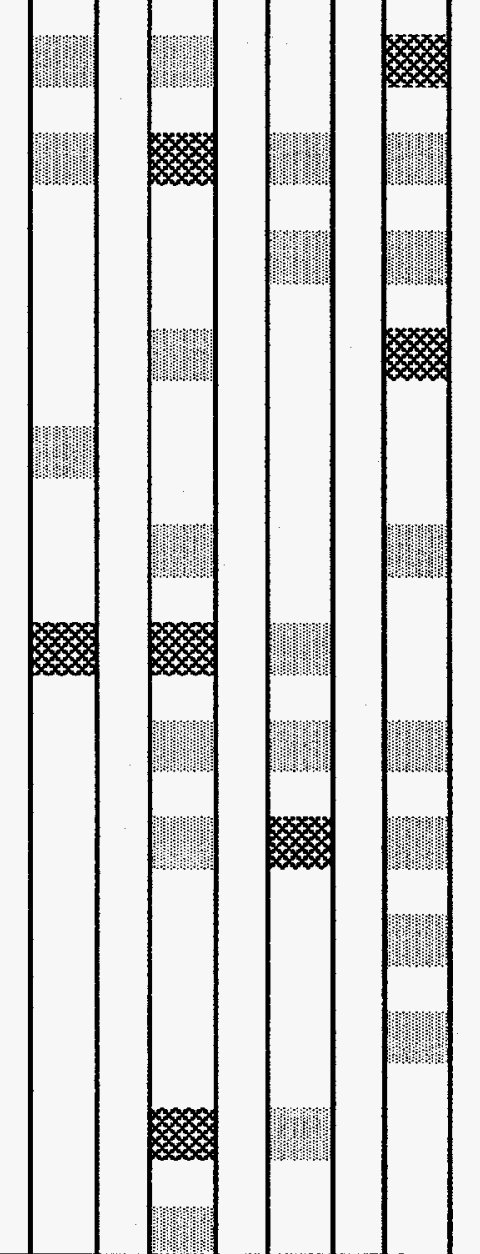

ISOLATES

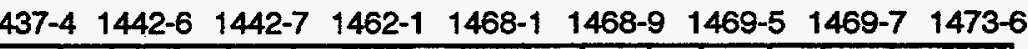
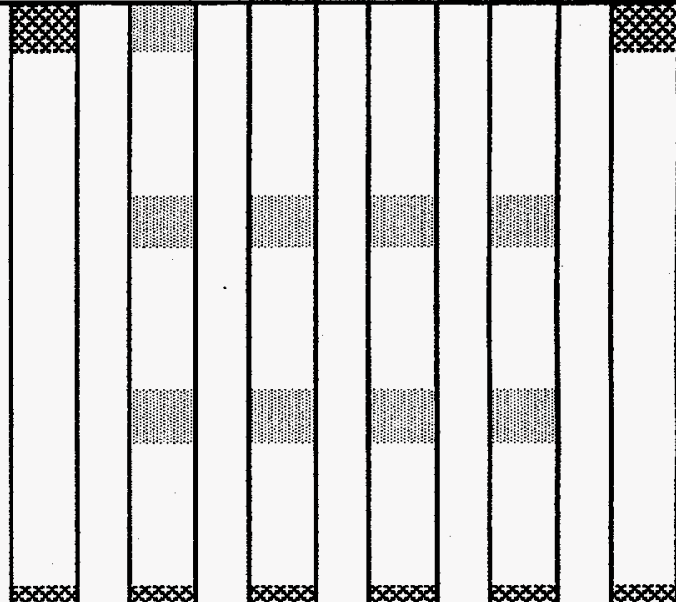

$x$

我

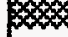

.

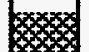

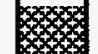

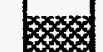

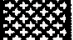

奖
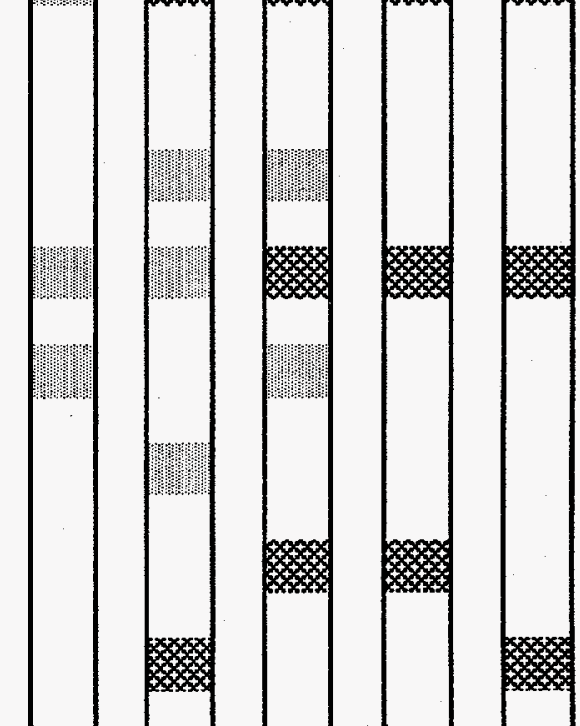

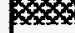
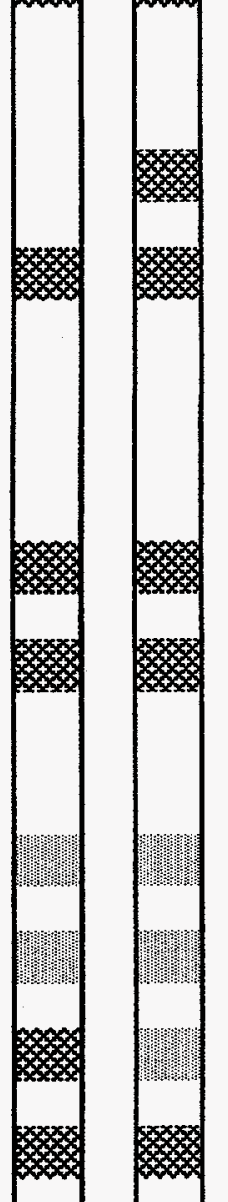


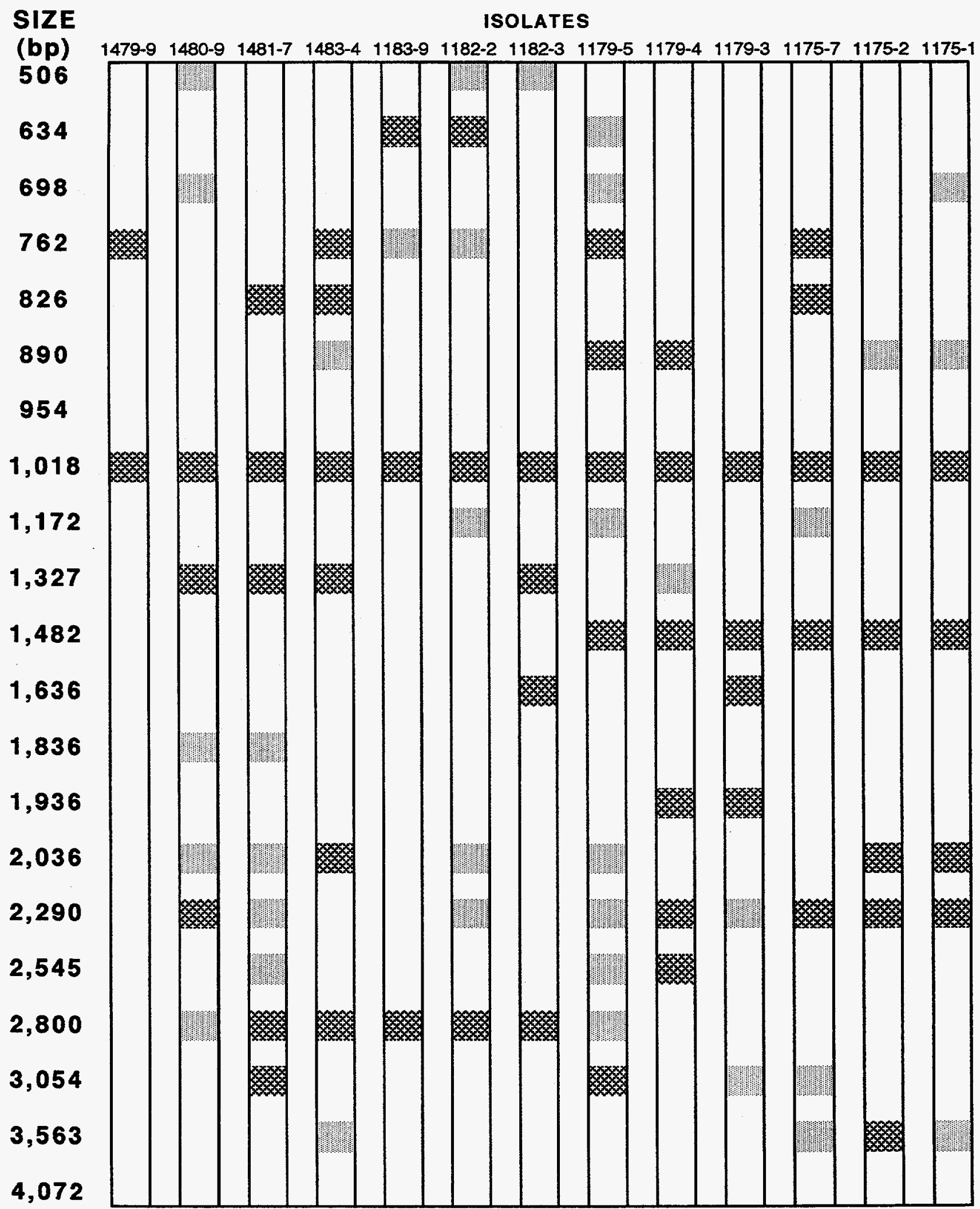


SIZE

ISOLATES

(bp) $\quad 1174-10 \quad 1171-3 \quad 1168-2 \quad 1167-9 \quad 1161-10 \quad 1160-2 \quad 1158-3 \quad 1157-2 \quad 1155-2 \quad 1151-5 \quad 1151-2 \quad 1150-6 \quad 1150-5$ 506

634

698

762

826

890

954

1,018

1,172

1,327

1,482

1,636

1,836

1,936

2,036

2,290

2,545

2,800

3,054

3,563

4,072

.

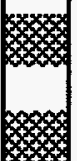

$x$

x

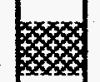

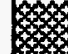

(1)

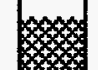

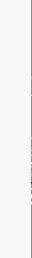
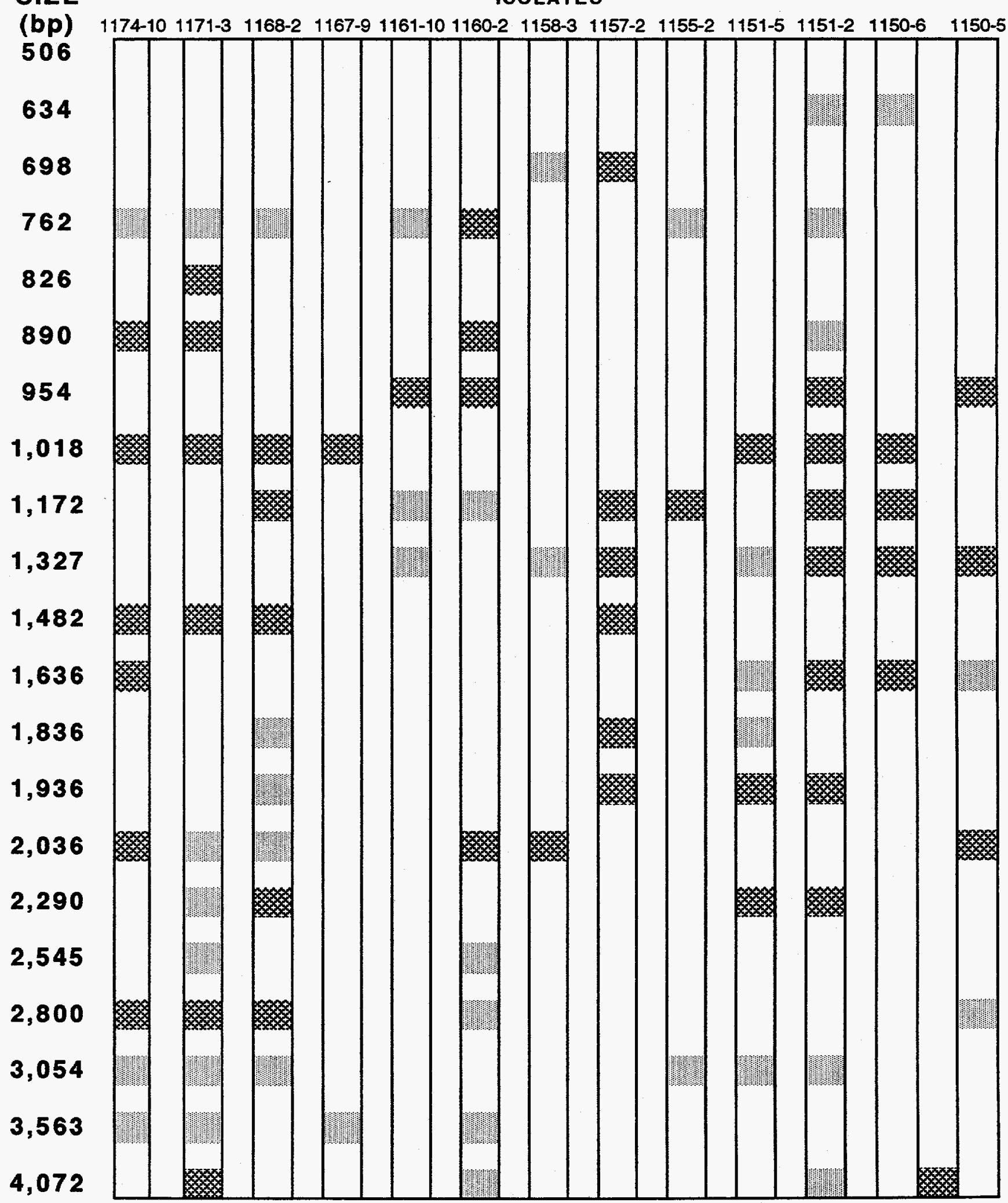





DNA

SIZE

ISOLATES

(bp) 1135-2 1128-2 1123-4

506

634

698

762

826

890

954

1,018

1,172

1,327

1,482

1,636

1,836

1,936

2,036

2,290

2,545

2,800

3,054

3,563

4,072

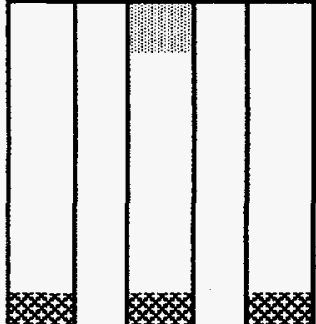

× 
Example of Results from Leaf Disk Bioassay for Septoria Leaf Spot Resistance of NE 308

(\% green leaf area remaining after inoculation)

$\begin{array}{ccccccccc}\text { TRIAL \# } & \text { DAY 4 } & \text { DAY } 8 & \text { DAY 12 } & \text { DAY 16 } & \text { DAY 20 } & \text { DAY 24 } & \text { DAY 28 } & \text { DAY 32 } \\ 193 & 100 & 92 & 76 & 69 & 51 & 32 & 32 & 21 \\ 196 & 98 & 35 & 22 & 9 & 7 & 5 & 4 & 2 \\ 197 & 100 & 100 & 77 & 67 & 68 & 60 & 54 & 45 \\ 198 & 100 & 99 & 76 & 59 & 51 & 46 & 39 & 34 \\ 199 & 99 & 99 & 93 & 86 & 80 & 72 & 59 & 54 \\ 200 & 100 & 87 & 74 & 50 & 37 & 29 & 28 & 27 \\ 201 & 100 & 98 & 94 & 83 & 83 & 82 & 76 & 75 \\ 202 & 100 & 100 & 97 & 94 & 65 & 37 & 33 & 27 \\ 203 & 100 & 100 & 99 & 96 & 71 & 64 & 51 & 47 \\ 204 & 99 & 99 & 87 & 83 & 52 & 58 & 35 & 22 \\ 205 & 100 & 58 & 23 & 10 & 3 & 1 & 0 & 0 \\ 206 & 100 & 100 & 98 & 92 & 87 & 76 & 66 & 50 \\ 207 & 100 & 89 & 77 & 52 & 42 & 36 & 11 & 7 \\ 208 & 100 & 98 & 87 & 59 & 31 & 7 & 1 & 0 \\ 209 & 100 & 72 & 47 & 39 & 38 & 27 & 28 & 21 \\ 210 & 100 & 97 & 95 & 90 & 76 & 66 & 49 & 43 \\ 211 & 99 & 89 & 70 & 56 & 49 & 43 & 38 & 32 \\ 212 & 99 & 95 & 93 & 92 & 84 & 65 & 55 & 50 \\ 213 & 99 & 91 & 57 & 44 & 46 & 43 & 38 & 39 \\ 214 & 100 & 84 & 60 & 61 & 53 & 44 & 37 & 35 \\ 215 & 99 & 68 & 48 & 47 & 36 & 16 & 22 & 17 \\ 216 & 100 & 97 & 90 & 86 & 72 & 64 & 59 & 55 \\ 217 & 100 & 96 & 91 & 90 & 81 & 74 & 67 & 48 \\ 218 & 100 & 56 & 39 & 31 & 25 & 17 & 14 & 10 \\ 219 & 100 & 93 & 74 & 69 & 61 & 56 & 47 & 43 \\ 220 & 97 & 97 & 72 & 54 & 47 & 43 & 27 & 26 \\ 221 & 99 & 94 & 62 & 37 & 16 & 0 & 0 & 0 \\ 222 & 99 & 87 & 61 & 50 & 28 & 4 & 1 & 0 \\ 224 & 98 & 87 & 78 & 68 & 52 & 49 & 40 & 37 \\ 225 & 100 & 99 & 96 & 94 & 92 & 87 & 75 & 58 \\ 226 & 98 & 90 & 81 & 70 & 45 & 28 & 16 & 14 \\ 227 & 98 & 79 & 58 & 37 & 24 & 15 & 6 & 6 \\ 228 & 99 & 90 & 73 & 60 & 62 & 42 & 33 & 26 \\ 229 & 99 & 79 & 59 & 35 & 25 & 19 & 12 & 7 \\ 230 & 100 & 83 & 65 & 60 & 45 & 34 & 33 & 24 \\ 231 & 99 & 77 & 54 & 49 & 31 & 24 & 18 & 12 \\ & 99.39 & 87.61 & 72.31 & 61.89 & 50.44 & 40.70 & 33.44 & 28.17\end{array}$


Leaf Disk Bioassay Results of Tissue Culture-Derived NE 308 Somaclones with Increased Septoria Leaf Spot Resistance

(\% green leaf area remaining after inoculation)

\begin{tabular}{|c|c|c|c|c|c|c|c|c|c|}
\hline $\begin{array}{c}\text { Clone } \\
92-23\end{array}$ & $\begin{array}{c}\text { TRIAL \# } \\
231 \\
215 \\
226\end{array}$ & $\begin{array}{c}\text { DAY } 4 \\
97 \\
99 \\
99 \\
98.33\end{array}$ & $\begin{array}{c}\text { DAY } 8 \\
90 \\
89 \\
88 \\
89.00\end{array}$ & $\begin{array}{c}\text { DAY } 12 \\
82 \\
77 \\
64 \\
74.33\end{array}$ & $\begin{array}{c}\text { DAY } 16 \\
81 \\
71 \\
52 \\
68.00\end{array}$ & $\begin{array}{c}\text { DAY } 20 \\
64 \\
61 \\
29 \\
51.33\end{array}$ & $\begin{array}{c}\text { DAY } 24 \\
52 \\
49 \\
23 \\
41.33\end{array}$ & $\begin{array}{c}\text { DAY } 28 \\
49 \\
49 \\
18 \\
38.67\end{array}$ & $\begin{array}{c}\text { DAY } 32 \\
45 \\
45 \\
12 \\
34.00\end{array}$ \\
\hline $92-30$ & $\begin{array}{l}199 \\
193 \\
194\end{array}$ & $\begin{array}{c}100 \\
54 \\
100 \\
84.67\end{array}$ & $\begin{array}{c}100 \\
31 \\
96 \\
75.67\end{array}$ & $\begin{array}{c}93 \\
17 \\
82 \\
64.00\end{array}$ & $\begin{array}{c}88 \\
7 \\
72 \\
55.67\end{array}$ & $\begin{array}{c}85 \\
3 \\
62 \\
50.00\end{array}$ & $\begin{array}{c}80 \\
2 \\
54 \\
45.33\end{array}$ & $\begin{array}{c}75 \\
2 \\
51 \\
42.67\end{array}$ & $\begin{array}{c}65 \\
1 \\
47 \\
37.67\end{array}$ \\
\hline $92-45$ & $\begin{array}{l}197 \\
194 \\
193\end{array}$ & $\begin{array}{c}100 \\
100 \\
99 \\
99.67\end{array}$ & $\begin{array}{c}100 \\
96 \\
84 \\
93.33\end{array}$ & $\begin{array}{c}99 \\
94 \\
-64 \\
85.67\end{array}$ & $\begin{array}{r}97 \\
91 \\
60 \\
82.67\end{array}$ & $\begin{array}{c}90 \\
87 \\
56 \\
77.67\end{array}$ & $\begin{array}{c}83 \\
88 \\
56 \\
75.67\end{array}$ & $\begin{array}{c}69 \\
78 \\
52 \\
66.33\end{array}$ & $\begin{array}{c}67 \\
73 \\
48 \\
62.67\end{array}$ \\
\hline $92-48$ & $\begin{array}{l}215 \\
201 \\
231\end{array}$ & $\begin{array}{c}100 \\
100 \\
100 \\
100.00\end{array}$ & $\begin{array}{c}90 \\
96 \\
93 \\
93.00\end{array}$ & $\begin{array}{c}80 \\
92 \\
86 \\
86.00\end{array}$ & $\begin{array}{c}74 \\
90 \\
79 \\
81.00\end{array}$ & $\begin{array}{c}71 \\
87 \\
53 \\
70.33\end{array}$ & $\begin{array}{c}61 \\
74 \\
47 \\
60.67\end{array}$ & $\begin{array}{c}59 \\
68 \\
42 \\
56.33\end{array}$ & $\begin{array}{c}55 \\
56 \\
35 \\
48.67\end{array}$ \\
\hline $2-183$ & $\begin{array}{l}214 \\
211 \\
229\end{array}$ & $\begin{array}{c}100 \\
100 \\
96 \\
98.67\end{array}$ & $\begin{array}{c}100 \\
99 \\
80 \\
93.00\end{array}$ & $\begin{array}{c}97 \\
97 \\
67 \\
87.00\end{array}$ & $\begin{array}{c}94 \\
83 \\
64 \\
80.33\end{array}$ & $\begin{array}{c}80 \\
82 \\
36 \\
66.00\end{array}$ & $\begin{array}{c}73 \\
79 \\
32 \\
61.33\end{array}$ & $\begin{array}{c}64 \\
65 \\
27 \\
52.00\end{array}$ & $\begin{array}{c}53 \\
47 \\
17 \\
39.00\end{array}$ \\
\hline MEAN & $\begin{array}{l}214 \\
226 \\
211\end{array}$ & $\begin{array}{c}100 \\
96 \\
100 \\
98.67\end{array}$ & $\begin{array}{c}99 \\
83 \\
92 \\
91.33\end{array}$ & $\begin{array}{c}90 \\
64 \\
79 \\
77.67\end{array}$ & $\begin{array}{c}81 \\
39 \\
75 \\
65.00\end{array}$ & $\begin{array}{c}90 \\
19 \\
67 \\
58.67\end{array}$ & $\begin{array}{c}90 \\
10 \\
66 \\
55.33\end{array}$ & $\begin{array}{c}82 \\
7 \\
62 \\
50.33\end{array}$ & $\begin{array}{c}78 \\
5 \\
57 \\
46.67\end{array}$ \\
\hline $2-194$ & $\begin{array}{l}214 \\
229 \\
211\end{array}$ & $\begin{array}{c}100 \\
100 \\
100 \\
100.00\end{array}$ & $\begin{array}{c}99 \\
98 \\
100 \\
99.00\end{array}$ & $\begin{array}{c}92 \\
86 \\
99 \\
92.33\end{array}$ & $\begin{array}{c}88 \\
71 \\
90 \\
83.00\end{array}$ & $\begin{array}{c}87 \\
63 \\
82 \\
77.33\end{array}$ & $\begin{array}{c}85 \\
56 \\
72 \\
71.00\end{array}$ & $\begin{array}{c}80 \\
50 \\
63 \\
64.33\end{array}$ & $\begin{array}{c}72 \\
40 \\
55 \\
55.67\end{array}$ \\
\hline $2-261$ & $\begin{array}{c}224 \\
228 \\
\star \star\end{array}$ & $\begin{array}{c}100 \\
98\end{array}$ & $\begin{array}{l}96 \\
97\end{array}$ & $\begin{array}{l}89 \\
94\end{array}$ & $\begin{array}{l}89 \\
90\end{array}$ & $\begin{array}{l}76 \\
89\end{array}$ & $\begin{array}{l}78 \\
86\end{array}$ & $\begin{array}{l}65 \\
66\end{array}$ & $\begin{array}{l}64 \\
58\end{array}$ \\
\hline MEAN & & 99.00 & 96.50 & 91.50 & 89.50 & 82.00 & 82.00 & 65.00 & 61.00 \\
\hline $2-310$ & $\begin{array}{l}330 \\
222 \\
220\end{array}$ & $\begin{array}{c}99 \\
100 \\
100 \\
99.67\end{array}$ & $\begin{array}{c}87 \\
97 \\
99 \\
94.33\end{array}$ & $\begin{array}{c}74 \\
79 \\
96 \\
83.00\end{array}$ & $\begin{array}{c}80 \\
72 \\
92 \\
81.33\end{array}$ & $\begin{array}{c}51 \\
61 \\
85 \\
65.67\end{array}$ & $\begin{array}{c}24 \\
57 \\
77 \\
52.67\end{array}$ & $\begin{array}{c}20 \\
56 \\
67 \\
47.67\end{array}$ & $\begin{array}{c}3 \\
55 \\
64 \\
40.67\end{array}$ \\
\hline Overall & & 97.52 & 91.79 & 82.86 & 76.64 & 67.53 & 61.73 & 54.79 & 48.16 \\
\hline
\end{tabular}




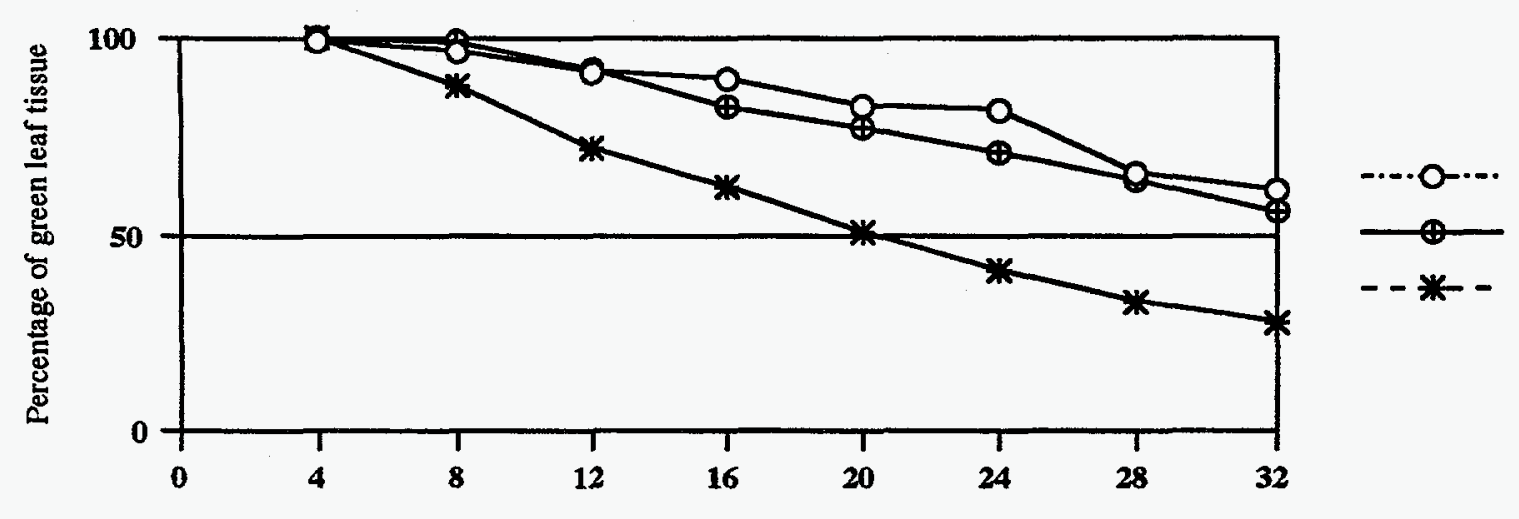

Somaclone 92-261

Somaclone 92-194

NE 308 - Donor plants $(N=36)$

Days after inoculation with S. Musiva

Somaclone "92-310"

Leaf Disk Results

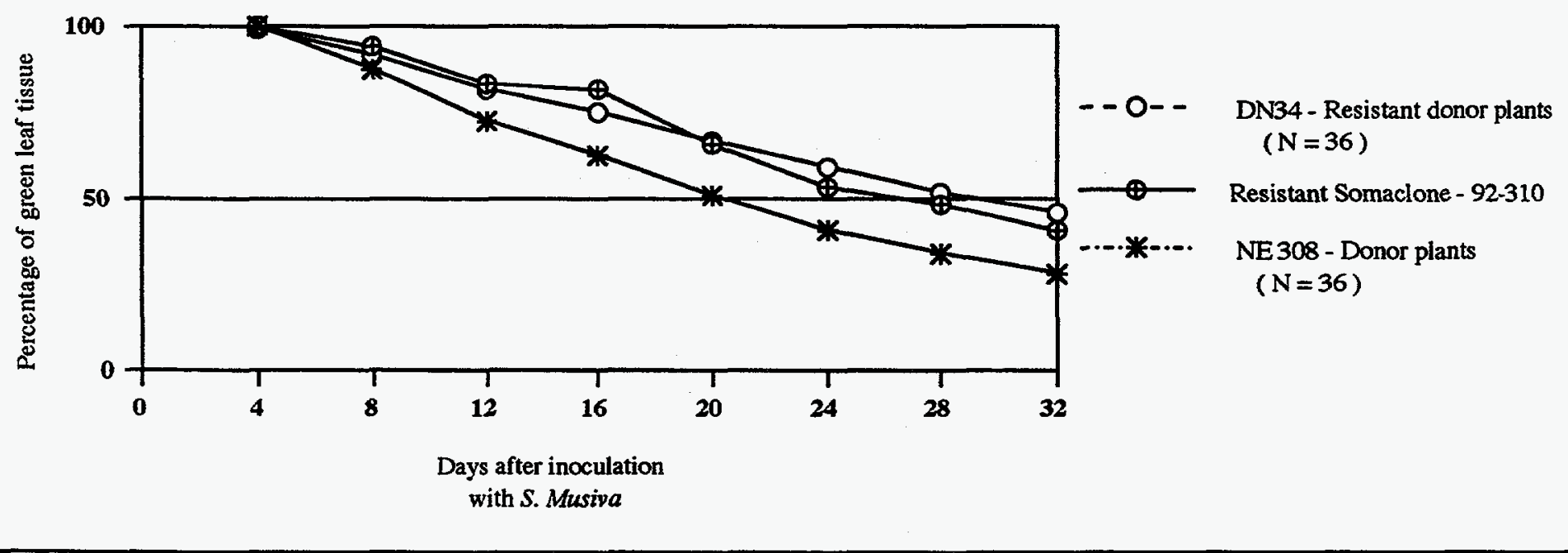

\section{Grand Mean - Resistant Somaclones}

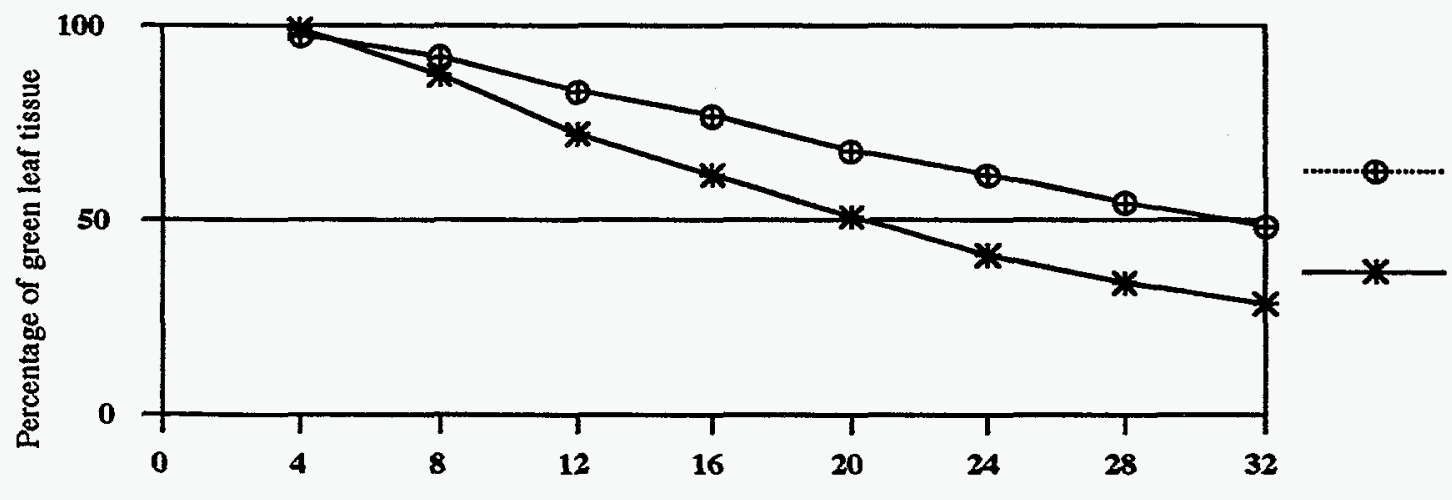

Resistant NE 308 Somaclones $(\mathrm{N}=36)$

NE308 - Donor Plants

$(\mathrm{N}=36)$

Days after inoculation with S. Musiva 
NE 299 Somaclone Planting, Rosemount Minnesota

Ranked by Growth and Disease Resistance

Data Collected Fall, 1994

Clone Diam. Height D2H Septoria Cankers Live Marss. Winter Best $(\mathrm{cm})(\mathrm{cm})(\mathrm{cm} 2)$ Leaf* per Tree Trees Survival Leaft Iniu

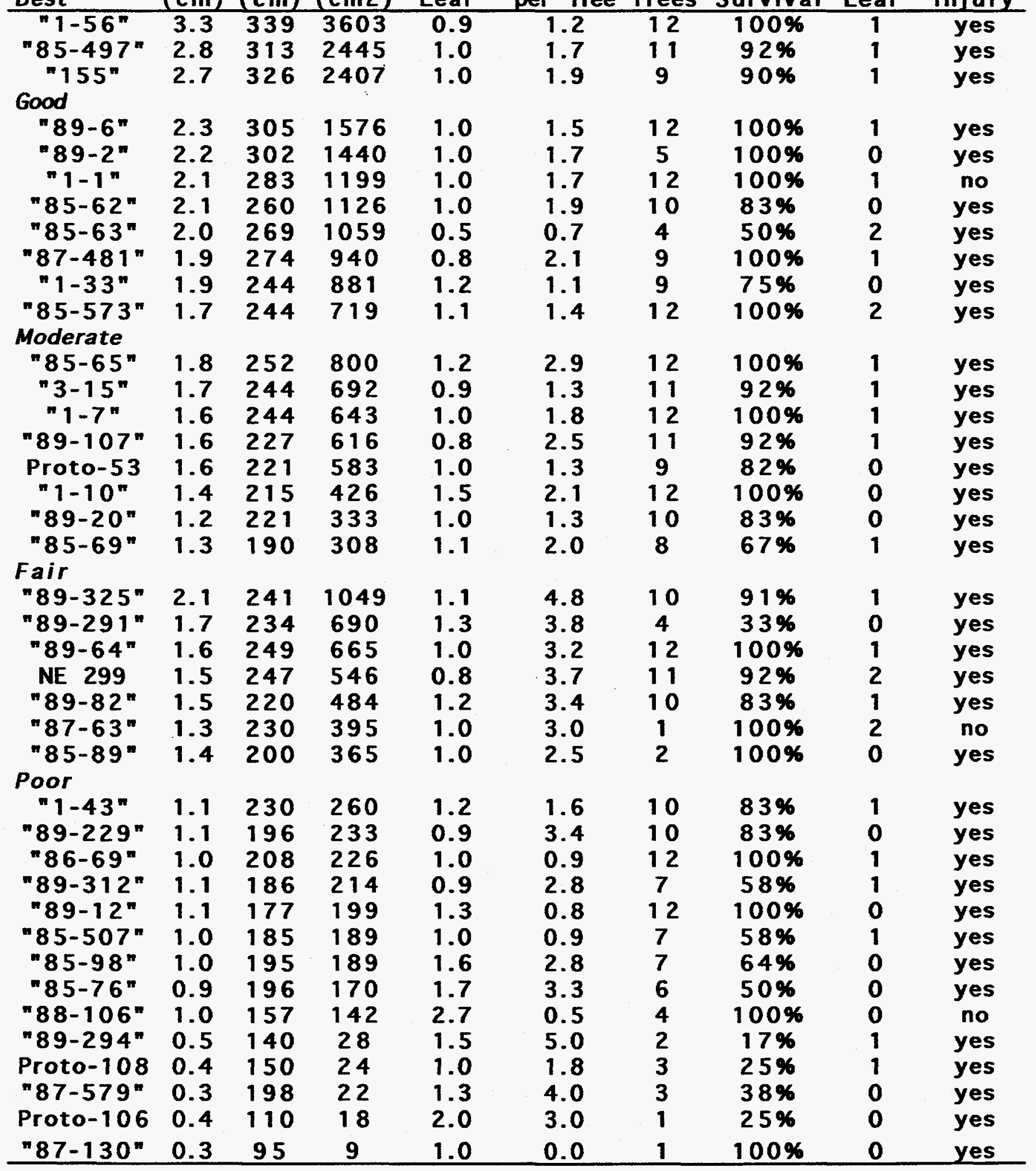

*.0 =absent; 1 =slight, 1 to $25 \%$ crown affected; 2 =moderate, 26 to $75 \% ; 3=$ severe,76 to $100 \%$. 


\section{INTERNAL DISTRIBUTION}

1. M. A. Brown

2-21. L. S. Cooper

22. J. H. Cushman

23. M. E. Downing

24. A. R. Ehrenshaft

25. R. L. Graham

26. S. G. Hildebrand

27. S. B. McLaughlin

28. W. A. McNabb

29. A. C. Schaffhauser
30. V. R. Tolbert

31. G. A. Tuskan

32. M. E. Walsh

33. L. L. Wright

34. Central Research Library

35. ESD Library

36-37. Laboratory Records Dept.

38. Laboratory Records, ORNL-RC

39. ORNL Patent Section

40. ORNL Y-12 Technical Library

\section{EXTERNAL DISTRIBUTION}

41. W. E. Berguson, University of Minnesota, Natural Resources Research Institute, 5013 Miller Trunk Highway, Duluth, MN 55811

42. J. B. Birk, EPRI, P O Box 10412, Palo Alto, CA 94303

43. T. Bradshaw, University of Washington, Ctr. for Urban Horticulture, GF15, Seattle, WA 98195

44. D. H. Dawson, 3015 S. River Road, P.O. Box 1321, Rhinelander, WI 54501

45. D. I. Dickmann, Michigan State University, Dept. of Forestry, 125 Natural Resources, East Lansing, MI 48824-1222

46. J. E. Ferrell, U.S. Department of Energy, Biofuels Systems Division, CE 331 Forrestal Bldg., 5F-034, Washington, DC 20545

47. S. Gronich, U.S. Department of Energy, CE-132, 5H-059, Forrestal Building, 1000 Independence Ave., SW, Washington, DC 20585

48. R. B. Hall, Iowa State University, Forestry Dept., 251 Bessey Hall, Ames, IA 50011

49. E. A. Hansen, 2411 County Road 1A, Montrose, CO 81401

50. P. E. Heilman, Washington State University, W. Washington Res. \& Extension Center, Puyallup, WA 98371

51. T. Hinckley, University of Washington, College of Forest Resources, Seattle, WA 98195

52. Evan Hughes, Electric Power Research Institute, P.O. Box 10412, Palo Alto, CA 94303

53. J. G. Isebrands, USDA Forest Service, Forestry Sciences Laboratory, 5985 Highway K, Rhinelander, WI 54501

54. T. Kroll, Minnesota Dept. of Natural Resources, Forestry Division, 500 Lafayette Road, St. Paul, MN 55155-404412 
55. F. J. Kuzel, Great Lakes Regional Biomass Energy Prg, Council of Great Lakes Governors, 35 E. Wacker Drive, Suite 1850, Chicago, IL 60601

56. S. B. Land, Jr., Mississippi State University, Dept. of Forestry, P.O. Drawer FR, 900 America's Center Bldg., Mississippi State, MS 39762

57. G. Larson, WesMin Resource Conservation and Development Council, 910 Highway 29 North \#103, Alexandria, MN 56308-5012

58-67. D. Netzer, USDA Forest Service, North Central Forest Exp. Station, Forestry Sciences Laboratory, 5985 Highway K, Rhinelander, WI 54501

68. Tien Nguyen, U.S. Department of Energy, Office of Fuels Development, 1000 Independence Avenue, S.W., EE-331, Washington, DC 20585-0121

69. L. D. Ostlie, Energy Performance Systems, 4900 N. Hwy. 167, Suite 303, Minneapolis, MN 55428

70-74. M. E. Ostry, USDA Forest Service, North Central Forest Experiment Station, 1992 Folwell Ave., St. Paul, MN 55108

75. J. Preece, Southern Illinois University, Dept. of Plant \& Soil Science, Carbondale, IL 62901

76. D. Riemenschneider, USDA Forest Service, Forestry Sciences Laboratory, 5985 Highway K, Rhinelander, WI 54501

77. S. Sprague, U.S. Dept. of Energy, Biofuels Systems Division, CE 331 Forrestal Bldg., Washington, DC 20545

78. J. H. Turnbull, Electric Power Research Institute, Storage and Renewables Department, P O Box 10412, Palo Alto, CA 94303

79. A. Wiselogel, National Renewable Energy Laboratory, 1617 Cole Blvd., Golden, CO 80401

80-81. Office of Scientific and Technical Information, P.O. Box 62, Oak Ridge, TN 37831 